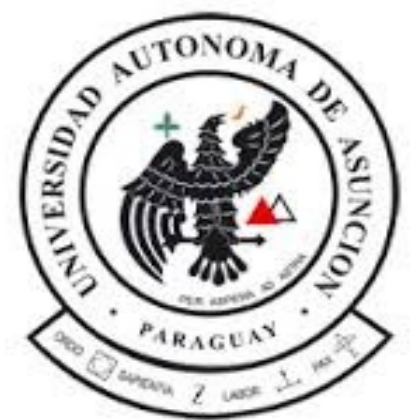

UNIVERSIDAD AUTÓNOMA DE ASUNCIÓN

FACULTAD CIENCIAS JURÍDICAS, POLITICAS Y DE LA COMUNICACIÓN

DOCTORADO EN CIENCIAS DE LA EDUCACIÓN

ANÁLISE DAS CONTRIBUIÇÕES DAS TIC À APRENDIZAGEM

MATEMÁTICA DOS ALUNOS DAS ESCOLAS MUNICIPAIS DE CAMPINA

GRANDE-PB

FLAVIANO AGUIAR SILVA 
FLAVIANO AGUIAR SILVA

\section{ANÁLISE DAS CONTRIBUIÇÕES DAS TIC À APRENDIZAGEM MATEMÁTICA DOS ALUNOS DAS ESCOLAS MUNICIPAIS DE CAMPINA \\ GRANDE-PB}

Tese presentada al Curso de Pos Grado de la Facultad de Ciencias Humanísticas como requisito final a la obtención del título de Doctor en Ciencias de la Educación.

Orientador: Prof. Dr. Luiz Ortiz Jimenez 


\section{FICHA CATALOGRÁFICA}

Silva, F. A. (2019). Análise das contribuições das tic à aprendizagem matemática dos alunos das escolas municipais de Campina Grande-PB. Flaviano Aguiar Silva, 2019. (p. 137)

Orientador: Prof. Dr. Luiz Ortiz Jimenez

Tesis de Doctorado. Universidad Autónoma de Asunción, Facultad Ciencias Jurídicas, Políticas y de la Comunicación Doctorado en Ciencias de la Educación, Asunción. Paraguay. 2019.

Palabras-clave: Tecnologías Educativas, Enseñanza-aprendizaje, Matemática, práctica-pedagógica, Innovación. 


\section{Flaviano Aguiar Silva}

\section{ANÁLISE DAS CONTRIBUIÇÕES DAS TIC À APRENDIZAGEM MATEMÁTICA DOS ALUNOS DAS ESCOLAS MUNICIPAIS DE CAMPINA GRANDE-PB}

Orientador: Prof. Dr. Luiz Ortiz Jimenez

Esta tese fue evaluada y aprobada en

para a obtención del título de Doctor en Ciencias de la Educación por la Universidad Autónoma de Asunción - UAA

\section{Asunción - Paraguay}

2019 
Dedico esta dissertação À minha esposa Jô pela compreensão e paciência durante minha trajetória acadêmica; A minha mãe, fonte de amor, tranquilidade e perseverança; Aos meus filhos, Flávia e Flaviano Filho pelos momentos de descontração e alegria proporcionados; Aos netos Luan Flávio e Lorran Felipe; Aos eternos e saudosos pai - Antônio, filho - Flávio, irmão - Tião; Aos meus colegas, professores e funcionários do curso. 


\section{AGRADECIMENTOS}

Tenho que agradecer primeiro a Deus por me guiar, dar forças e tranquilidade para seguir em frente, só Ele para fazer com que meus objetivos e anseios não caíssem no fosso do esquecimento e tornassem realidade.

A minha família que compreenderam e respeitaram minha ausência em momentos que seria de suma importância para o elo familiar, mas, mesmo assim sempre me motivaram, entenderam as minhas faltas e me apoiaram nos momentos difíceis e brindaram a cada etapa conquistada;

Agradeço aos amigos das aulas de Doutorado que por tantas vezes entenderam as dificuldades enfrentadas por nós. A Alexandre e Ivana In memorian eternas saudades sempre estarão conosco;

Agradecimento especial ao Doutor Ismael Sousa por dispensar seu tempo passando-me suas recomendações e ideias para a solidificação do desse trabalho;

Ao professor Doutor Francisco de Assis Batista, Diretor Adjunto do Centro de Educação (CEDUC-UEPB) que confiou e deu forças para continuar a jornada e consolidar meu trabalho;

A professora Doutora Waltimar Batista Rodrigues Lula, Coordenadora do curso de Sociologia (UEPB) que sempre me passou tranquilidade e estímulo em função do meu projeto;

A professora Mestre Maria José Silva Oliveira Aposentada do curso de História (UEPB), a quem tenho imenso respeito e admiração, ela que foi a principal incentivadora enquanto chefe de Departamento para solidificação e inicio das minhas práticas e ideais;

Ao Professor Doutor Luis Ortiz Jimenez meu Orientador, a sua dedicação e disponibilidade e às suas recomendações, muito obrigado! E ainda tive a satisfação de participar de algumas corridas ao seu lado nas ruas de Assunção - Paraguai.

Agradeço aos professores e Alunos das Escolas nas quais desenvolvi o trabalho, atores fundamentais para o seu desenvolvimento e conclusão, meu muito obrigado as secretárias e aos gestores que me receberam de forma tão agradável e amiga, sem vocês com certeza ainda estaria caminhando com a pesquisa;

As Secretárias do Postgrado da Universidad Autónoma de Asunción - PY que tantas vezes me esclareceram e conduziram as instancias necessárias para resolução de situações tão complicadas; 
Por fim agradeço a todos que fizeram parte da minha vida nessa jornada, acreditando que tudo é possível basta seguir em frente e buscar. 
A educação é um processo social, é desenvolvimento. Não é a preparação para a vida, é a própria vida.

John Dewey 


\section{SUMÁRIO}

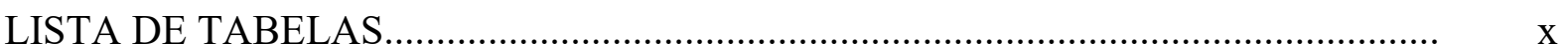

LISTA DE QUADROS....................................................................................

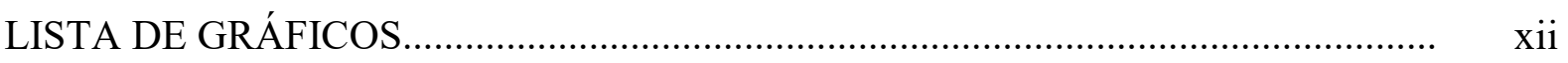

LISTA FIGURAS........................................................................................... xiv

LISTA DE ABREVIATURAS...................................................................

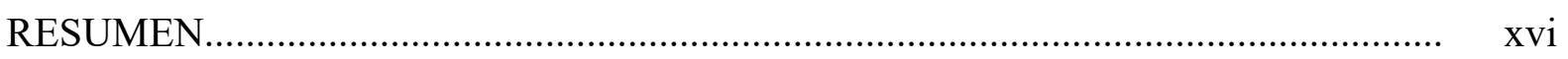

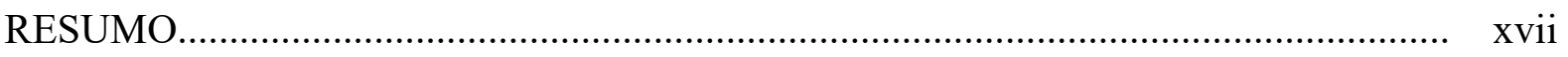

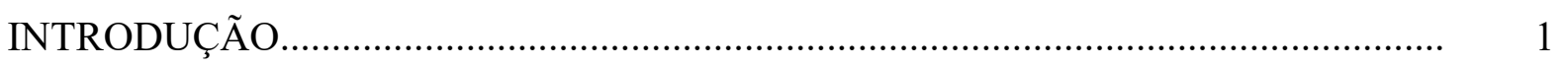

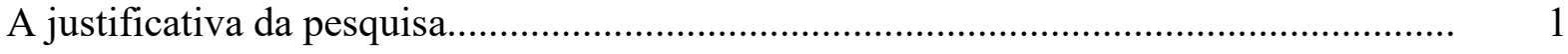

Problema da pesquisa...........................................................................................

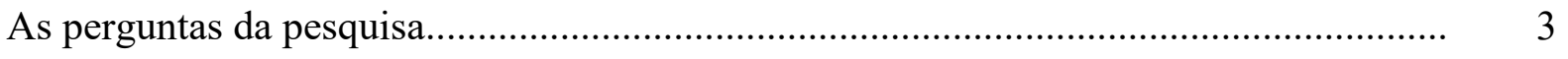

Os Objetivos da Pesquisa....................................................................................

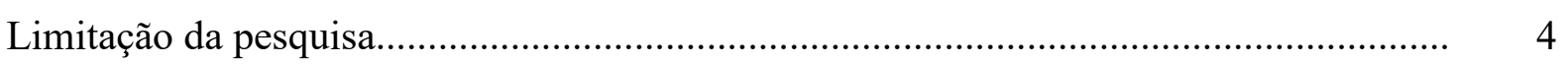

Instrumentos usados na pesquisa..............................................................................

Relevância da pesquisa...........................................................................................

Estrutura da pesquisa..........................................................................................

1. A EVOLUÇÃO DA INFORMÁTICA NO CONTEXTO EDUCACIONAL... 6

2. A IMPLANTAÇÃO DA INFORMÁTICA NA EDUCAÇÃO.......................... 11

$2.1 \quad \mathrm{O}$ avanço da informática nas escolas.............................................................. 12

3. O USO PEDAGÓGICO DAS TECNOLOGIAS NA ESCOLA COMO PRÁTICAS INOVADORAS........................................................................... 15

4. O ENSINO DA MATEMÁTICA MEDIADO PELAS TIC............................... 22

4.1. Recursos Tecnológicos usados no auxilio do aprendizado de matemática........ 24

5. A INFLUÊNCIA DAS TIC NO DESENVOLVIMENTO DO APRENDIZADO DOS ALUNOS................................................................ 34

5.1. Alunos nativos digitais............................................................................. 37

5.2. As TIC favorecendo a interação entre o aprendiz e o aprendizado..................... 38

5.3. O valor da interação professor/alunos no EA de Matemática........................... 42

5.4. O uso pedagógico das mídias na escola como práticas inovadoras.................... 47 
6. MARCO METODOLÓGICO............................................................... 52

6.1. O Problema da pesquisa..................................................................... 52

6.2. As perguntas da pesquisa.................................................................. 53

6.3. Os Objetivos da Pesquisa...................................................................... 53

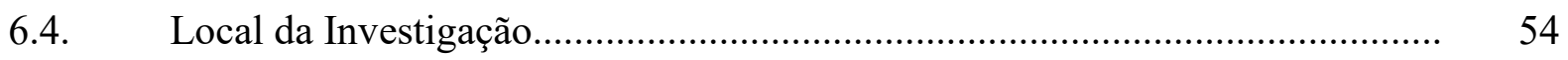

6.4.1. Histórico da Cidade de Campina Grande, Paraíba, Brasil.............................. 54

6.4.2. A Instituição Escolar............................................................................ 56

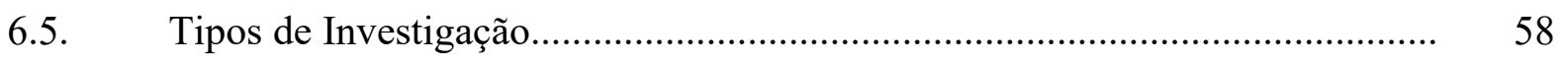

6.6. População e Amostra da pesquisa................................................................... 59

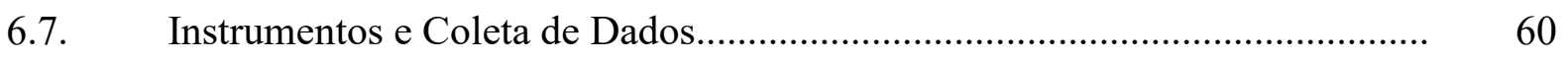

6.8. Procedimentos para Coletas de Dados............................................................ 62

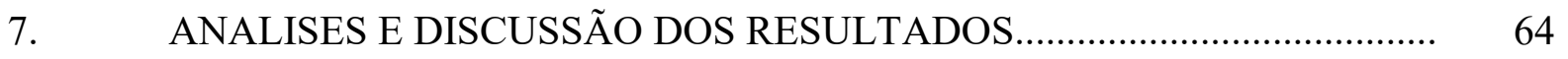

7.1. Dados sobre os participantes (sujeitos) da pesquisa........................................ 64

7.2. Analises dos resultados do questionário aplicado aos alunos........................... 69

7.3. Analises dos resultados do questionário aplicado aos professores................... 79

7.4. Discussão dos resultados da pesquisa......................................................... 88

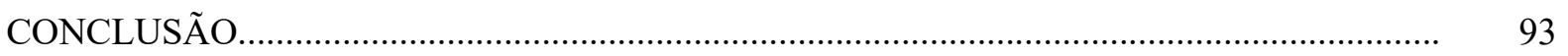

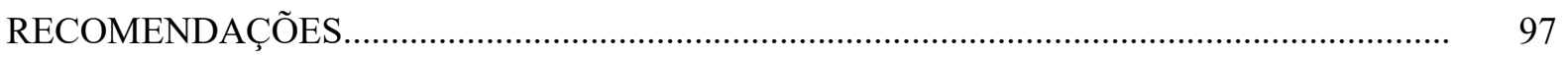

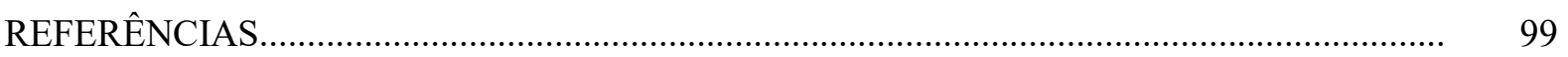

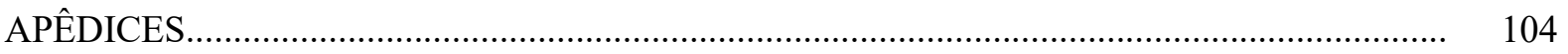

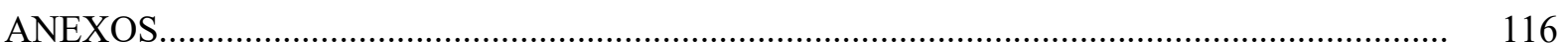




\section{LISTA DE TABELAS}

TABELA 01 Quantitativo de Escolas com computadores e acesso à Internet período 1999/2003 .................................................................... 13

TABELA 02 População e amostra dos alunos que participarão da pesquisa.......... 59

TABELA 03 Tabela da Primeira Variável.............................................................. 61

TABELA 04 Perfil dos professores da Escola Municipal Lafayete Cavalcante município de Campina Grande, Paraíba, Brasil.

TABELA 05 Perfil dos alunos da Escola Municipal Lafayete Cavalcante município de Campina Grande, Paraíba, Brasil.

TABELA 06 Perfil dos professores da Escola Municipal Manoel da Costa Cirne, Campina Grande, Paraíba, Brasil......................................... 67

TABELA 07 Perfil dos alunos da Escola Municipal Manoel da Costa Cirne, Campina Grande, Paraíba, Brasil....................................................... 68 


\section{LISTA DE QUADROS}

QUADRO 01 Enfoque Construtivista do Processo de Aprendizagem............. 38

QUADRO 02 Ações do professor e necessidades dos alunos............................. 43 


\section{LISTA DE GRÁFICOS}

GRÁFICO 01 Como você se sente quando o professor usa as TIC nas aulas de matemática?

GRÁFICO 02 Como você ver as aulas de matemática quando o professor usa os recursos tecnológicos para ensinar os conteúdos?

GRÁFICO 03 O professor tem usado muito as TIC para ensinar os conteúdos em sala de aula?

GRÁFICO 04 As aulas de matemática se tornaram mais interessantes com o uso dos recursos tecnológicos pelo seus professor?

GRÁFICO 05 As atividades de matemática ministradas por meios dos Recursos Tecnológicos têm melhorado seu desempenho no aprendizado dos conteúdos?

GRÁFICO 06 Você se sente mais estimulado com o uso dos recursos tecnológicos no auxílio das atividades de matemática?

GRÁFICO 07 Com a inclusão do uso da TIC nas aulas de matemáticas você tem percebido avanço no aprendizado?

GRÁFICO 08 As aulas de matemática ficaram mais atraentes com o uso dos recursos tecnológico pelo seu professor (a)?

GRÁFICO 09 O professor sempre incentiva a classe usar mais as TIC para melhorar o aprendizado dos conteúdos de matemática?

GRÁFICO 10 O uso das TIC tem mudado seu interesse pelo aprendizado da disciplina de matemática?.

GRÁFICO 11 Você tem conhecimento da potencialidade do uso das TIC no ensino dos conteúdos de matemática?

GRÁFICO 12 As TIC possibilita potencialidade a pratica pedagógica no ensinoaprendizado de matemática favorecendo o rendimento acadêmico dos seus alunos?.

GRÁFICO 13 Tem usado os recursos tecnológicos como apoio ao ensino-aprendizado nas aulas de matemática?

GRÁFICO 14 Tem notado a diferença no rendimento acadêmico dos seus alunos quando usa as TIC como apoio ao ensino-aprendizado dos conteúdos de matemática em sala de aula?.

GRÁFICO 15 A escola em que trabalha tem disponibilizado de laboratório de informática 
para você com seus alunos realizarem atividades usando os recursos tecnológicos?

GRÁFICO 16 O uso de aplicativos como jogos virtuais interativos como: Desafio Matemático, Matemática para Crianças, Perguntas de Matemática, Caça Palavras Matemática etc. Nas aulas de matemática motivam os alunos a socializar conhecimentos entre si durante as aulas?

GRÁFICO 17 Com o uso das TIC reforçando o aprendizado de matemática. Seus alunos tem melhorado o índice de aprovação na disciplina?

GRÁFICO 18 O uso das TIC tem dado mais dinamicidade as suas aulas tem levado os alunos a se interessarem mais pelo aprendizado dos conteúdos de matemática?

GRÁFICO 19 Você gostaria de ter mais capacitação relacionado ao uso das TIC para melhor desenvolver seu trabalho com os alunos em sala de aula? 


\section{LISTA DE FIGURA}

FIGURA 01 Primeiro Computador do Mundo "The Witch"......................... 6

FIGURA 02 Jogo: Matemática para criança.................................................. 26

FIGURA 03 Jogo: Desafio Matemático Grátis................................................ 26

FIGURA 04 Jogo, Perguntas de Matemática................................................... 28

FIGURA 05 Jogo, Perguntas de Matemática 2 ............................................... 28

FIGURA 06 Jogo, Matemática para Crianças................................................... 29

FIGURA 07 Jogo Mestre da Matemática......................................................... 30

FIGURA 08 Aplicativo Cola Matemática........................................................ 31

FIGURA 09 Aplicativo MathYou................................................................ 31

FIGURA 10 Aplicativo Rei da Matemática.................................................... 32

FIGURA 11 Localização da cidade de Campina Grande no mapa da Paraíba, Brasil............................................................................... 54

FIGURA 12 Vista aérea 1 de Campina Grande, Paraíba, Brasil........................ 55

FIGURA 13 Vista aérea 2 de Campina Grande, Paraíba, Brasil........................ 56

FIGURA 14 Faixada da Escola Municipal Manoel da Costa Cirne................... 57

FIGURA 15 Faixada da Escola Municipal Lafayete Cavalcante................ 57 


\section{LISTA DE ABREVIATURAS}

$\begin{array}{ll}\text { App } & \text { Aplicativos } \\ \text { AVAs } & \text { Ambiente Virtual de Aprendizagem } \\ \text { EA } & \text { Ensino-aprendizado } \\ \text { LDB } & \text { Lei de Diretrizes e Bases da Educação Nacional } \\ \text { MEC } & \text { Ministério de Educação e Cultura } \\ \text { PROINFO } & \text { Programa Nacional de Tecnologia Educacional } \\ \text { QI } & \text { Quociente de Inteligência } \\ \text { TIC } & \text { Tecnologias Informática e comunicação }\end{array}$




\section{RESUMEN.}

Esta investigación de doctorado surgió a partir de la necesidad de Analizar las Contribuciones de las TIC al aprendizaje de matemática de los alumnos de las escuelas municipais de Campina Grande-Paraíba, Brasil. Visto la gran carencia de los investigadores de la región nordeste aun no se profundizaren en línea de investigaciones con esa temática. El Objetivo General de la investigación es determinar la manera como ha mejorado el desempeño de los alumnos de las Escuelas Municipais Lafayete Cavalcante y Manoel da Costa Cirne que estudian matemática utilizando las TIC. Los objetivos específicos son: 1)Estimar la diferencia en el rendimiento académico de los alumnos que tienen acceso a las TIC a los que no tiene acceso; 2) Verificar se el índices de aprobación y reemplazo puede ser influenciado por el uso de las TIC en las escuelas; y 3) Establecer se los alumnos se sienten más estimulados a estudiar matemática utilizando las TIC. La metodología presenta un enfoque cuantitativo, del tipo descriptiva, el muestreo es probabilística simples, el instrumento utilizado fue el cuestionario cerrado aplicado a los profesores y alumnos. Algunos teóricos que se fundamento la investigación: Assmann, (2000, 2005); Citelli e Costa (2011); D’ambrósio, (1996); Demo, (2004); Lima, e Silva, (2012); Machado, (2002); Marconi e Lakatos, (2009); Mason, (1996); Oliveira, (2007); Silva,. (2015). Se pretende concientizar críticamente los profesores, a la gestión de la instituciones, a la Secretaria de Educación y investigadores o licenciados en el área de la educación que tengan acceso a esta investigación sobre la necesidad de implementar y utilizar adecuadamente el aula de informática, pero considerando que es necesario para tal la formación continuada específica del equipo de profesores así como la implementación de un plan de acción específico en el área.

Palabras-claves: Tecnologías de la Información comunicación; Enseñanza-aprendizaje; matemática; práctica-pedagógica; innovación. 


\section{RESUMO.}

Está pesquisa de doutorado surgiu a partir da necessidade de Analisar as Contribuições das TIC à aprendizagem matemática dos alunos das escolas municipais de Campina GrandeParaíba, Brasil. Visto a grande carecia dos pesquisadores da região nordeste ainda não se aprofundarem em linhas de pesquisas com essa temática. O Objetivo Geral da pesquisa é determinar a forma como melhorou o desempenho dos alunos das Escolas Municipais Lafayete Cavalcante e Manoel da Costa Cirne que estudam matemática utilizando as TIC. Os objetivos específicos são: 1)Estimar a diferença no rendimento acadêmico dos alunos que têm acesso às TIC aos que não têm acesso; 2) Verificar se índices de aprovação e reprovação pode ser influenciado pelo uso das TIC nas escolas; e 3) Estabelecer se os alunos se sentiram mais estimulados a estudar matemática utilizando as TIC. A metodologia apresenta um enfoque quantitativo, do tipo descritiva, o tipo de amostra é probabilística simples, o instrumento utilizado foi o questionário fechado aplicado para os a professores e alunos. Alguns teóricos que se fundamentou a pesquisa: Assmann, (2000, 2005); Citelli e Costa (2011); D’ambrósio, (1996); Demo, (2004); Lima, e Silva, (2012); Machado, (2002); Marconi e Lakatos, (2009); Mason, (1996); Oliveira, (2007); Silva,. (2015). Pretende-se conscientizar criticamente os professores, à gestão da instituição, à Secretaria de Educação e pesquisadores ou licenciados na área da educação que tenham acesso a esta pesquisa sobre a necessidade de implementar e utilizar adequadamente a sala de informática, mas considerado que é necessário para tal a formação continuada específica da equipe de professores assim como a implementação de um plano de ação específico na área.

Palavras-chaves: Tecnologias da Informação e comunicação; Ensino-aprendizado; matemática; prática-pedagógica; inovação. 


\section{INTRODUÇÃO}

$\mathrm{Na}$ atualidade as TIC vêm revolucionando a vida da sociedade em todos os seus contextos existentes como o: familiar, lazer, trabalho, e principalmente na educação. As TIC tem entrado na vida da sociedade de uma maneira poderosa levando o desenvolvimento e informações a sociedade na base de um simples toque( dados eletrônicos adquiridos por aparelhos sofisticados como o celular inteligente com "tela touch”).

Segue alguns autores que trabalharam sobre a temática TIC, trabalhos publicados mais recentes sobre o tema: a) Raquel Goulart Barreto - As tecnologias na política nacional de formação de professores a distância: entre a expansão e a redução. Campinas-SP (Ano de publicação 2008); b) Cleder Tadeu Antão da Silva - A formação continuada de professores nas políticas públicas de inclusão das tecnologias da informação e comunicação da educação básica: um estudo de caso sobre o projeto “escolas em rede”, da SEE-MG. (Ano de publicação 2009); c) Suênia Izabel Lino MolinNovas tecnologias na educação: transformações da prática pedagógica no discurso do professor. Itajaí- SC (Ano de publicação 2010).

A justificativa da pesquisa

O processo de transformações e revoluções que marcam a sociedade contemporânea e coage a escola, e especialmente o docente, a repensar constantemente seu dinamismo e desempenho em sala de aula. Mesmo com essas mudanças, e com os instrumentos tecnológico existente na escola que facilita a vida do docente, muitos não sabem como trabalhar em sala de aula ou manuseá-lo. E ao mesmo tempo não são incentivados a usá-los.

Consequências da pesquisa: pretende-se conscientizar criticamente os professores, à gestão da instituição, à Secretaria de Educação e pesquisadores ou formandos na área da 
educação que tenham acesso a esta pesquisa sobre a necessidade de programar e utilizar adequadamente a sala de informática, mas considerado que é necessário para tal a formação continuada específica da equipe de professores assim como a implementação de um plano de ação específico na área.

Embora o impacto da utilização da sala de informática na escola seja um tema amplamente debatido no meio científico educacional Moreira (2012) comenta que a pesquisa em educação brasileira ainda está restrita aos grupos de pesquisa e pouco impacto tem na realidade da educação. Pesquisar dentro da instituição, para a instituição e o sistema de ensino local é uma oportunidade que permite que os resultados sejam analisados e posteriormente sirvam como parâmetro para melhorias do processo educativo conforme as necessidades reais de cada objeto de pesquisa.

Tanto para a instituição quanto para a Secretaria de Educação do Município de Campina Grande, Paraíba, pesquisadores da área de educação e formação docente estes dados sustentarão projetos de formação docente e de ampliação dos recursos tecnológicos na escola para melhorar o processo ensino-aprendizagem tornando-o mais dinâmico, atrativo para os alunos.

As informações requeridas para a pesquisa serão obtidas com a secretaria das escolas com autorização da Secretaria de Educação do Município de Campina Grande. Da mesma forma se conta com os recursos humanos, técnicos e financeiros para a realização da mesma.

Avaliação das deficiências no conhecimento do problema. Embora o impacto da utilização da sala de informática na escola seja um tema amplamente debatido no meio científico educacional Moreira (2012) comenta que a pesquisa em educação brasileira ainda está restrita aos grupos de pesquisa e, o impacto que tem na realidade da educação. Pesquisar dentro da instituição, para a instituição e o sistema de ensino local é uma oportunidade que permite que os resultados sejam analisados e posteriormente sirvam como parâmetro para melhorias do processo educativo conforme as necessidades reais de cada objeto de pesquisa. 
O Problema da pesquisa

As Escolas Municipais Lafayete Cavalcante e Manoel da Costa Cirne, situadas no município de Campina Grande/PB, contam com 625 alunos e 38 professores em 18 salas de aula distribuídos nos turnos matutino, vespertino e noturno. As instituições contam com sala de informática com computadores com acesso a internet. Durante a pesquisa realizada por Silva (2015) foi constatado que o uso do laboratório de informática contribui para o desenvolvimento de habilidades e competências matemáticas dos alunos. No entanto, não há uma forma de determinar quantitativa nem qualitativamente a contribuição das TIC no ensino.

Diante de este contexto surge a pergunta que orienta a presente investigação: houve melhoria no desempenho dos alunos das Escolas Municipais Lafayete Cavalcante e Manoel da Costa Cirne que estudam matemática utilizando as TIC?

As perguntas da pesquisa

As Perguntas Especificas da pesquisa são: 1) Como Estimar a diferença no rendimento acadêmico dos alunos que têm acesso às TIC aos que não têm acesso?; 2) De que maneira verificar se índices de aprovação e reprovação pode ser influenciado pelo uso das TIC nas escolas? 3) Como estabelecer se os alunos se sentiram mais estimulados a estudar matemática utilizando as TIC?

Os Objetivos da Pesquisa

O Objetivo General da pesquisa é: Determinar a forma como melhorou o desempenho dos alunos das Escolas Municipais Lafayete Cavalcante e Manoel da Costa Cirne que estudam matemática utilizando às TIC.

Os Objetivos Específicos da pesquisa são: 1) Estimar a diferença no rendimento acadêmico dos alunos que têm acesso às TIC aos que não têm acesso; 2) Verificar se índices de aprovação e reprovação pode ser influenciado pelo uso das TIC nas escolas; 3) 
Estabelecer se os alunos se sentiram mais estimulados a estudar matemática utilizando as TIC.

\section{A Limitação da pesquisa}

Sobre as limitações da pesquisa: por contar com o apoio e aprovação da instituição de ensino e da Secretaria de Educação local e os dados encontram-se disponíveis no sistema eletrônico SIGEPA não se considera que haja limitações ou dificuldades para o desenvolvimento da pesquisa.

Os Instrumentos usados na pesquisa

Os de instrumentos utilizados foram a entrevista estruturada e questionários fechado que foram aplicados aos professore e alunos participantes da pesquisa.

\section{A Relevância da pesquisa}

Por outra parte, a pesquisa é relevante pois ao seu âmbito, esta pesquisa abrirá novos caminhos para investigadores que apresentem situações similares a que surge aqui, servindo como quadro referencial para futuras pesquisa sobre a temática.

A presente pesquisa ampliará os resultados obtidos por Silva (2015) permitindo ter informações mais abrangentes sobre o uso dos recursos tecnológicos no ensino da matemática podendo comparar os resultados relativos ao rendimento acadêmico dos alunos da referida escola e demostrando como o uso da sala de informática é importante e que interfere diretamente nos resultados tanto de rendimento acadêmico quanto dos índices de aprovação e reprovação. 
A Estrutura da pesquisa

A pesquisa está constituída de 9 (nove) Capítulos que são: Capítulo I- A evolução da informática no contexto educacional; Capítulo II - A implantação da informática na Educação; Capítulo III - O uso pedagógico das tecnologias na escola como práticas inovadoras; Capítulo IV- O ensino da matemática mediado pelas TIC; Capítulo V- A influência das TIC no desenvolvimento do aprendizado dos alunos; Capítulo VI- Marco metodológico; Capítulo VII- Analises e discussão dos resultados; Capítulo VIIIConclusões e Capítulo IX- Recomendações. 


\section{A EVOLUÇÃO DA INFORMÁTICA NO CONTEXTO EDUCACIONAL}

Na década de 70, havia grandes discursos sobre o perigo das máquinas dominarem os humanos e, em particular, dos computadores e calculadoras tornarem as crianças apáticas. Neste sentido, Segundo Borba (2012) dever-se-ia evitar que os alunos fossem contagiados pelos processos mecânicos das mídias informatizadas. No final desta década, quando teve início a discussão sobre o uso de tecnologia da informática na educação, imaginava-se que uma das implicações de sua inserção nas escolas seria o desemprego de professores, ou seja, muitos deles temiam ser substituídos pela máquina.

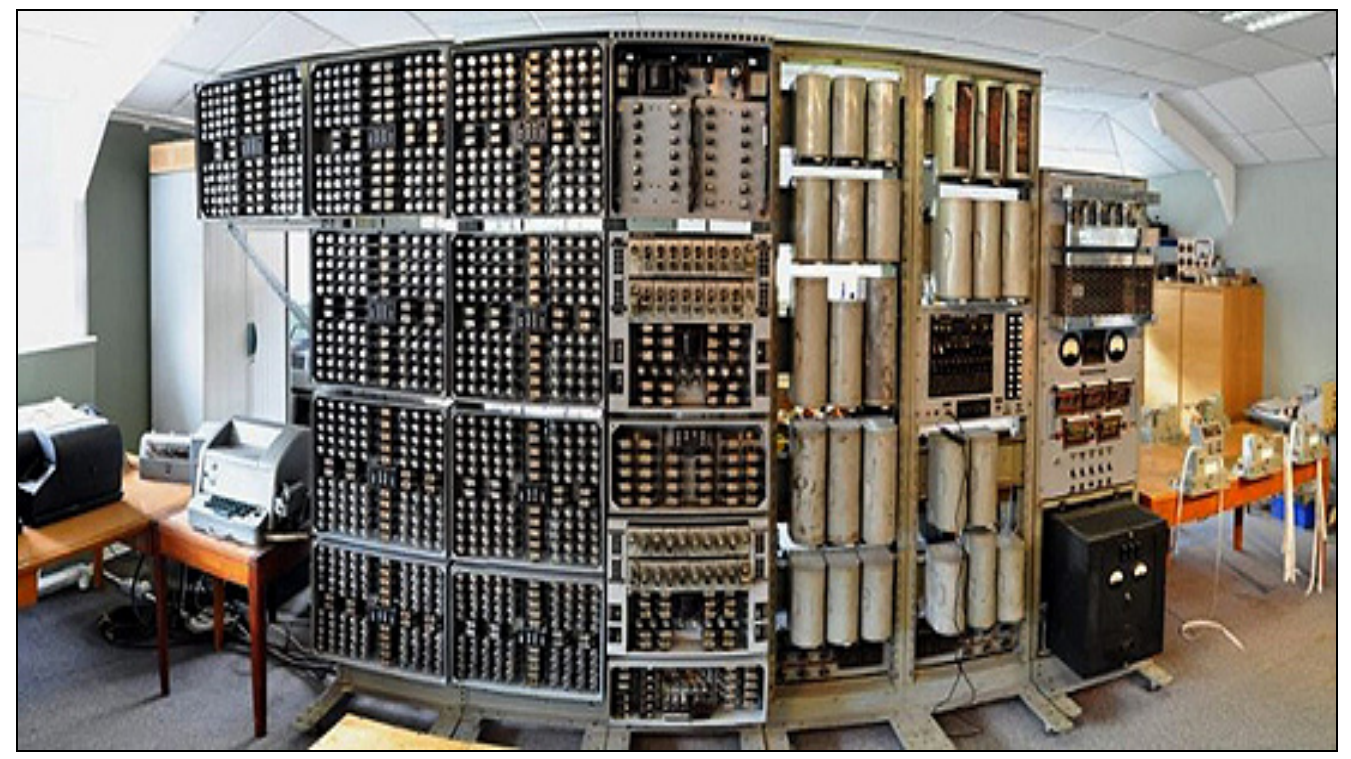

Figura 01: Primeiro Computador do Mundo "The Witch".

Fonte: http://www1.folha.uol.com.br/tec/1188459-primeiro-computador-do-mundo-e-religado-em-museu-nainglaterra.shtml

Segundo a Folha (2012), nos anos de 1950, durante seus dias de glória, "The Witch", cuja a construção começou em 1949, foi a peça central do programa britânico de Pesquisa de Energia Atômica. Sua missão era facilitar o trabalho dos cientistas realizando 
de forma eletrônicas operações matemáticas que até então deviam ser feitas por meio de simples máquinas de calcular. Apesar da lentidão de seus primeiros trabalhos, demorava dez segundos para multiplicar 2 números, em breve se tornou em peça indispensável e chegou a ser usado 80 horas semanais, um recorde para a época.

Como pode-se ver o computador na sua primeira aparição já foi usado para facilitar a vida dos profissionais usando a matemática. Facilitou a vida dos cientistas que precisavam com mais rapidez fazer seus cálculos e avançar em suas pesquisas.

Já no final dos anos 80 e início dos anos 90, a informática e educação tem sido tema de discussões no Brasil e no mundo. Porém, surgem algumas preocupações daqueles que defendem a não adequação do uso de computadores na escola, ou simplesmente a utilização de tecnologia de informática na escola. Quem defende esse argumento parece não considerar que haja acesso difundido à informática nas escolas públicas.

Por outro lado, existem argumentos favoráveis sobre a implantação dos computadores na escola. Pois essa ferramenta pode ser um problema a mais na vida já atribulada do professor, mais segundo Citelli (2011) pode também desencadear o surgimento de novas possibilidades para o seu desenvolvimento como um profissional na educação, adequando-se aos novos métodos e práticas que a informática proporciona aos professores, estes por sua vez terão uma nova forma de transmitir conhecimento.

Outro argumento, Almeida (2000) dá ênfase à importância do uso da informática em educação para preparar o jovem para o mercado de trabalho. Pois, quem possui tal conhecimento na área está bem preparado, e tem mais facilidade de conseguir empregos do que alguém que não consegue ligar o computador e trabalhar com alguns aplicativos básicos. Nesse contexto, a informática tem sido a vilã do desemprego no País e no mundo.

Nas escolas públicas e particulares, o acesso à informática deve ser visto como um direito do estudante de usufruir dessa educação como alfabetização tecnológica, e não apenas como um curso de informática.

A grande evolução sociocultural e tecnológica do mundo atual gera muitas mudanças nas organizações e no pensamento humano, revelam um novo universo no 
cotidiano das pessoas, exigindo independência, criatividade e autocrítica na obtenção e na seleção de informações, assim como na construção do conhecimento.

Para Machado (2002), o emprego da tecnologia computacional está promovendo a aquisição de novos conhecimentos e o desenvolvimento de diferentes modos de representação e compreensão do pensamento, o que possibilita representar novas ideias e hipóteses, levando a criação de um mundo abstrato e simbólico, que ao mesmo tempo introduzem diferentes formas de atuação e integração entre as pessoas.

Existe certa euforia em relação à utilização da tecnologia em todos os ramos da atividade humana, não excluindo o sistema educacional. Entretanto, as propostas de modernização da educação em sua maioria não têm alcançado o sucesso esperado ao enfrentar tais questões.

Na história da evolução tecnológica, o primeiro revolucionário foi Comrius (1592 1670), quando transformou o livro impresso em ferramenta de ensino e de aprendizagem, com a invenção da cartilha e do livro-texto. Tinha como ideia utilizar esses instrumentos para viabilizar um novo caminho, voltado para a universalização do ensino.

Necessita-se no âmbito educacional de uma proposta de parcerias entre o setor educacional e a comunidade, para explorar e construir conhecimentos segundo suas necessidades. Pois segundo Almeida:

A verdadeira função do aparato educacional não deve ser a de ensinar, mas sim a de criar condições de aprendizagem. Isso significa que o professor precisa deixar de ser o separador de conhecimento - o computador pode fazer isso e o faz muito mais eficiente do que o professor - e passar a ser o criador de ambientes de aprendizagem e o facilitador do processo de desenvolvimento intelectual do aluno. (Almeida, 2000; p. 15-16).

A partir deste novo contexto de transformações e de novas exigências em relação ao aprender, o que não exigem a adoção de métodos diversificados, mas sim de atitudes diante do conhecimento e da aprendizagem, bem como uma nova concepção de educação em nossa sociedade. Isto significa que o professor terá papeis diferentes a desempenhar, o que torna necessário novos modos de formação que possam prepará-lo para o uso 
pedagógico do computador, assim como para refletir sobre a sua prática e durante a sua prática, acerca do desenvolvimento, da aprendizagem e de seu papel de agente transformador de si mesmo e de seus alunos que, segundo Almeida leva a um

(...) aprendizado de um novo referencial educacional envolvendo mudanças de mentalidade, mudanças de valores, concepções, ideias, e consequentemente de atitudes, não é um ato mecânico. É um processo reflexivo, depurativo, de reconstrução, que implica em transformação, e transformar significa conhecer. (Almeida, 2000; p. 16).

Desta forma, tem que se considerar a formação do professor que reflete uma questão fundamental em um processo de formação. Na tentativa de construir com o desafio de encontrar caminhos que possibilitem formar professores para utilizarem os recursos do computador de acordo com uma abordagem reflexiva.

A aprendizagem já é percebida como a interação entre os conhecimentos que o aluno já tem e os novos conhecimentos adquiridos na escola, sendo que essa interação propiciará a construção de outros conhecimentos, por isso, a participação do aluno em sala de aula durante as atividades apresenta um número maior de frequência quando existe alguma proposta de interação entre o conteúdo e algum ambiente multimídia que o leve a autoria, pois um ambiente virtual que o estimule a construir seu conhecimento tem uma contribuição bem maior no processo de aprendizagem.

Segundo Barreto (2009) A aposta nas TIC, nas condições em que tem sido produzida, pode se confundir com a centrada nos materiais ditos "auto instrucionais", para usar uma expressão cara ao tecnicismo dos anos de 1970. Concebidos como autoexplicativos, dispensam a mediação pedagógica propriamente dita. No máximo, requerem tutores que permitam aos "clientes" tirar dúvidas derivadas das "suas" dificuldades de leitura.

As TIC por si só não tem o mesmo êxito de quando ela é direcionada pelo professor que está capacitado a trabalhar com ela junto a seus alunos. As TE para serem bem usadas pelos alunos depende por parte da orientação do professor, do auxilio para que assim os 
alunos possam ter um norte de como trabalhar as atividades especificas e obterem o êxito esperado. 


\section{A IMPLANTAÇÃO DAS TIC NA EDUCAÇÃO}

Ao refletir à questão da inclusão digital, necessita-se relembrar a exigência que provocou no final do século XX, um movimento mundial, "a inserção na sociedade da informação, que favorecendo uma corrida para a construção de políticas nacionais", (Jambeiro, Lima e Brandão, 2005; p. 8), o que veio refletir na educação abrindo um novo caminho para quem não tem familiaridade ou capacitação para manusear os recursos tecnológicos.

Desta forma, seguindo este movimento no Brasil, a LDB 9394/96 em seu art. 2 ressalta "a educação tem por finalidade desenvolver o educando, assegurar-lhe a formação comum e indispensável para o exercício da cidadania e fornecer-lhe meios para progredir no trabalho e em estudos posteriores" (BRASIL, 1996; apud, Pessoa, 2005; p. 20), o que propicia a utilização de novos meios para se alcançar uma educação qualitativa, assim se introduz na educação a era digital no qual os computadores e seus derivados passam a exercer papel de destaque no mundo moderno.

A informática inserida na educação traz como perspectiva o manuseio e utilização dos recursos digitais que concorrem de maneira positiva para a educação, caracterizando-se pelo uso do computador como ferramenta para resolução de problemas, antes desconhecidos pelos educandos. O que leva o professor de matemática "projetar desafios que estimulem o questionamento, a colocação de problemas e a busca de solução. Os alunos não se tornam ativos aprendizes por acaso, mas por desafios projetados e estruturados, que visem à exploração e investigação" (Kampff, Machado \& Cavedine, 2003; p. 2).

Neste contexto, cabe à escola, em parceria com a sociedade fazer do jovem um cidadão mais reflexivo e adaptado às rápidas mudanças que a tecnologia vem impondo à vida moderna. A educação permanente será uma das formas de promover o contínuo 
aperfeiçoamento e as adequações necessárias às novas alternativas de ocupação profissional (Gaeta, 2007; p. 78).

É essencial que as escolas disponibilizem para o aluno estruturas necessárias para que ele se sinta confortável a aprender e se familiarizar com o computador, o que pressupõe uma transformação essencial no processo de aprendizagem, renovando os meios de aquisição do conhecimento propiciando uma nova visão ao educando.

\subsection{O avanço da informática nas escolas}

A educação no Brasil ainda se encontra muito inflexível, com cargas horárias, calendários, conteúdos preestabelecidos que visivelmente impedem que o aluno estimule a criatividade, a reflexão e a descoberta das novas tecnologias. É necessário implantar nas crianças e adolescentes a necessidade do aprendizado da informática, de forma que o aprender se torne menos maçante. As crianças se encantam rapidamente pelos computadores e suas cores, sons e imagens, o que torna o seu uso atrativo.

A realidade da educação no Brasil está longe de ser a ideal para o novo contexto educacional: as escolas ainda se encontram precariamente equipadas para a chamada inclusão digital.

É claro que estamos passando por um desenvolvimento, o que demanda tempo e investimentos altos em equipamentos, no treinamento e atualização dos profissionais da educação.

O projeto do PROINFO na sua implantação previa o gasto de US\$ 500 milhões para a compra de 100 mil computadores e a criação de 200 NTE3 espalhados pelo país para servirem de provedores de acesso à Internet e centrais de treinamento próximas às escolas e aos educadores; incluía a formação de mil multiplicadores, em nível de especialização, para capacitar 25 mil professores das escolas onde foram implantados os computadores (Brasil, 1997; p. 87). 
Todas essas iniciativas demonstram o interesse do governo federal em tornar a escola compatível com a atualidade e fazer com que a sociedade caminhe lado a lado das mudanças tecnológicas que estão ocorrendo no cenário mundial. Implantando o parque de informática, treinando profissionais para lidar com a tecnologia abrindo um leque de possibilidades para atrair a atenção dos alunos com o apelo audiovisual que a informática permite e com a disseminação da cultura tecnológica - aliando a tecnologia, a rapidez da informação ao contexto sociocultural da escola; de forma que o computador seja, assim como o quadro-negro e o giz partes intrínsecas da escola.

De acordo com a tabela abaixo, percebemos o crescimento do número de computadores nas escolas e o aumento de escolas com acesso à Internet, demonstrando o interesse do governo federal em ampliar o parque de informática das escolas.

Tabela 01: Quantitativo de Escolas com computadores e acesso à Internet período 1999/2003.

\begin{tabular}{ccc}
\hline Ano & Escolas com Microcomputadores & Escolas com Acesso à Internet \\
\hline 1999 & 17.918 .109 & 3.127 .135 \\
\hline 2000 & 19.456 .663 & 6.704 .784 \\
\hline 2001 & 20.830 .012 & 8.960 .512 \\
\hline 2002 & 22.640 .892 & 10.474 .309 \\
\hline 2003 & 23.894 .517 & 11.645 .251 \\
\hline
\end{tabular}

Fonte: MEC/INEP.

Os professores devem fazer sempre cursos de reciclagem, pois a tecnologia está em constante desenvolvimento; os computadores precisam de manutenções e atualizações e não se pode correr o risco de todo esse investimento ser perdido com máquinas sucateadas e educadores desatualizados - trata-se de um processo contínuo, tendo em vista que os computadores fazem parte do dia a dia das escolas e são ferramentas fundamentais para o ensino de qualidade e preparado para o futuro.

Há alguns anos atrás, os instrumentos utilizados pelos professores para proporcionar ao aluno uma aula interessante era somente o quadro negro, giz e suas explanações verbais. Em raras exceções havia alguma ferramenta metodológica que tornasse a aula mais dinâmica. Hoje, os docentes dispõem de uma gama de recursos que 
tornam as aulas mais agradáveis e com boa assimilação dos conteúdos por parte dos educandos.

Dentre estes recursos, destacam-se os laboratórios de informática que integram o educando a uma nova etapa do processo educacional, considerado pela pedagogia moderna como básica para o exercício da cidadania, pois segundo Citelli (2011) com o desenvolvimento das tecnologias digitais muitos serviços, público ou privado, só podem ser realizados através da rede mundial de computadores, o que torna muitos indivíduos excluídos do acesso às atividades produtivas.

O uso da tecnologia na educação é um tema que já se discute a partir das três últimas décadas no Brasil e há mais tempo em outros lugares do mundo. Muitos educadores preocupados com essa discussão ressaltam os perigos que a informática poderia trazer para a aprendizagem dos alunos, como: eles estão apenas apertando teclas e obedecendo às orientações proporcionadas pela máquina tornando-os ainda mais meros repetidores de tarefas.

Tal argumento está presente quando se considera a educação de modo geral, mas é ainda mais poderoso dentro de parte da comunidade de educação matemática. Em especial para aqueles que concebem a matemática como matriz do pensamento lógico. Neste sentido se o raciocínio matemático passa a ser pelo computador, o aluno não precisará raciocinar mais e deixará de desenvolver sua inteligência (Borba \& Penteado, 2012, p. 1).

Acima de tudo faz-se necessário uma reflexão sobre a educação matemática auxiliada pela informática como uma transformação na prática educativa e possibilidade para o desenvolvimento do professor como um novo profissional da educação.

Já que os laboratórios existem em várias escolas vemos a educação matemática como um direito do estudante poder usufruir de uma educação que o torne um alfabetizado tecnológico, o que não é meramente fazer um curso de informática e sim, como ler e utilizar esse novo instrumento, que a partir de então deverá estar inserido nas atividades do educando. 


\section{O USO PEDAGÓGICO DAS TIC NA ESCOLA COMO PRÁTICAS INOVADORAS}

Ao longo dos anos a mudança em torno da tecnologia tem conseguido uma profundidade veloz. Tendo em vista que a tecnologia tem mostrado grande importância no desenvolvimento da sociedade, é necessário que a escola também se insira nessa revolução tecnológica, pois os alunos já fazem parte de uma geração totalmente integrada ao mundo das mídias, daí a mudança na prática do professor para que possa ofertar ao aluno uma educação apropriada para o uso consciente e reflexivo das tecnologias.

O trabalho com a tecnologia exige do professor uma nova forma de educar, pois a revolução da tecnologia acontece independentemente de estar ou não em um planejamento da escola, pois os alunos que já convivem com essa tecnologia inovadora em seu cotidiano já sentem a necessidade de que escola desenvolva seu trabalho partindo dela.

Assmann (2005), afirma que:

“As novas tecnologias da informação e da comunicação já não são meros instrumentos no sentido técnico tradicional, mas feixes de propriedades ativas. É algo tecnologicamente novo e diferente. As tecnologias tradicionais serviam como instrumentos para aumentar o alcance dos sentidos (braço, visão, movimento, etc.). As novas tecnologias ampliam o potencial cognitivo do ser humano (seu cérebro/mente) e possibilitam mixagens cognitivas complexas e cooperativas.” (Assmann, 2005, p.18).

Com isso, é necessário que seja ampliada a visão que o professor tem sobre o uso das novas tecnologias em sala de aula. Não basta para eles apenas utilizar mecanicamente as ferramentas tecnológicas, mas também, saber para que deve usar, como usar e que impacto terá na aprendizagem do aluno. 
Hoje quando um aluno tem dúvida ele não pergunta mais ao professor, pergunta ao Google à inteligência virtual, isso demonstra que estamos vivendo em uma nova era e a escola precisa fazer parte, oferecendo a essa nova geração inclusão digital através de atividades que a leve a ser produtor e divulgador do conhecimento. Para que essa inclusão seja efetivada é preciso romper com estruturas arcaicas que impossibilitam o professor a vislumbrar as possibilidades de inovação da sua prática, superando o receio das tecnologias digitais.

A tecnologia se apresenta com o objetivo de inovar a prática docente, atribuir significado a essa prática e garantir a expansão da aula real em um momento virtual, unificando o presencial e o ensino a distância, deixando as tarefas de casa mais criativas e agradáveis de serem feitas.

A pedagogia de projetos é uma oportunidade que a escola encontra para introduzir tecnologia na sala de aula. Esses projetos precisam de tempos maiores que os projetos escolares, precisam ser mais dinâmicos, criativos e que leve o aluno a perfazer o trajeto da autoria, para não se tornar um mero repetidor de conhecimentos já elaborados. Os projetos precisam conduzir os alunos para coisas que eles precisam saber, proporcionando um ambiente virtualmente interativo para que ele possa sentir-se estimulado a participar e criar. Os projetos atuais apenas se preocupam em transmitir conteúdos disciplinares, transferir conhecimentos, mas isso não basta para o aluno que está nas salas de aula.

Segundo Ferreira e Frade (2009) a educação emergente da sociedade informacional aponta para um novo paradigma educativo no qual a linha de construção do saber é centrada no "sujeito coletivo", que saiba reconhecer a importância do "outro" junto ao processo construtor e multiplicador do conhecimento.

O paradigma da educação midiática requer uma revisão emergente do processo de "ensinar" e "aprender", bem como também uma gestão consciente da pedagogia e do "conhecimento em rede".

As tecnologias educativas configuram-se como produtos sociais e culturais da era da informação, que, por sua vez, acabam por interferir na subjetividade e esquemas imaginários para sua concretização. 
Ferreira e Frade (2009) explica que esta cultura midiática acaba por sua vez por propiciar uma recriação da realidade, demarcando sutilmente a barreira existente entre o virtual $\mathrm{X}$ o real, onde a imagem se torna o próprio objeto e não uma mera forma de representação deste.

Para Machado (2002), o emprego das TIC está promovendo a aquisição de novos conhecimentos e o desenvolvimento de diferentes modos de representação e compreensão do pensamento, o que possibilita representar novas ideias e hipóteses, levando a criação de um mundo abstrato e simbólico, que ao mesmo tempo introduzem diferentes formas de atuação e integração entre as pessoas. Ao refletir à questão da inclusão digital, necessita-se relembrar a exigência que provocou no final do século XX, um movimento mundial, "a inserção na sociedade da informação, que favorecendo uma corrida para a construção de políticas nacionais", (Jambeiro, Lima e Brandão, 2005; p. 8), o que veio refletir na educação abrindo um novo caminho para quem não tem familiaridade ou capacitação para manusear os recursos tecnológicos.

Desta forma, seguindo este movimento no Brasil, a LDB 9394/96 em seu art. 2 ressalta "a educação tem por finalidade desenvolver o educando, assegurar-lhe a formação comum e indispensável para o exercício da cidadania e fornecer-lhe meios para progredir no trabalho e em estudos posteriores" (BRASIL, 1996, apud, PESSOA, 2005, p. 20), o que propicia a utilização de novos meios para se alcançar uma educação qualitativa, assim se introduz na educação a era digital no qual os computadores e seus derivados passam a exercer papel de destaque no mundo moderno.

Behaviorismo, cognitivismo e construtivismo são as três grandes teorias da aprendizagem mais frequentemente usadas na criação de ambientes instrucionais. Essas teorias, contudo, foram desenvolvidas em um tempo em que a aprendizagem não sofria o impacto da tecnologia. Através dos últimos vinte anos, a tecnologia reorganizou o modo como vivemos, como nos comunicamos e como aprendemos.

Para Vaill (1996) as necessidades de aprendizagem e teorias que descrevem os princípios e processos de aprendizagem, devem refletir o ambiente social vigente. Enfatiza também que "a aprendizagem deve ser um modo de ser - um conjunto usual de atitudes e 
ações que pessoas e grupos empregam para tentar se manter a par dos eventos surpreendentes, novos, confusos, perturbadores que aparecem sempre".

É claro que estamos passando por um desenvolvimento, o que demanda tempo e investimentos altos em equipamentos, no treinamento e atualização dos profissionais da educação.

A inclusão da tecnologia e do fazer conexões como atividades de aprendizagem dão inicio para mover as teorias da aprendizagem para uma idade digital. Não podemos mais, pessoalmente, experimentar e adquirir a aprendizagem de que necessitamos para agir. Nós alcançamos nossa competência como resultado da formação de conexões. Kleiner (2002, apud Stephenson) coloca:

"A experiência tem sido considerada, há muito tempo, o melhor professor para o conhecimento. Desde que não podemos experimentar tudo, as experiências de outras pessoas e, portanto, outras pessoas, tornam-se o substituto para o conhecimento. 'Eu guardo meu conhecimento em meus amigos`é um axioma para juntar conhecimento juntando pessoas”. (p.3).

Segundo a teoria do conectivismo de Siemens (2004) o conectivismo é a integração de princípios explorados pelo caos, rede, e teorias da complexidade e autoorganização. A aprendizagem é um processo que ocorre dentro de ambientes nebulosos onde os elementos centrais estão em mudança - não inteiramente sob o controle das pessoas. A aprendizagem (definida como conhecimento acionável) pode residir fora de nós mesmos (dentro de uma organização ou base de dados), é focada em conectar conjuntos de informações especializados, e as conexões que nos capacitam a aprender mais são mais importantes que nosso estado atual de conhecimento.

Os princípios do conectivismo:

- Aprendizagem e conhecimento apoiam-se na diversidade de opiniões.

- Aprendizagem é um processo de conectar nós especializados ou fontes de informação.

- Aprendizagem pode residir em dispositivos não humanos. 
- A capacidade de saber mais é mais crítica do que aquilo que é conhecido atualmente.

- É necessário cultivar e manter conexões para facilitar a aprendizagem contínua.

- A habilidade de enxergar conexões entre áreas, ideias e conceitos é uma habilidade fundamental.

- Atualização (“currency” - conhecimento acurado e em dia) é a intenção de todas as atividades de aprendizagem conectivistas.

- A tomada de decisão é, por si só, um processo de aprendizagem. Escolher o que aprender e o significado das informações que chegam é enxergar através das lentes de uma realidade em mudança. Apesar de haver uma resposta certa agora, ela pode ser errada amanhã devido a mudanças nas condições que cercam a informação e que afetam a decisão.

Como cita Siemens (2004) o conectivismo também trata das mudanças que muitas corporações encontram nas atividades de gestão do conhecimento. O conhecimento que fica em uma base de dados precisa ser conectado com as pessoas certas nos contextos certos para que possam ser classificadas como aprendizagem. O behaviorismo, cognitivismo e construtivismo não se referem aos desafios do conhecimento e transferência organizacionais.

Vale ressaltar que o ponto de partida do conectivismo é o indivíduo. O conhecimento pessoal é composto por uma rede que alimenta as organizações e instituições, que por sua vez alimenta de volta a rede e então continua a prover aprendizagem para o indivíduo. Este ciclo de desenvolvimento do conhecimento (da pessoa para a rede para a organização) permite que os aprendizes se mantenham atualizados em seus campos, através das conexões que formaram.

Assim como argumenta Moran (2000 apud Santiago, 2006; p.11): As novas tecnologias permitem ampliar o conceito de aula, de espaço e tempo, estabelecer pontes novas entre o presencial e o virtual, entre o estar juntos e o estarmos conectados a distância. Porém, o desafio na educação é muito maior do que simplesmente a utilização de 
recursos tecnológicos, o importante é refletir uma educação com tecnologia que possa ser oferecida com qualidade.

A ocasião em que estamos vivendo marcada pela ciência e tecnologia que provoca a cada instante transformação no jeito de sentimento e atuação do docente. Isso vem provocando grandes mudanças na área da educação. Que nasce mudanças de colapso de modelos da qual a escola é obrigada a adaptar-se a essa nova tecnologia.

Todas essas iniciativas demonstram o interesse do governo federal em tornar a escola compatível com a atualidade e fazer com que a sociedade caminhe lado a lado das mudanças tecnológicas que estão ocorrendo no cenário mundial. Implantando o parque de informática, treinando profissionais para lidar com a tecnologia abrindo um leque de possibilidades para atrair a atenção dos alunos com o apelo audiovisual que a informática permite e com a disseminação da cultura tecnológica - aliando à tecnologia, à rapidez da informação ao contexto sociocultural da escola; de forma que o computador seja, assim como o quadro-negro e o giz partes intrínsecas da escola.

Desta forma são inseridos os laboratórios de informática que integram o educando a uma nova etapa do processo educacional, considerado pela pedagogia moderna como básica para o exercício da cidadania, pois segundo Citelli (2011) com o desenvolvimento das tecnologias digitais muitos serviços, público ou privado, só podem ser realizados através da rede mundial de computadores, o que torna muitos indivíduos excluídos do acesso às atividades produtivas.

O trabalho com a tecnologia exige do professor uma nova forma de educar, pois a revolução da tecnologia acontece independentemente de estar ou não em um planejamento da escola, pois os alunos que já convivem com essa tecnologia inovadora em seu cotidiano já sentem a necessidade de que escola desenvolva seu trabalho partindo dela.

Segundo a afirmativa a seguir:

As novas tecnologias da informação e da comunicação já não são meros instrumentos no sentido técnico tradicional, mas feixes de propriedades ativas. É algo tecnologicamente novo e diferente. As tecnologias tradicionais serviam como instrumentos para aumentar o alcance dos sentidos (braço, visão, movimento, etc.). As novas tecnologias ampliam o 
potencial cognitivo do ser humano (seu cérebro/mente) e possibilitam mixagens cognitivas complexas e cooperativas. (Assmann, 2005; p. 18).

Os professores tem que está consciente do valor nas novas tecnologias e seu auxilio no Ensino. As TE tem uma gama de recursos que favorecem o aprendizado em sala de aula. Ela é uma extensão de potencialidade dentro do ensino atualmente. Os professore, para facilitar e potencializar suas atividades, tem que buscar conhecer as funcionalidades que oferece as TE e, assim usá-las com seus alunos, facilitando a atividade pedagógica.

Para Assmann (2012) o conceito de informação admite muitos significados. O passo da informação ao conhecimento é um processo relacional humano, e não mera operação tecnológica.

Como explicita Assmann, as tecnologias são muito mais que a mera operacionalidade tecnológica. Ela admite vario e amplos significados. Desde que estes sejam explorados pelos professores e aplicados corretamente em sala de aula.

Segundo Lima e Silva (2012) as últimas décadas têm testemunhado uma gradual evolução das tecnologias da informação. A evolução tecnológica tem sido veloz e surpreendente passando a sociedade atual a ser chamada de "sociedade da informação". Diante desta sociedade, fica praticamente impossível manter as novas tecnologias distantes do ambiente escolar, já que estas poderão oferecer a toda à escola um espaço muito mais enriquecedor, com variados instrumentos de informação, possibilitando aos alunos uma aprendizagem significativa.

As TIC entrou na vida da sociedade impactando com seus desenvolvimento e recursos ultramodernos. O avanço tecnológico parece incombatível. Ele esta sempre em constante desenvolvimento e aperfeiçoamento. O professor não pode parar de se capacitar para oferecer melhores recursos de aprendizagem para seus alunos e, estabelecer atividades dinâmicas que levem os alunos a interagir com as tecnologias que iram potencializar o aprendizado. 


\section{ENSINO DA MATEMÁTICA MEDIADO PELAS TIC}

Alegre (2005) afirma que a rede mundial (Internet) é uma nova forma de comunicação e integração entre pessoas, altamente dinâmica. A Internet propicia a criação, organização e a integração com a informação e estas estão influenciando a relação ensinoaprendizagem. O computador deve dar as condições dos alunos exercitarem a capacidade de procurar e selecionar informação, resolver problemas e aprender a aprender.

Segundo Camponez (2015) a educação em geral enfrenta muitas dificuldades, em particular a Educação da Matemática, em que tem apresentado em índices estatísticos, grandes fracassos. Esse insucesso se deve a vários fatores. É grave a maneira eficiente de como se forma o professor, essas lacunas são observadas nos currículos dos cursos de licenciatura, nos conteúdos das disciplinas, na definição dos pressupostos pedagógicos.

Seguindo Camponez (2015) o uso dos recursos tecnológicos nas aulas de matemática pode promover alterações na estrutura da sala de aula e também na maneira de ensinar e de aprender os conteúdos. Portanto os professores precisam conhecer as possibilidades e também os limites das tecnologias, estando preparados para utiliza-los como apoio ao processo de ensino e aprendizagem.

Percebe-se que as TIC provocam mudanças nas pessoas e sistemas. Com o uso das mesmas, o educador terá de refletir sobre as várias formas de construção do conhecimento. Por isto, deverá repensar a metodologia e o processo ensino-aprendizagem num ambiente interativo e dinâmico.

A Matemática está presente na Engenharia, na Física, na Astronomia, na Psicologia, na Biologia, na Informática, etc., e em, praticamente, qualquer área do conhecimento humano e científico. A evolução das TIC permite aplicar métodos da Matemática para resolver problemas do mundo real, de forma inovadora e rápida, tem grande influência neste fato. 
O uso das novas tecnologias propicia trabalhar em sala de aula com investigação e experimentação na Matemática, considerando que permite ao aprendiz vivenciar experiências, interferir, fomentar e construir o próprio conhecimento. $\mathrm{O}$ aluno participa dinamicamente da ação educativa através da interação com os métodos e meios para organizar a própria experiência. A participação do professor como facilitador do processo ensino-aprendizagem é relevante para permitir que o aluno desenvolva habilidades e seja capaz de realizar a atribuição de significados importantes para sua articulação dentro do processo ensino-aprendizagem. Nesse contexto, cabe citar a contribuição de Mason, quando nos alerta para o fato de "[...] que para usar um instrumento matemático com eficácia, pode ser necessário gastar algum tempo a examinar o que está por trás dele, como funciona, e mesmo como isso poderia ser feito, em princípio, à mão" (Mason, 2005; p. 19).

D’Ambrósio constata que:

Estamos entrando na era do que se costuma chamar a "sociedade do conhecimento". A escola não se justifica pela apresentação de conhecimento obsoleto e ultrapassado e muitas vezes morto, sobretudo, ao se falar em ciências e tecnologia. Será essencial para a escola estimular a aquisição, a organização, a geração e a difusão do conhecimento vivo, integrado nos valores e expectativas da sociedade. Isso será impossível de se atingir sem a ampla utilização de tecnologia na educação. Informática e comunicações dominarão a tecnologia educativa do futuro. (D’Ambrósio, 1996; p. 80).

O uso da tecnologia em sala de aula permite interatividade entre o aprendiz e o objeto de estudo propiciando uma participação ativa do aluno e uma reflexão acerca dos recursos tecnológicos computacionais, criando condições de aprofundamento sobre a fonte das ferramentas que criam a oportunidade para criar um ambiente de aprendizagem e implementar o design instrucional apropriado. Segundo a literatura acadêmica brasileira, o termo design instrucional traduz-se de forma bastante ampla como "planejamento de ensino".

O professor deve buscar meios de "transformar" o conteúdo matemático através de formas metodológicas que são pedagogicamente eficientes e adaptáveis à realidade dos alunos, isto é, o conhecimento pedagógico do conteúdo, deve fazer sentido para o professor 
que ensina, proporcionando assim sentido para o aluno que aprende (Demo, 2004). Na verdade, não é adquirida somente com observações, e sim, através de uma busca constante de recursos e ações que possibilitem essa prática. Aqui o professor de matemática não pode deixar de usar analogias, demonstrações, experimentações, exemplos, contraexemplos, representações, inclusive a sequência que dá aos conteúdos e a ordenação de um assunto em diferentes tópicos, como ferramentas pedagógicas.

Segundo Assmann (2012) é preciso distanciar-se tanto dos escolhos do tecnootimismo ingênuo (tecnointegrados) como do rechaço medroso da técnica (tecnoapocalípticos). Em muitos ambientes escolares, persiste o receio preconceituoso de que a mídia despersonaliza, anestesia as consciências e é uma ameaça à subjetividade.

4.1. Recursos Tecnológicos usados no auxilio do aprendizado de matemática

Os recursos tecnológicos são ferramentas que podem auxiliar o desempenho das atividades pedagógicas. Ajudando assim os alunos ao aprendizado com maior potencialidade, facilidade e motivação. A realizarem as atividades programáticas com maior desempenho e potencialidade. Os recursos tecnológicos são inúmeros. A cada dia que se passa são criados recursos tecnológicos de maneira exorbitante.

A análise das redes sociais é um elemento adicional na compreensão dos modelos de aprendizagem na era digital. Kleiner (2002) explora a "quantum theory of trust" de Karen Stephenson que "explica não apenas como reconhecer a capacidade cognitiva coletiva de uma organização, mas como cultivá-la e aumentá-la”. Dentro de uma rede social, hubs (pontos comuns de conexão de dispositivos) são pessoas bem conectadas que são capazes de estimular e manter o fluxo do conhecimento.

Vários são os recursos tecnológicos, a calculadora, um retro projetor, o vídeo e até a mais simples de todas as ferramentas tecnológicas: o giz. Todos esses recursos já é há algum tempo, parceiros do profissional da educação, porém, quando falamos do uso de microcomputadores e seus softwares educativos, estamos nos referindo a uma potencial 
ferramenta que ainda não se encontra, de forma aceitável, inserida na prática docente do professor de matemática.

Romero (2006) em sua fala traz sua concepção acerca do ensino com e sem o uso de softwares em sala de aula,

A tecnologia, especificamente os softwares educacionais disponibiliza oportunidade de motivação e apropriação do conteúdo estudado em sala de aula, uma vez que em muitas escolas de rede pública e particular, professores utilizam recursos didáticos como lousa e giz para ministrarem suas aulas, este é um dos diversos problemas que causam o crescimento da qualidade não satisfatória de ensino, principalmente na rede estadual. (Romero, 2006; p. 1).

Brown (2002) apresenta uma noção interessante de que a internet alavanca os pequenos esforços de muitos com os grandes esforços de poucos. A premissa central é que conexões criadas com nós não usuais suportam e intensificam atividades de grande esforço existentes. Brown fornece o exemplo do projeto de sistema do Maricopa County Community College que junta cidadãos seniores com alunos das escolas básicas em um programa de tutores. As crianças "escutam melhor esses "avós" do que seus próprios pais, o programa de tutores realmente ajuda os professores, os pequenos esforços da maioria os seniores - complementam os grandes esforços dos poucos - os professores." (2002). Essa amplificação da aprendizagem, conhecimento e compreensão através da extensão de uma rede pessoal é a síntese do conectivismo.

Aqui apresentamos alguns recursos tecnológicos específicos usados no aprendizado da matemática:

a) Jogo, Matemática para Criança:

Este jogo contem adição, subtração, multiplicação e divisão. É um jogo dinâmico que oferece ao aluno um aprendizado diferenciado do tradicional. Tipo de jogo: de classificação livre. Versão 2.0; atualizado em 20 de novembro de 2016; downloads mais de 1.000.000 downloads; tamanho do downloads 3,17 MB; oferecido por Minikler Ogreniyor; 


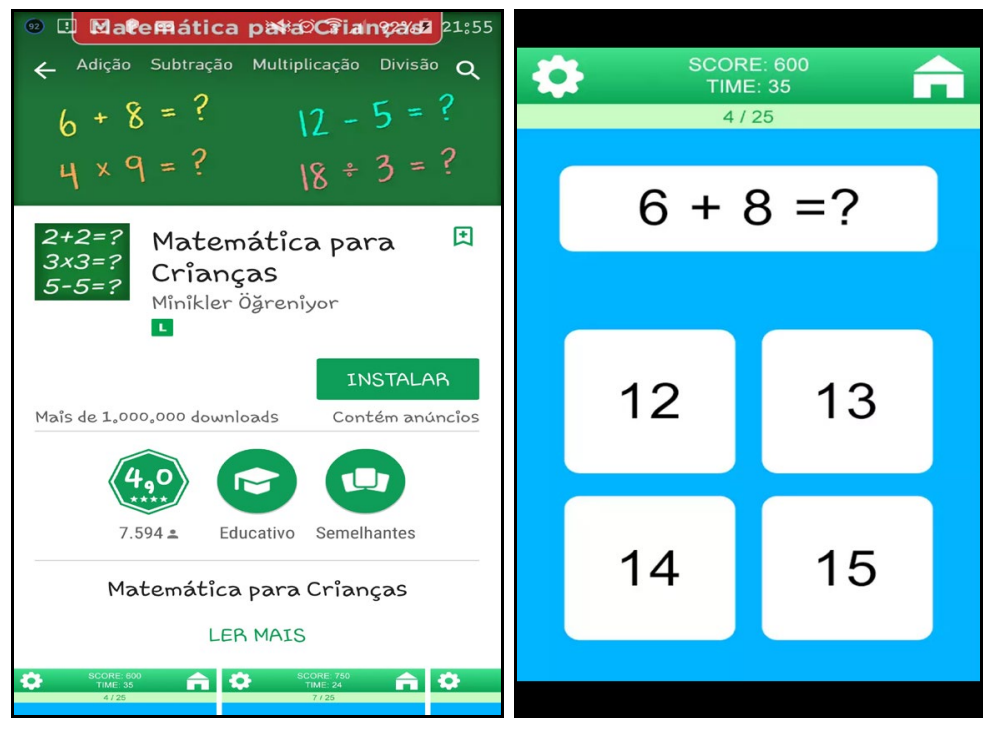

Figura 02: Jogo: Matemática para criança

Fonte: elaboração própria com base no Play Store.

b) Jogo: Desafio Matemático Grátis:

Jogar e aprender a melhorar a capacidades cognitivas do aluno. O jogo foi aprovado e incluído pela Google play para a educação.

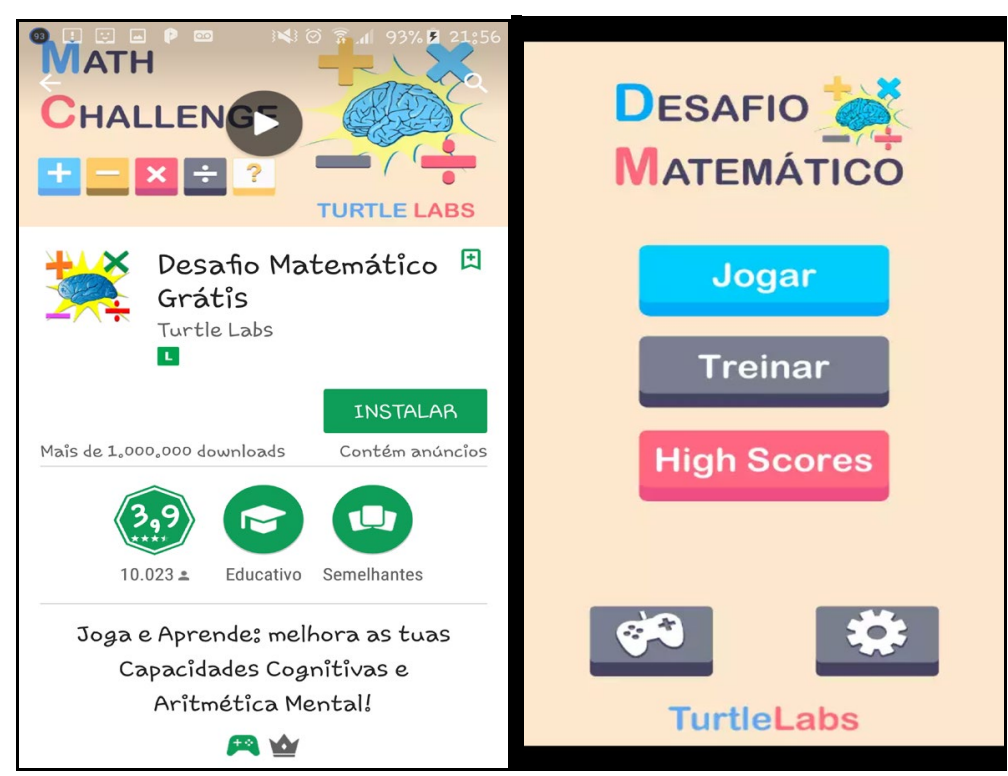

Figura 03: Jogo: Desafio Matemático Grátis.

Fonte: elaboração própria baseada no Play Store. 
O jogo apresenta varias modalidades como: a) duelo; jogar contra amigos. b) Quadrados Saltitantes: onde bons instintos e coordenação encontram uma mente rápida. Função: torna a mente um instrumento ainda mais poderoso usando a aplicação Desafio Matemático e aumenta a capacidade cognitiva do aluno e aritmética mental.

O segredo para uma mente saudável e jovem está no continuado uso dos poderes mentais em desafios cognitivos tais como aqueles oferecidos pelos jogos que podem encontrar nesta aplicação. Mas quão diferente pode ser um jogo educativo. Acredita-se na Turtlelabs, que pode ser significativamente diferente e melhor.

Oferece aqui uma estética diferente e foi criado um novo e diferente modo de jogar. O app Desafios Matemáticos vai decerto melhorar a capacidades matemáticas. Tem a opção modo de treino onde o aluno pode praticar a sua vontade e aprender sem qualquer pressa ou então poderá escolher um dos muitos modos de jogo e aceitar o desafio proposto.

Torna a mente do aluno um instrumento muito mais poderoso usando a aplicação Desafio Matemático e aumenta as suas capacidades cognitivas e aritmética mental. O segredo para uma mente saudável e jovem está no continuado uso dos poderes mentais em desafios cognitivos tais como aqueles oferecidos pelos jogos que pode encontrar nesta aplicação.

O App Desafio Matemático vai de certo melhorar as capacidades matemáticas do aluno. Tem a opção modo de treino onde pode praticar a vontade de aprender sem qualquer pressa ou então poderá escolher um dos muitos modos de jogo e aceitar o desafio que propõe cada um.

c) Jogo: Perguntas de Matemática:

É um jogo que testar a habilidade velocidade na luta contra o tempo. Diversas perguntas para os alunos se divertirem, aprender e ativar a mente muito mais. Pode começar o jogo no nível fácil, após algumas perguntas o jogo começa ficar mais difícil. Pode usar ajudar para passar de nível. Versão 1.9; atualizado em 3 de dezembro de 2016; downloads mais de 10.000 downloads; tamanho do download 8,55 MB; oferecido por DJ Mobile. 


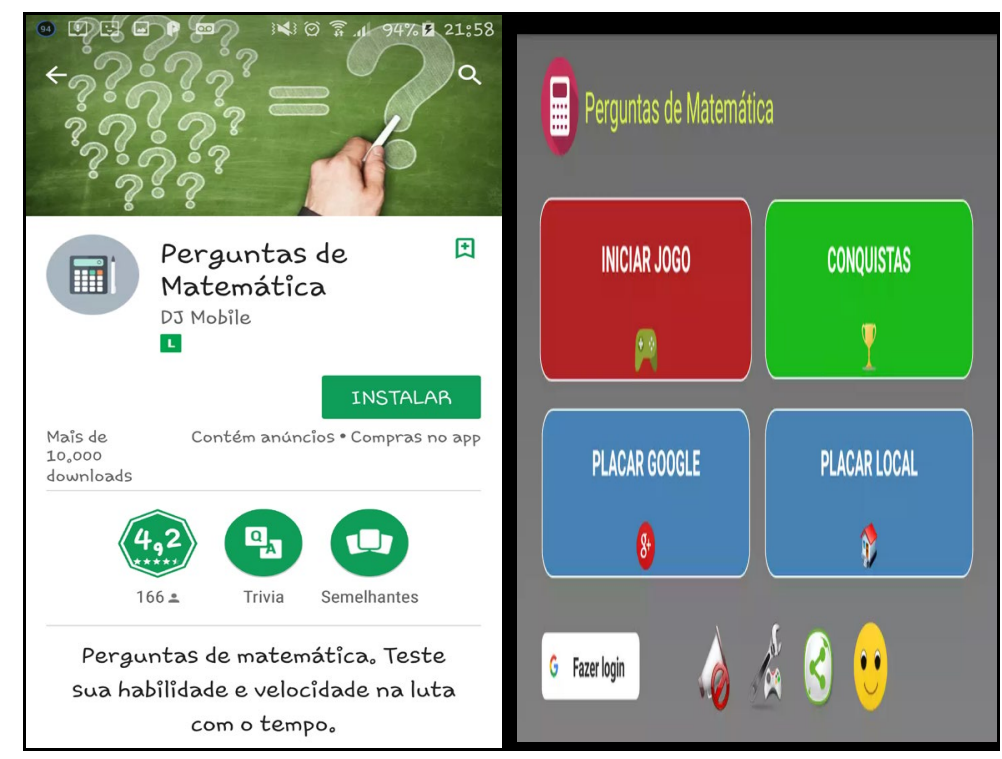

Figura 04: Jogo, Perguntas de Matemática.

Fonte: elaboração própria baseada no Play Store.

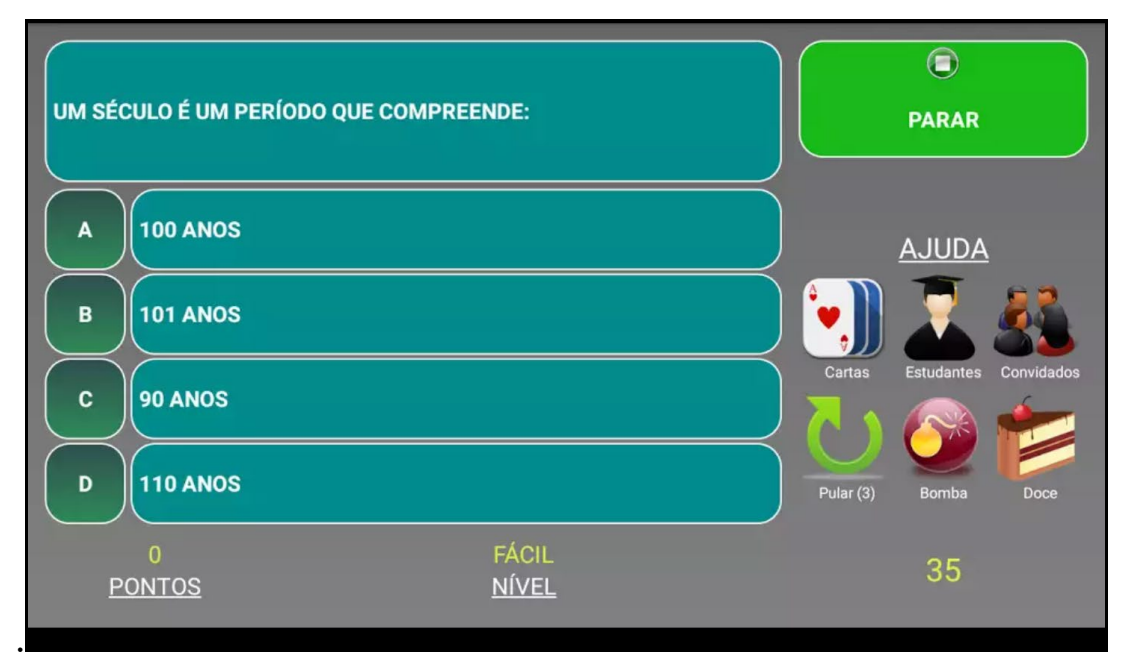

Foto 05: Jogo, Perguntas de Matemática.

Fonte: elaboração própria baseada no Play Store.

d) Jogo: Caça Palavras - Matemática:

Versão 1.0,4; atualizado em 26 de janeiro de 2017; downloads mais de 100.000 downloads; tamanho do downloads 2,76 MB; oferecido por Big Brain Kraken. 


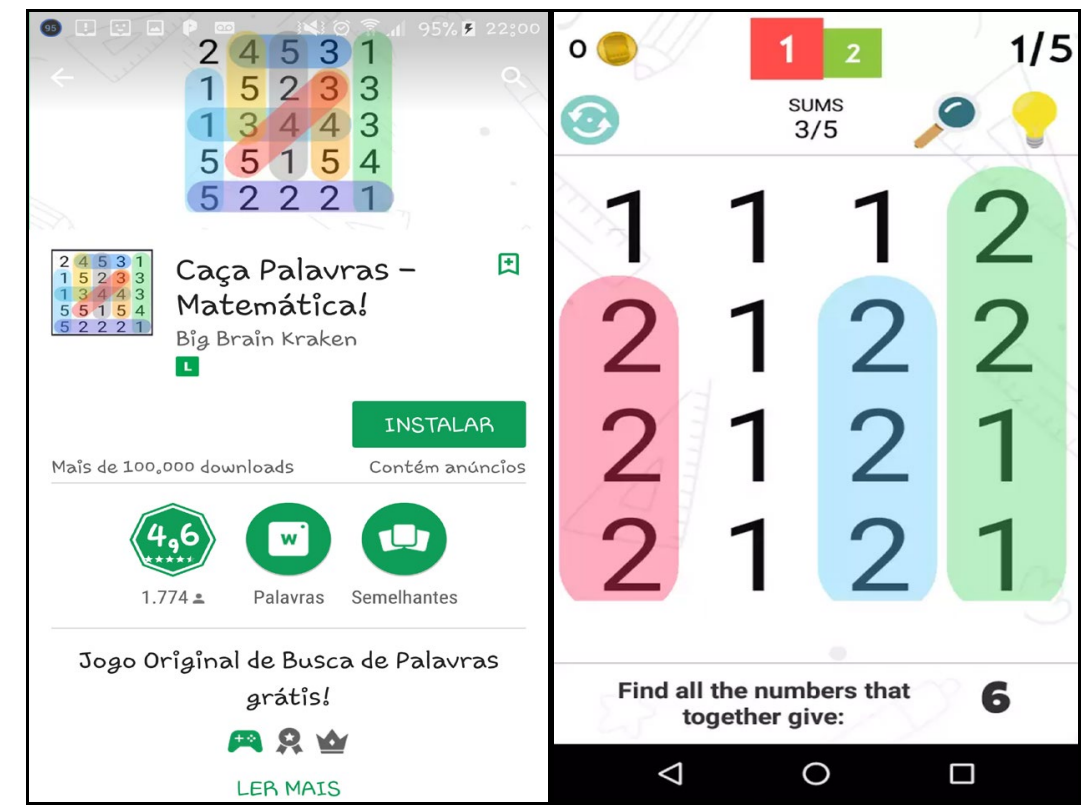

Figura 06: Jogo, Matemática para Crianças.

Fonte: elaboração própria baseada no Play Store.

Nesse jogo de caça palavras o aluno tem que buscar os números que juntos dão o número alvo. $\mathrm{O}$ aluno irá jogar de jogos fáceis 4 x 4 até o desafio maiores à medida de avançar.

O jogo oferece: Tabuleiro de liderança (Social ou Todos) disponível para que o aluno possa desafiar os seus colegas; Sistema de ajuda original para melhorar a jogabilidade enquanto o aluno procurar uma soma, o jogo irá ajudá-lo a encontrar o resto deles. Disponível para celular, tablet 7 polegadas ou dispositivos HD de 10 polegadas e a dispositivos pequenos ou de baixa resolução.

e) Jogo Mestres da Matemática:

Mestre da Matemática é um jogo em que o aluno tem que resolver um monte de exercícios de matemática interessantes, passar um teste de matemática, testar o seu cérebro para se conhecer e saber como pode contar mentalmente, e desenvolver esta habilidade, se necessário. 


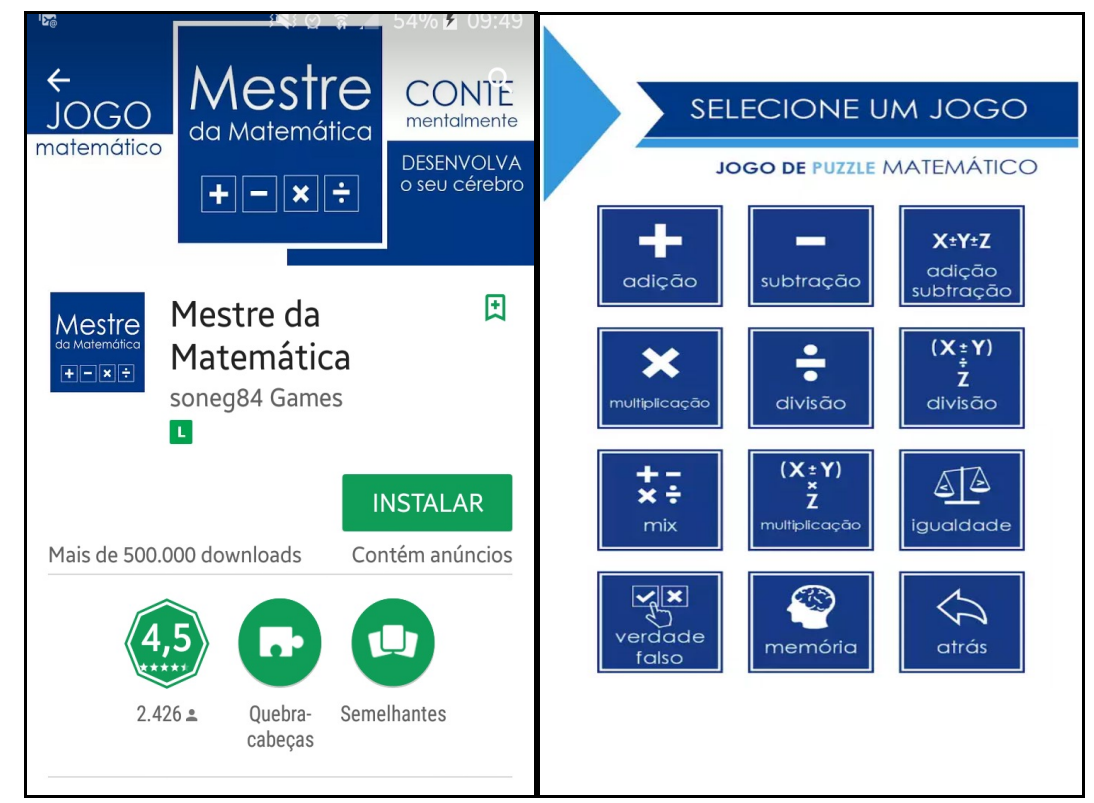

Figura 07: Jogo Mestre da Matemática.

Fonte: elaboração própria.

O jogo disponibiliza de recursos que pode ajudar o aluno a aprender a contar de forma rápida e sem erros, desenvolver o pensamento abstrato e lógico, fortalecer a inteligência, desenvolver a perseverança, aumentar o nível de QI, capacidade de analisar a sua memoria.

Este jogo é apropriado para jovens e adultos. Com vários níveis a partir do mais simples aos extremamente complexos, todos vão encontrar algo adequado. Com cada nível as tarefas tornam-se ainda mais difíceis e interessantes. Treinar o cérebro e melhorar as habilidades de matemática (é um excelente treinador de matemática).

As tecnologias, em suas diferentes formas e usos, constituem um dos principais agentes de transformação da sociedade, pelas modificações que exercem no cotidiano das pessoas. (BRASIL, 2001; p. 46).

f) Cola Matemática: Disponível para iOS (gratuito) e para Android (gratuito);

Apesar de ter "cola" no nome, ele não deve ser usado assim. É o aplicativo mais útil se você quiser verificar o passo a passo de um exercício, para aprendê-lo e não errar de novo. Ele te dá as opções de escolher o tipo de operação ou figura que quer ver 
solucionada, colocar os números, e voilà: ver em detalhes como resolver a questão.
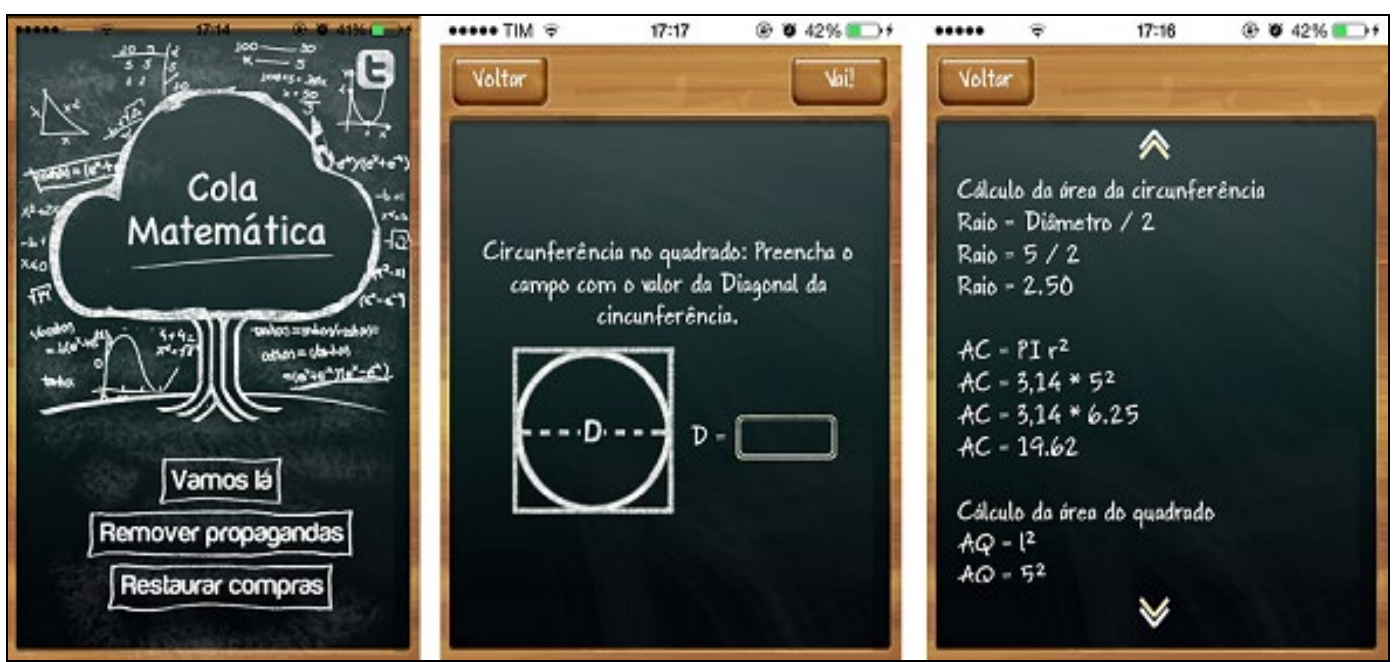

Figura 08: Aplicativo Cola Matemática.

Fonte: https:/guiadoestudante.abril.com.br/estudo/6-aplicativos-para-estudar-matematica.

g) MathYou: Disponível para iOS (gratuito);

Esse aplicativo é, literalmente, um gerador de contas. O MathYou gera tanto operações simples (como adição, multiplicação, potenciação), quanto expressões e equações complexas, com frações, potências e raízes. Ele é perfeito se você quer treinar sua habilidade em resolver contas.

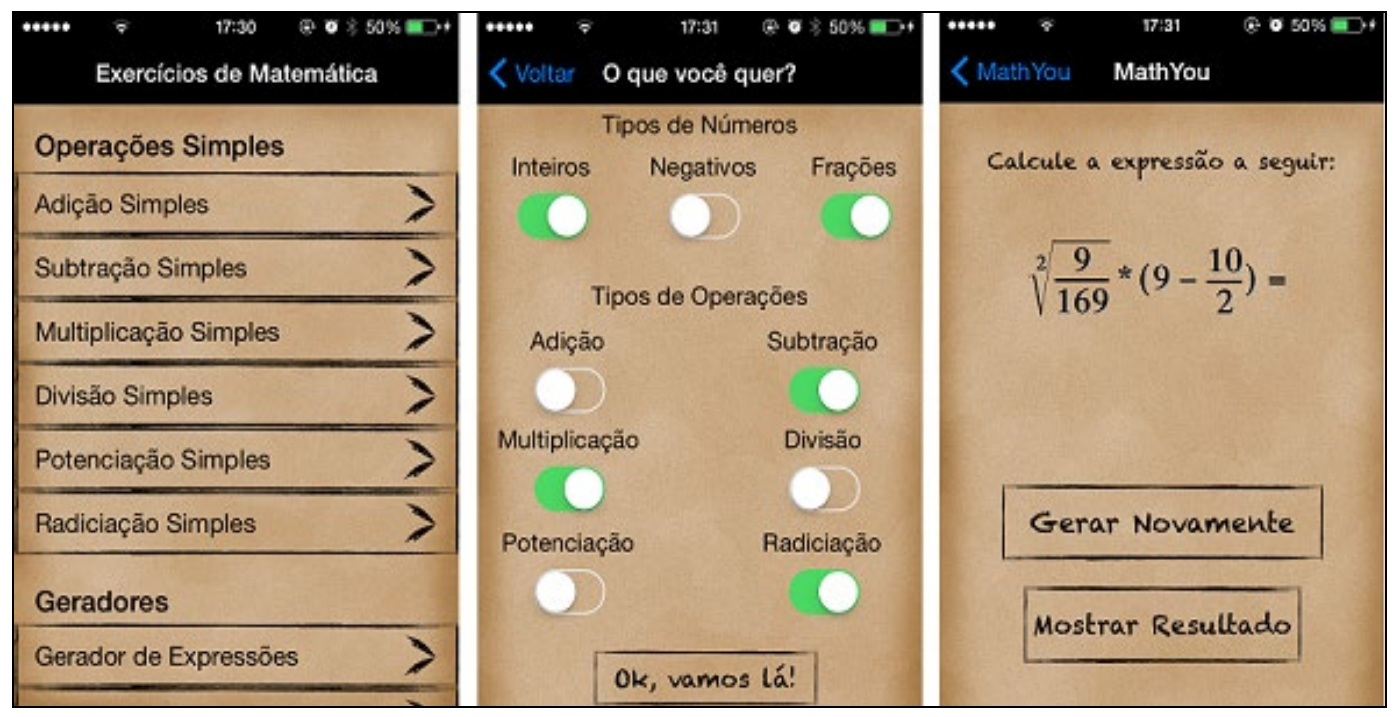

Figura 09: Aplicativo MathYou.

Fonte: https:/guiadoestudante.abril.com.br/estudo/6-aplicativos-para-estudar-matematica. 
h) Rei da Matemática: Disponível para iOS (versão gratuita e paga) e para Android (só versão paga)

O Rei da Matemática funciona como um jogo: você é morador de um reino e começa como agricultor. Para avançar, você deve ir solucionando os problemas de Matemática, e à medida que sua pontuação cresce, você muda de posição. A versão gratuita só tem as opções adição, subtração e combinado 1, que mistura as duas. Já a versão paga conta com geometria, frações, potências, entre outros.
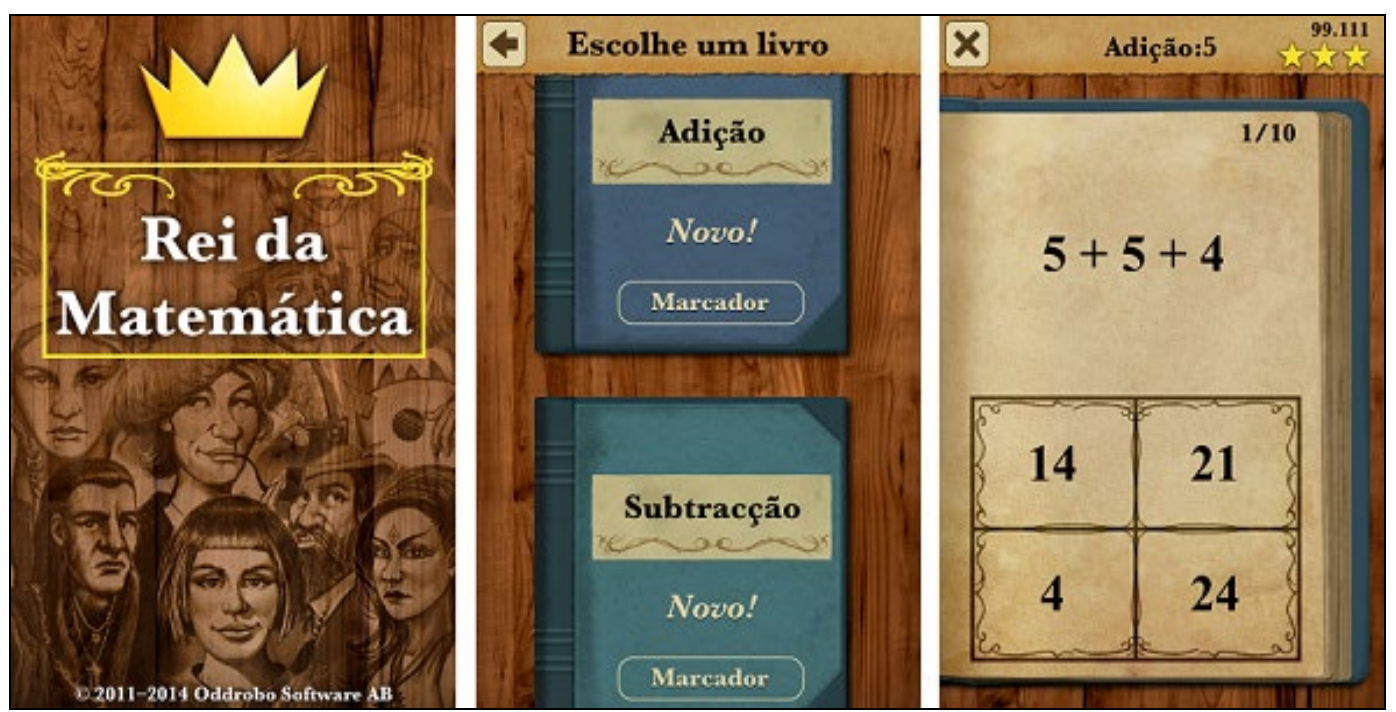

Figura 10: Aplicativo Rei da Matemática.

Fonte: https://guiadoestudante.abril.com.br/estudo/6-aplicativos-para-estudar-matematica.

Mas até que ponto as TIC podem contribuir para o desenvolvimento do saber matemático? E porque pesquisas nessa área encontra inúmeros impasses na sua aplicabilidade pelos professores de matemática? Há vários anos são realizadas pesquisas sobre o ensino de matemática e os resultados trazem sempre à problemática do déficit entre o que se espera que o aluno esteja apto a desenvolver e que nível realmente ele se encontra.

Acredita-se que uma das razões pode estar relacionada aos processos de ensino dos professores, pois se verifica que suas práticas geralmente não fazem o vínculo entre os conteúdos e as situações reais dos alunos, trabalhando de forma mecânica, avaliando através da memorização que servem apenas para a prova e provavelmente serão esquecidas 
posteriormente.

Tal realidade torna o processo de ensino-aprendizagem descontextualizado e sem significação. Vale salientar que a matemática hoje é parâmetro de conhecimento, de posição social, de nível cultural, é de grande importância no desenvolvimento da tecnologia, dos indivíduos ou de uma região, pois é uma construção humana.

Um dos maiores educadores matemáticos fala que:

É preciso substituir os processos de ensino que priorizam a exposição, que levam a um receber passivo do conteúdo, através de processos que não estimulem os alunos à participação. É preciso que eles deixem de ver a Matemática como um produto acabado, cuja transmissão de conteúdos é vista como um conjunto estático de conhecimentos e técnicas. (D’Ambrósio, 2003; p. 45). 


\section{A INFLUÊNCIA DAS TIC NO DESENVOLVIMENTO DO APRENDIZADO DOS ALUNOS}

Para Guillemas (2006) as novas tecnologias se associa sistematicamente uma espécie de reação de euforia social não controlada que não se sabe muito bem si tem sua origem na própria tecnologia ou na capacidade de surpresa que dela se deriva. Agora bem, se nossa compreensão da técnica e nossa capacidade de admiração não nos permitem ir más da admiração imediata, então a mesma técnica nos impede dar-nos conta de que com elas abrimos caminhos, mas ninguém tem de se sentir obrigado a transita-los.

Está claro que las innovaciones tecnológicas no producen innovación per se puesto que ni el individuo ni la comunidad es capaz de darles contenido funcional hasta que ha conseguido crearse la necesidad de su uso, y aunque dicha necesidad puede ser muy evidente en algunos sectores profesionales, no siempre lo es en el ámbito de la educación de lenguas, en donde la mayor parte de las veces se las usa como sucedáneo moderno de aquello que se ha venido haciendo tradicionalmente sin ellas: periódicos en español, libros en español, música en español, recetas de cocina en español o letras de canciones. (Guillemas, 2006; p.3).

Temos que considerar que temos que afrentar, que devemos render-nos à evidencia de que as novas tecnologias não vieram de passagem, e sim vieram para ficar, e como existem que ser sábio pois já que não podemos lutar contra elas, o melhor é que nos adaptemos a sua presença e as incorporemos a nossa vida cotidiana, o que significa que devemos abordar seu uso desde a análises crítica e sendo consciente de que podemos fazer com ela e quais serão as consequências que de seu uso se derivam.

Atualmente todo o contexto está envolvido pelas tecnologias. $\mathrm{Na}$ vida social, educativa e laboral as pessoas não vivem mas sem o uso continuo das tecnologias. $\mathrm{O}$ mundo globalizado está praticamente girando $100 \%$ entorno das tecnologias. É impossível, 
hoje, o professor entrar na sala de aula e não saber lidar com as tecnologias, hoje se faz necessário que todos os sujeitos da educação tenham noção das TIC, nem que seja as mais básicas no momento e, a tendência global é que todos façam uso continuo das TIC para impulsionar o ensino-aprendizado.

Segundo Amaral et all (2014) o professor de Ciências e Matemática do século XXI deve abandonar a ideia de transmissor do conhecimento para aprender a aprender a ensinar, isto é, propiciar a criação de ambientes de aprendizagem. Além disso, tem de ser mais do que um professor, precisa assumir o papel de educador (agente principal de formação do cidadão).

O professor para alcançar seus objetivos necessita de uma ferramenta de complementação e aperfeiçoamento na sala de aula que são as TIC (agregar valor ao processo ensino-aprendizagem). O bom ou mau uso das TIC depende dos conhecimentos, habilidades e atitudes do educador sobre elas. Castells (2000) em seu livro apresenta as características importantes das TIC que são: a informação é a matéria-prima, a flexibilidade das TIC no ensino-aprendizagem, o uso das TIC através da rede mundial (Internet), a informação é parte integrante da vida humana e a convergência das TIC para um sistema altamente integrado.

Como explicita Guillemas (2006) as novas tecnologias não necessitam de novos alunos ou novos professores, necessitam ser consideradas como o que são, ferramentas auxiliares e potenciadoras de uma nova conceitualização do ensino. Quando entendamos em que consiste a nova conceitualização do ensino, e somente então, seremos capazes de rentabilizar a inversão pessoal e institucional em tecnologia.

Baseado em Guillemas (2006) na base desta grande revolução educativa se encontram alguns conceitos práticos e novos dos que depende o correto desenvolvimento de metodologias e procedimentos:

- Capacidade de conexão à rede tanto desde o ponto de vista da infraestrutura como do conhecimento.

- Necessidades de aprendizagem e prestigio do conhecimento como, mas valia 
do individuo na sociedade.

- Desenvolvimento de conteúdos de qualidade.

- Aceitação do papel das novas tecnologias como ferramentas de aprendizagem.

Quando os sujeitos da educação têm conhecimentos dos conceitos práticos que depende o correto desenvolvimento de metodologias direcionadas ao melhor desempenho das atividades pedagogias as quais favoreceram o aprendizado com qualidade aos alunos, o processo acontece com maior fluência e qualidade. O professor passar a trabalhar com mais segurança e o aluno aprende com mais facilidade e significação.

O aprendizado significativo se dar quando o aluno na realização das atividades práticas estabelecidas pelo professor, se dar com maior eficácia e fazendo com que o aluno não só aprenda o conteúdo como também saiba dialogar com propriedade.

Para Silva (2013) perante de tanta tecnologia e informações tecnológicas é necessário se pensar em uma educação que trabalhe com os conhecimentos de forma contextualizada, ou seja, com conhecimentos que contribuam com a formação de cidadãos capazes de dar respostas às necessidades de uma sociedade em constante transformação.

Segundo Silva (2013) nesse sentido, busca-se responder: a inserção da tecnologia na educação contribui para o processo EA, pois promove e facilita a interação entre o conhecimento e a construção da autonomia, portanto o uso da tecnologia na educação é uma ferramenta significativa, uma vez que diversifica a prática pedagógica do professor em sala de aula, estimulando consequentemente o interesse e a participação do aluno, melhorando a aprendizagem.

O aprendizado é um dos fatores primordiais dentro da educação. Para que o aprendizado significativo aconteça é preciso que o professor esteja munido de um leque de conhecimentos que potencialize sua pratica pedagógica facilitando assim seu trabalho em sala de aula. As TIC tem oferecido aos professores, a educação, ao ensino, ao aprendizado um leque de recursos que potencializam o desempenho do aprendizado e motive os alunos a buscarem mais conhecimentos em conjunto ou individualmente. 
Quando se fala em saber matemático, fala-se de movimento, temos que pensar em algo além da sala de aula, algo que venha de fora, passe pela escola de forma significativa e que produza conhecimento de verdade para ser utilizado por todos.

Sabemos que, como toda tendência de ensino as TIC não são a solução final dos problemas de ensino aprendizagem, longe disso, todas essas tendências possuem pontos fortes e limitações, o que se espera nesse texto é refletir a partir de uma experiência em sala de aula as características dessa linha de pesquisa e contribuir para futuras análises.

\subsection{Alunos nativos digitais}

De acordo com Prensky (2001) a IE é tida como ponto de partida das mudanças, mas, atualmente, está defasada e precisa passar por um processo de renovação; principalmente, para os alunos que estão chegando, os nativos digitais.

Ressalta Xexéo (2003) que os nativos digitais são os alunos que nasceram na Internet, a partir de $1^{\circ}$ de Janeiro de 1983, quando ela surgiu como é atualmente, isto é, a rede mundial começa a adotar o protocolo TCP/IP como língua de comunicação entre dois computadores para trocas de informações.

Eles são pessoas que usam a linguagem digital dos computadores, vídeo games e a Internet. Além disso, há os estudantes Imigrantes Digitais que são aqueles antes da Internet utilizam computadores e as redes, mas ainda imprimem o que irão ler. Os alunos nativos digitais são adolescentes que ao mesmo tempo ouvem música, assistem TV, trocam mensagens instantâneas, falam ao celular e realizam pesquisas na Internet. Para poderem realizar estas funções, o sistema nervoso dos nativos digitais libera neurotransmissores e provoca alterações nos neurônios. São formadas novas conexões neurais. Estes novos estudantes, nativos digitais, estão chegando ao ensino médio e terão grandes dificuldades de aprendizagem e falta de motivação, se forem mantidos os métodos de ensino atuais.

Segundo Nevado (1999) os professores precisam familiarizar-se rapidamente com 
o uso das TIC para que estes alunos nativos digitais não achem suas aulas sonolentas e desestimuladoras. Os professores que somente usam livros didáticos para planejar e desenvolver suas aulas, a qualidade de ensino fica comprometida.

\subsection{As TIC favorecendo a interação entre o aprendiz e o aprendizado}

É interessante ressaltar o valor das TIC quando se tratar da interação entre o aprendiz e o aprendizado. As TIC tem recursos estimuladores que potencializam a interação entre não somente os alunos e o aprendizado como também entre professores alunos e conteúdos a serem estudados ou trabalhados em sala de aula.

Para Morales (2011), toda a vida na classe é relação de um tipo ou de outro: o professor explica, pergunta, responde, informa; comunica-se verbalmente de muitas maneiras, enquanto que os alunos escutam, perguntam, respondem e também se comunicam não verbalmente de muitas maneiras; dizem algo enquanto aguardam e também estão dizendo quando estão distraídos.

Segundo Piaget (1951) ressalta que assim como o meio físico não se impõe de uma vez nem num só bloco, à inteligência em evolução do EA, se não que podem seguir passo a passo as aquisições em funções da experiência de igual modo o meio social dar lugar a interações, entre o individuo em desenvolvimento e seu entorno.

Quadro 01: Enfoque Construtivista do Processo de Aprendizagem.

\begin{tabular}{|l|l|}
\hline \multicolumn{1}{|c|}{ ENFOQUES } & \multicolumn{1}{|c|}{ CARACTERÍSTICAS } \\
\hline METAS & Construção de saberes com sentido e significados. \\
\hline DESENVOLVIMENTO & $\begin{array}{l}\text { Edifica-se o conhecimento sobre as experiências, saberes prévios e sobre o } \\
\text { mundo. }\end{array}$ \\
\hline DOCENTE & Estudante relação (horizontal). \\
\hline CONTEÚDOS & $\begin{array}{l}\text { Temáticas variadas dependem do interesse e conhecimento do } \\
\text { participante. }\end{array}$ \\
\hline
\end{tabular}


MÉTODO DIALÉTICO $\quad$ Interação entre as pessoas e com o entorno interpretativo reflexivo.

Fonte: www.google.com.br/imagens (acessado em 20, maio.2018).

São vários os valores das TIC dentro do contexto EA. Aqui abordaremos alguns dos quais aproximam os alunos dos professores e consequentemente os professores dos alunos. As TIC pode aumentar a interatividade entre o professor do aluno, ajudar no processo de EA como agente motivador. Esta é uma realidade que deve ser considerada dentro do processo EA. Mas o professor não detém todo o saber nem precisa enfrentar essas mudanças sozinhas, e uma boa opção para debater o uso da tecnologia em sala de aula é a participação em grupos de discussão, com profissionais que possuem objetivos comuns e, juntos, suscitam questões importantes sobre o tema.

Para Oliveira e Villardi (2005) no plano da educação, esta possível transferência de afetos e de conteúdos inconscientes não substitui ou esvazia de sentido, mas completa a relação com o adulto educador e interfere na evolução da identidade do aluno. Quando falamos de educação isso não implica necessariamente em repasso de conteúdos e conhecimentos direcionado somente para um fim, no intervim desse processo EA aparecem outros valores que somam com a atividade pedagógica que embora não sejam visíveis ou notáveis elas estão em toda parte, e se manifestam futuramente na vida do aluno.

Não podemos deixar de considerar que o lado efetivo dos alunos, por sua vez, é sensibilizado pela maneira em que o professor se relaciona em classe com eles. A interação pode ser mais ampla por meios das atividades práticas, e dos recursos que o professor leva para realizar suas atividades. Os alunos de hoje são muito criteriosos, exigentes dentro do processo EA. Podendo até mesmo a questionar a competência do docente em aula. Eles percebem quando o professor não está preparado ou não os valorizam como alunos que estão ali para aprender, e que isto pode ser entendido quando o professor entra em sala de aula qualificado com recursos propícios ao desenvolvimento das aulas em questão. As TE e seus recursos têm favorecido aos professores muitos recursos que propiciam esta relação professor-aluno, e que por sua vez, aumenta a interesse dos alunos, os motivam ao desenvolvimento de seus estudos. 
Sob o olhar da abordagem histórico- cultural construída por Vygotsky (1989), o professor em sua relação com o aluno deve conduzir à apreensão dos significados tomados como também dos conceitos elaborados, além de fazer uso de instrumentos e da própria linguagem em seu processo da EA, tornando o conhecimento mais acessível.

Para Vygotsky (1989) a construção do psiquismo humano está totalmente vinculada à relação (interação) homem-realidade e à forma como o primeiro se apropria/constrói signos e significados. É importante abordar este aspecto.

Para Oliveira e Villardi (2005) é possível que as TIC, com destaque para o computador, assim como a Educação propiciam, de forma progressiva, todas as formas de interação (desde a síncrona, quando o grupo interage ao mesmo tempo e no mesmo lugar, e a forma semipresencial, que permite a interação in loco, até a modalidade assíncrona distribuída em que a interação ocorre em diferentes tempos e lugares - como nos chats), permitindo sempre o encontro educacional pleno.

A interação, segundo Belloni (2001) ocorre com a intersubjetividade. Esta mesmo mediatizada por um vínculo técnico comunicacional significa encontro entre sujeitos, estando envolvidos aspectos socioafetivos. É muito importante o professor usar estratégias nas suas aulas onde os alunos possam ser envolvidos como um todo durante e depois da aplicação das atividades buscando assim favorecer a interação entre eles e os conteúdos abordados em suas aulas. A interação entre os alunos aumenta o grau de interesse por parte dos alunos a buscarem e trocarem conhecimentos.

Para Lima e Silva (2012) esses novos instrumentos tecnológicos fornecem várias informações ao mesmo tempo, fazendo com que ocorra uma aprendizagem mais interativa, criativa e uma construção coletiva do conhecimento. As tecnologias inseridas nas aulas poderão estar colaborando com uma melhor e mais ampla apreensão dos conteúdos justamente porque as mesmas já fazem parte da sociedade em que o aluno está inserido, já fazem parte do seu dia-a-dia.

A interação mediada segundo Oliveira e Villardi (2005) promove incrivelmente a linguagem socializada e as competências sócias de cooperação e reciprocidade, por meio dos grupos de discussão que são geralmente apreciados pelos adolescentes. 
Para Bombonatto et at. ( 2008), a conversação terapeuta como uma busca recíproca de compreensão e à exploração, por meio do diálogo, dos problemas que, conforme vão sendo apresentados, possibilitam a busca de novas narrativas que façam sentido para o sistema e que se encaixam naquelas circunstâncias, naquele momento, para aquelas pessoas.

Está visão é de suma importância para o processo EA de matemática, pois o próprio método aplicado, hoje, ao ensino de matemática atribuir o valor do raciocínio para o desenvolvimento do aprendizado de matemática especifico em questão, ela estimula os alunos efetivamente a buscas de novos conhecimentos, e leva-os expressassem melhor e desenvolver a competência lógica das atividades estudadas.

Para Oliveira e Villardi ( 2005) a interação quando enuncia quase todos os seus conceitos favorece o desenvolvimento do aprendizado. A importância da comunicação, principalmente a propiciada pelo ambiente interativo da Educação via online:

Sem descartar nenhum dos materiais e meios, pois todos eles têm importantes funções a cumprir, realçando-se a importância de dispor de tecnologias que permitam uma comunicação sincrônica e o estabelecimento de um diálogo educativo entre os distintos atores do processo ensinoaprendizagem (Ahijado e Martin. 1999; p. 44).

Por sua vez a interatividade envolve dois sentidos: a potencialidade apresentada por um determinado meio e a atividade do usuário (aluno), atuando sobre a máquina e sofrendo, por parte desta, uma "retroação". A interatividade verdadeira para Oliveira \& Villardi (2005) ocorre, no entanto, na aprendizagem (como é passível de acontecer dentro da educação e em softwares em que a ação do usuário -aluno- determina o andamento da estrutura dos aplicativos).

Notou-se a importância da interatividade desse novo ambiente virtual. A interatividade segundo Silva e Santos (2004) significa a libertação do constrangimento diante da lógica da transmissão que predominou no século XX. Portanto, a interatividade deve ser encarada como meio de comunicação que desafia a mídia de massa buscando a participação de forma a ajustar o uso das tecnologias, diante do paradigma da transmissão, 
fazendo da sala de aula interativa, o local onde o educador e o educando podem intermediar através da participação e colaboração de modo síncrono e assíncrono.

Para Demo (2009) ao estar conectado à internet, o usuário pode ser ator e autor do processo de aprendizagem através da troca de ações, controlando os acontecimentos e fazendo as alterações do conteúdo.

Assim, a interatividade permite que ao aluno torna-se sujeito ativo diante do processo ensino aprendizagem. É necessário ter consciência desse fato, diante do esgotamento do modelo educacional atual baseado no falar do professor e na pouca oralidade do aluno. Indo mais além, é necessário caminhar além da percepção de que o conhecimento não esta mais centrada na emissão.

Segundo Lima e Silva (2012) dentro deste contexto, ganha importância a questão da postura do professor, do seu posicionamento frente à tecnologia em uso na educação. Para tanto, o educador precisa se preparar e questionar sobre a sua própria práxis e sobre o seu papel perante esta nova sociedade da informação. O educador precisa ter em mente que não pode mais ficar indiferente a esta situação, ou seja, indiferente a implantação desses meios tecnológicos em suas aulas.

O professor deve estar aberto às inovações tecnológicas, precisa saber manusear os novos instrumentos tecnológicos, recursos, aplicativos que as TE disponibiliza, utilizando-os em prol do processo ensino-aprendizagem e buscando a interatividade dos alunos na produção do conhecimento.

\subsection{O valor da interação professor/alunos no EA de Matemática}

Para Oliveira e Villardi (2005) a interiorização, a reversibilidade e a combinação, aspectos construtivistas das operações mentais, da mesma maneira que a operação de conservação pode ser também aprimorada. Acrescenta mais que a interação mediada promove incrivelmente a linguagem matemática socializada e as competências sociais de cooperação e reciprocidade, por meio dos grupos de discussão - geralmente apreciados 
pelos adolescentes. Estes aspectos são muito importantes dentro do processo EA de Matemática.

Quadro 02: Ações do professor e necessidades dos alunos.

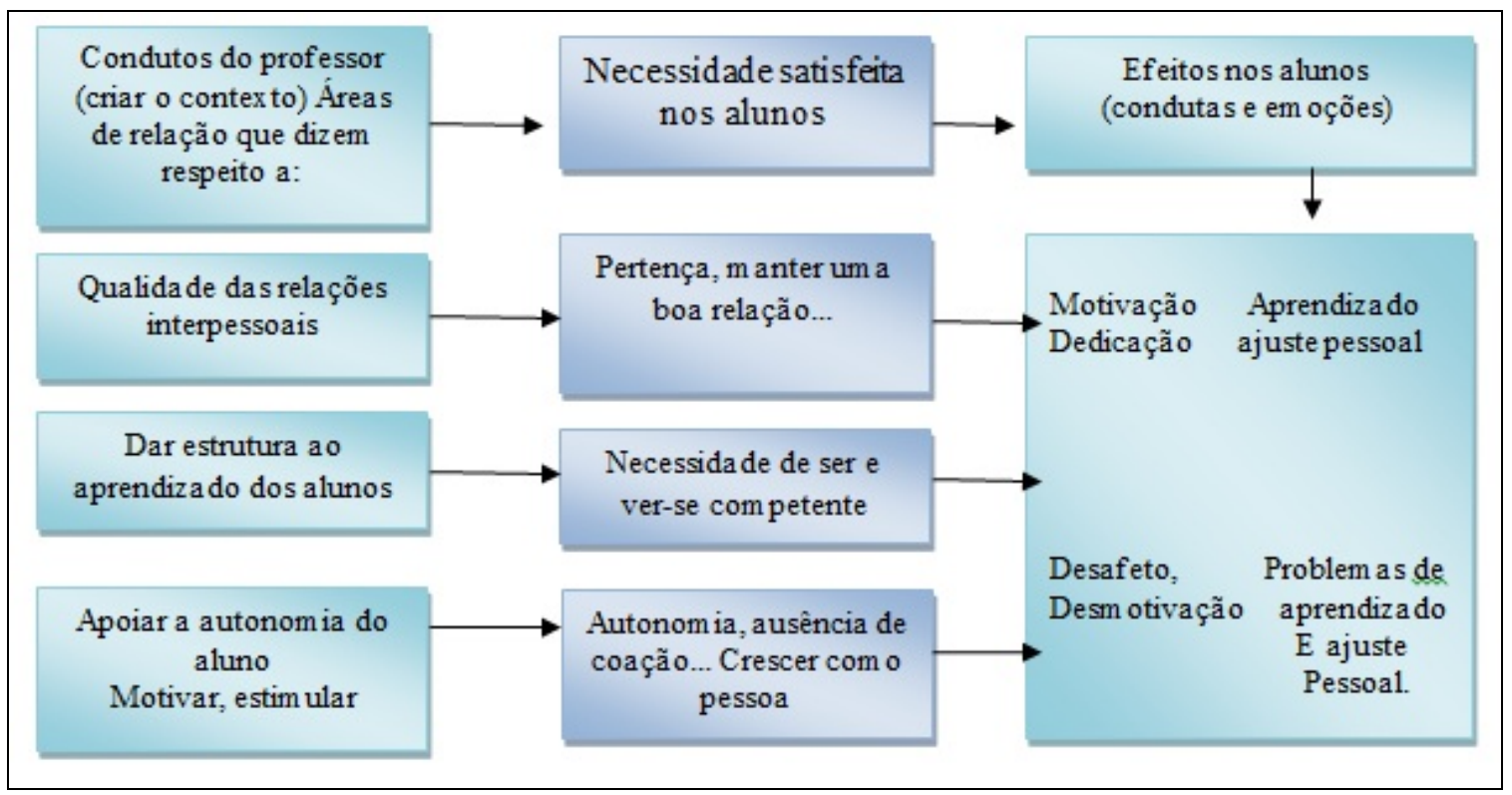

Fonte: Morales (2011).

A interação das relações interpessoais manifesta-se de muitas maneiras: dedicar tempo à comunicação com os alunos, a manifestar afeto e interesse, ou seja, demonstrar que eles importam para nós, a elogiar com sinceridade, a interagir com os alunos com prazer. O oposto a isso é a rejeição, a distancia, a simples ignorância a respeito dos alunos, o desinteresse dos mesmos ao EA.

Uma conclusão que aparece em muitas pesquisas sobre o que acontece na sala de aula é que: com frequência, os alunos menos motivados, menos comprometidos com seu aprendizado, menos ativos recebem de seus professores comentários, ou tipo de comunicação, que os desmotivam ainda mais. E, ao contrário, os alunos que desde o início se mostram ativos e motivados recebem mais reforços do professor, mais comunicação (Morales, 2011; p.87).

A interação mediada pelo docente é de suma importância dentro do processo EA. Os alunos sentem a necessidade dessa interação mediada pelos professore que estimular ao 
aprendizado. Os alunos tem um comportamento muito restrito perante a sociedade, praticamente podemos consideramos como alunos passivos, ou seja, que pouco interagem com os professores com o receio de errar ou de se manifestar na presença dos companheiros de classe, e se o professor não tiver está a iniciativa de fazer com eles interagem entre aluno/aluno e aluno/professor, o processo EA pode fracassar nos seus objetivos de aprender com eficiência dentro do tempo planejado. Eles demonstram, na maioria das vezes, a necessidade da intervenção do docente durante as aulas.

Os professores respondem mais, atendem mais aos alunos que desde o início mostram maior interesse, perguntam mais, mostram-se ativos. Ao contrario, a passividade do aluno faz com que o professor se considere incompetente ou não se sinta do agrado dos alunos e, consequentemente, lhe dedique menos tempo, aplique mais pressões externas (mais coerção) e coloque menos ilusão em sua tarefa.

Segundo Piaget (2013), que bem enfatiza a necessidade de que se considere o homem como um todo, incluindo afetividade e emoção:

As construções (...) cognitivas, necessárias à elaboração das operações, são inseparáveis de construção (...) afetivas e sociais. O termo "social” não deve ser entendido como no sentido único, demasiadamente estreito embora já muito amplo, das transmissões educativas, culturais ou morais: tratam-se mais ainda de um processo interindividual de socialização, cognitivo, afetivo e moral ao mesmo tempo. (p. 78).

Segundo Oliveira e Villardi (2005), diz que a capacidade para as aprendizagens colaborativas e grupais e a intensa relação com as tecnologias de informação e comunicação, no entanto, começam bem antes, em um momento que muitos chamam de pré-adolescência ou idade escolar, ou ainda média meninice, em que muitos dos processos cognitivos citados são prenunciados. É muito importante a participação do aluno para construir o conhecimento e a própria comunicação. Para tal, o uso dos elementos da Web 2.0 aliado à sala de aula tradicional vislumbra uma modelo de sala de aula interativa.

Para Bombonatto, Do Valle e Maluf (2008), a aprendizagem social acontece de diversas formas e, também, pela comunicação tecnológica, e é a base formadora de cultura, em sua opinião. Dentro do EA de LE, um dos fatores mais valorizados nela é o valor 
cultural da língua estudada, especificamente procuramos, hoje, ensinar a matemática valorizando a interação de aprendizagem entre os alunos, valorizando o raciocínio lógico entre os sujeitos estimulando valores que favoreça um aprendizado mais rico.

É importante ressaltar que a interação com o computador facilita, através da ativação de funções da zona de desenvolvimento proximal, o alcance de níveis mais elevados de desenvolvimento relacionado com o EA. Para Oliveira e Villardi (2005), o computador nunca substitui o adulto/educador ou o grupo, mas multiplica as situações em que a citada zona é ativada. Para Alarcão (2011) temos que reconhecer que o exercício livre e responsável da cidadania exige das pessoas a capacidade de pensar e a sabedoria para decidir com base numa informação e em conhecimento sólidos.

Segundo Oliveira e Villardi (2005) a utilização de tantos recursos não significa, no entanto, abandonar o convívio, a socialização e a aprendizagem em grupo, tão valorizados. Como relata Oliveira, a relação entre as TIC e os alunos ampliam a interação, a comunicação e o aprendizado dos alunos, tanto individualmente como em grupos, é um complemento dentro da EA.

Seguindo com Belloni (2001), as TIC trata de uma "cultura digitalizada", na qual as crianças e os jovens de hoje estão imersos desde os primórdios da vida. A autora destaca, como características dessa cultura, a fragmentação e a extensão horizontal do conhecimento, além da possibilidade de transitar alimente de um assunto para outro.

O ponto em comum das atuais elaborações construtivistas está dado pela afirmação de que o conhecimento não é o resultado de uma mera copia da realidade preexistente, se não de um processo dinâmico e interativo por meio do que a informação externa é interpretada e reinterpretada pela mente que vai construindo progressivamente modelos explicativos cada vez mais complexos e potentes.

Então, notou-se a importância da interatividade desse novo ambiente virtual. A interatividade segundo Silva (2004) significa a libertação do constrangimento diante da lógica da transmissão que predominou no século XX. Portanto, a interatividade deve ser encarada como meio de comunicação que desafia a mídia de massa buscando a participação de forma a ajustar o uso das tecnologias, diante do paradigma da transmissão, 
fazendo da sala de aula interativa, o local onde o educador e o educando podem intermediar através da participação e colaboração de modo síncrono e assíncrono.

Nessa perspectiva de inovação no processo de ensino aprendizagem foi que se apontou que a formação de educadores para fazer uso das TIC no processo educacional torna-se relevante e imprescindível preparando-o constantemente para enfrentar os desafios das mudanças educacionais. Em meio a este processo, os educadores necessitam compreender, que a Web 2.0, como um dos recursos das TIC ,está sendo uma mídia que potencializa a abertura de novos caminhos para o ensino aprendizagem.

A integração potencial do texto, imagens e sons num mesmo sistemainteragindo a partir de pontos múltiplos, no tempo escolhido (real ou atrasado) em uma rede global em condições de acesso aberto e de preço acessível - muda de forma fundamental o caráter da comunicação. [...] O surgimento de um novo sistema eletrônico de comunicação caracterizado pelo seu alcance global, integração de comunicação e interatividade potencial esta mudando e mudará para sempre nossa cultura. (Bergman, 2007; p. 698).

Ao estar conectado à internet, o usuário pode ser ator e autor (Demo, 2009) do processo de aprendizagem através da troca de ações, controlando os acontecimentos e fazendo as alterações do conteúdo. Assim, a interatividade permite que ao aluno torna-se sujeito ativo diante do processo ensino aprendizagem.

É necessário ter consciência desse fato, diante do esgotamento do modelo educacional atual baseado no falar do professor e na pouca oralidade do aluno. Indo mais além, é necessário caminhar além da percepção de que o conhecimento não esta mais centrada na emissão. A utilização do computador, conectado à internet, foi um dos mais importantes elementos dessas novas tecnologias.

Para Oliveira e Villardi (2005) incluir efetivamente no ethos tecnológicos da nossa cultura, embora os números da exclusão digital ainda sejam preocupantes, o computador passou a fazer parte do cotidiano da criança a habilidade em sua utilização é valorizada pelo grupo e pela sociedade. 
A interação que estabelece a aplicação dos recursos tecnológicos com os alunos durante no auxilio das atividades propostas em aula é maior que quando se propõe outras atividades ditas como tradicionais, onde estão envolvidos elementos como livro "escrito" e caderno. O contato com as redes sociais é muito influente hoje na vida de nosso alunado, por isso o professor, aqui, deve mudar sua visão quando se fala em prática pedagogia, e também buscar repensar a maneira de planejar suas aulas, buscando sempre levar o aluno além do horizonte que as vezes, o livro didático limita, o aprendizado por meios das TIC é mais amplo e ilimitado. Um tema pode levar tanto o professor como o aluno a adquirir outras competências e conhecimentos.

Segundo Quintas (1993) que o aprender a relacionar-se estimula a estabelecer novos tipos de relações humanas, pode trabalhar em equipe, aprender a escutar, desenvolver sua capacidade de comunicação, aprende a liderar, aprender a servir, aprende a postergar-se. Aprendendo a relaciona-se aprende a formar graus mais importantes de unidades entre os alunos.

Dentro do contexto do aprendizado colaborativo, passam a aprender a socializar os conhecimentos adquiridos e a aprender mais com os seus companheiros de classe. A troca de informação durante a aula não depende somente do professor para o aluno, mas também do aluno para o aluno, dentro da visão do construtivismo, o aprendizado dever ser colaborativo e construído a partir de pré-adquiridos e adquiridos socialmente.

5.4. O uso pedagógico das mídias na escola como práticas inovadoras

Ao longo dos anos a mudança em torno da tecnologia tem conseguido uma profundidade veloz. Tendo em vista que a tecnologia tem mostrado grande importância no desenvolvimento da sociedade, é necessário que a escola também se insira nessa revolução tecnológica, pois os alunos já fazem parte de uma geração totalmente integrada ao mundo das mídias, daí a mudança na prática do professor para que possa ofertar ao aluno uma educação apropriada para o uso consciente e reflexivo das tecnologias. 
O trabalho com a tecnologia exige do professor uma nova forma de educar, pois a revolução da tecnologia acontece independentemente de estar ou não em um planejamento da escola, pois os alunos que já convivem com essa tecnologia inovadora em seu cotidiano já sentem a necessidade de que escola desenvolva seu trabalho partindo dela.

Assmann (2005), afirma que:

"As novas tecnologias da informação e da comunicação já não são meros instrumentos no sentido técnico tradicional, mas feixes de propriedades ativas. É algo tecnologicamente novo e diferente. As tecnologias tradicionais serviam como instrumentos para aumentar o alcance dos sentidos (braço, visão, movimento, etc.). As novas tecnologias ampliam o potencial cognitivo do ser humano (seu cérebro/mente) e possibilitam mixagens cognitivas complexas e cooperativas.” (Assmann, 2005; p.18).

Com isso, é necessário que seja ampliado a visão que o professor tem sobre o uso das novas tecnologias em sala de aula. Não basta para eles apenas utilizar mecanicamente as ferramentas tecnológicas, mas também, saber para que deve usar, como usar e que impacto terá na aprendizagem do aluno.

Hoje quando um aluno tem dúvida ele não pergunta mais ao professor, pergunta ao Google a inteligência virtual, isso demonstra que estamos vivendo em uma nova era e a escola precisa fazer parte, oferecendo a essa nova geração inclusão digital através de atividades que a leve a ser produtor e divulgador do conhecimento. Para que essa inclusão seja efetivada é preciso romper com estruturas arcaicas que impossibilitam o professor a vislumbrar as possibilidades de inovação da sua prática, superando o receio das tecnologias digitais.

A tecnologia se apresenta com o objetivo de inovar a prática docente, atribuir significado a essa prática e garantir a expansão da aula real em um momento virtual, unificando o presencial e o ensino a distância, deixando as tarefas de casa mais criativas e agradáveis de serem feitas.

A pedagogia de projetos é uma oportunidade que a escola encontra para introduzir tecnologia na sala de aula. Esses projetos precisam de tempos maiores que os projetos 
escolares, precisam ser mais dinâmicos, criativos e que leve o aluno a perfazer o trajeto da autoria, para não se tornar um mero repetidor de conhecimentos já elaborados. Os projetos precisam conduzir os alunos para coisas que eles precisam saber, proporcionando um ambiente virtualmente interativo para que ele possa sentir-se estimulado a participar e criar. Os projetos atuais apenas se preocupam em transmitir conteúdos disciplinares, transferir conhecimentos, mas isso não basta para o aluno que está nas salas de aula.

Segundo Chaves (1998) é preciso também ajudar as pessoas a:

i) Aprender a pensar, a argumentar, e a se exprimir com clareza, precisão e objetividade, na língua materna e em pelo menos duas línguas estrangeiras (que, no caso do Brasil, são Inglês e Espanhol);

ii) Compreender que há uma diferença essencial entre absorção passiva de fatos e assimilação criativa de informação;

iii) Aprender, no tocante a informações a discernir os tipos de informação relevantes para suas necessidades e seus interesses; a descobrir onde essas informações estão armazenadas e como obtê-las; a avaliar e criticar as informações encontradas e recebidas; a analisar as informações que se mostrem confiáveis e a relacioná-las com outras informações que já possuem· a organizar suas informações, arquivá-las inteligentemente e, quando necessário, recuperá-las com rapidez e apresentá-las de maneira concisa e atraente;

iv) Descobrir como, com base nas informações de que dispõem, construir projetos de vida, definir objetivos, metas e prioridades, e encontrar as melhores formas de alcançar esses objetivos e metas;

v) Entender que o conhecimento pode e deve se traduzir em ação e assimilar o processo de tomada de decisão;

vi) Encontrar formas de lidar eficaz e eficientemente com mudanças rápidas e com situações novas;

vii) Aprender a relacionar-se com as pessoas, negociar, administrar conflitos e lidar com pressões; 
viii) Aprender a gerenciar o tempo;

ix) Entender que a aprendizagem, e, por conseguinte, a educação, é um processo constante, que se estende pela vida toda, no qual o papel da escola é relativamente pequeno, e que, portanto, a principal responsabilidade pela educação é sempre da própria pessoa. (Chaves, 1998; p.58-59).

A ênfase terá que ser no desenvolvimento dessas habilidades e competências, o computador e as TIC são meios, ferramentas. E os educadores não devem jamais perder de vista a finalidade desta escola sem se deixar encantar pelos meios, a tecnologia é mais um recurso disponível (agrega valor à aprendizagem) que deve ser utilizado para favorecer o processo de ensino-aprendizagem.

Para Amaral et all (2014) é nessa direção que é possível visualizar os contornos que eventualmente levarão à invenção de uma nova escola, a escola da Sociedade da Informação para a geração net (2.0). Esta escola ajudará as pessoas a dominarem as habilidades e competências exigidas pela Sociedade da Informação e preparará seus alunos para viverem e atuarem, como pessoas, como cidadãos e como profissionais.

É também importante que o professor-orientador pense na forma de avaliação dos alunos, pois conforme Perrenoud et al. (2002) afirma, a avaliação das competências atua como formativa: a avaliação das competências deve ser formativa, passar por uma coanalise do trabalho dos estudantes e pela regulação de seus investimentos, mais do que pelas notas ou pelas classificações e ao professor, resta trabalhar a partir das concepções dos alunos, dialogar com eles, fazer com que sejam avaliadas para aproximá-las dos conhecimentos científicos a serem ensinados. A competência do professor é, então, essencialmente didática.

É importante que os professores atuais devem deixar de lado seus receios e medos e precisam procurar à aventura do espírito o senso de criatividade e inovação. A Instituição de Ensino (IE) tem obrigação de participar dando condições reais e inovadoras de trabalho ao educador e propiciando programas de capacitação docente continuada. Isto reflete o que Freire (1998) fala sobre abertura ao risco, pois há uma grande defasagem educacional. As TIC podem e devem ser usadas na educação, e de diversas maneiras, mas isso não as torna educacional ou educativa. As Instituições de Ensino terão a função de criar os AVAs junto 
com os professores, onde os discentes possam ser orientados para buscar as informações, avaliá-las, analisá-las, organizá-las, não perdendo de vista os seus objetivos.

Para Amaral (2014) o fracasso escolar, a repetência e a falta de interesse pela escola são resultados desta forma de ensinar. O computador e as outras TIC podem tornar o ambiente globalizado, interativo e facilitador da criatividade e inovação. $\mathrm{O}$ aluno nativo digital é o criador do próprio conhecimento. O educador será o facilitador da aprendizagem do nativo digital com o uso das TIC (agregar valor ao processo ensino-aprendizagem).

As TIC estarão na vida acadêmica e depois, paulatinamente, passarão para a sala de aula, mas há necessidade de que este processo seja muito mais rápido do que atualmente ocorre. Se isto não acontecer, a escola terá graves problemas com os nativos digitais. 


\section{MARCO METODOLÓGICO}

Esta pesquisa surgiu a partir da necessidade de demonstrar que as TIC também tem favorecido com os recursos tecnológicos que ela oferece para o aprendizado de matemática. A pesquisa propõe a analisar as Contribuições das TIC à aprendizagem de matemática dos alunos das escolas municipais de Campina Grande, Paraíba, Brasil. A pesquisa foi realizada com alunos e professores das escolas: Escolas Municipais Lafayete Cavalcante e Manoel da Costa Cirne, situadas no município de Campina Grande, Paraíba, Brasil.

$\mathrm{Na}$ realidade da educação nordestina temos uma carência de professores doutores pesquisadores na área das Tecnologias Educativas e, quando se faz referencia ao ensinoaprendizado de matemática a carência é maior.

\subsection{O Problema da pesquisa}

As Escolas Municipais Lafayete Cavalcante e Manoel da Costa Cirne, situadas no município de Campina Grande, Paraíba, contam com 625 alunos e 38 professores em 18 salas de aula distribuídos nos turnos matutino, vespertino e noturno. As instituições contam com sala de informática com computadores com acesso a internet. Durante a pesquisa realizada por Silva (2015) foi constatado que o uso do laboratório de informática contribui para o desenvolvimento de habilidades e competências matemáticas dos alunos.

Diante de este contexto surge a pergunta do problema da pesquisa: houve melhoria no desempenho dos alunos das Escolas Municipais Lafayete Cavalcante e Manoel da Costa Cirne que estudam matemática utilizando as TIC? 
6.2. As perguntas da pesquisa

As perguntas da pesquisa são:

1) Como estimar a diferença no rendimento acadêmico dos alunos que têm acesso às TIC aos que não têm acesso?

2) Como se verificar se índices de aprovação e reprovação pode ser influenciado pelo uso das TIC nas escolas?

3) Como estabelecer se os alunos se sentiram mais estimulados a estudar matemática utilizando as TIC?

\subsection{Os Objetivos da Pesquisa}

O Objetivo Geral da pesquisa é: Analisar a forma que o uso das TIC influencia no aprendizado da disciplina matemática dos alunos das Escolas Municipais Lafayete Cavalcante e Manoel da Costa Cirne.

Os objetivos especificos da pesquisa são:

1) Verificar a diferença no rendimento acadêmico dos alunos que têm acesso às TIC aos que não têm acesso;

2) Identificar- se índices de aprovação e reprovação pode ser influenciado pelo uso das TIC nas escolas;

3) Identificar se os alunos se sentiram mais estimulados a estudar matemática utilizando as TIC. 


\subsection{Local da Investigação}

\subsubsection{Histórico da Cidade de Campina Grande, Paraíba, Brasil}

É um município brasileiro no estado da Paraíba. Considerada um dos principais polos industriais da Região Nordeste bem como um dos maiores polos tecnológicos da América Latina, foi fundada em 1 de Dezembro de 1697, tendo sido elevada à categoria de cidade em 11 de outubro de 1864. Pertence à Microrregião de Campina Grande e à Mesorregião do Agreste Paraibano. De acordo com estimativas de 2017, sua população é de 410.332 habitantes, sendo a segunda cidade mais populosa da Paraíba, e sua região metropolitana, formada por dezenove municípios, possui uma população estimada em 638 017 habitantes.

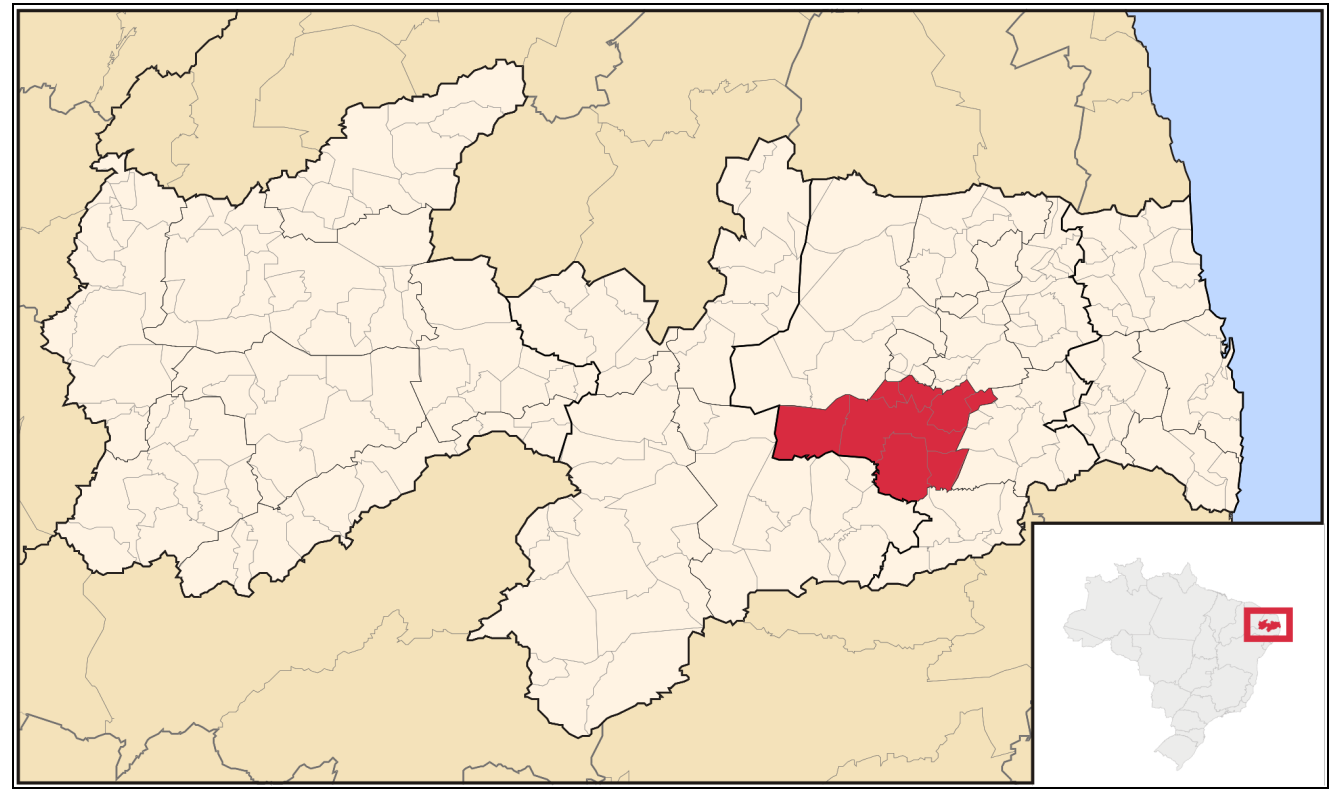

Figura 11: Localização da cidade de Campina Grande no mapa da Paraíba, Brasil. Fonte: https://commons.wikimedia.org/wiki/File:Paraiba_Micro_CampinaGrande.svg.

Campina Grande é um importante centro universitário, contando com dezessete universidades e faculdades, sendo três delas públicas. É também uma das cidades com proporcionalmente o maior número de doutores do Brasil, 1 para cada 590 habitantes, seis vezes a média nacional. Além de ensino superior, o município é destaque também em centros de capacitação para o nível médio e técnico. 


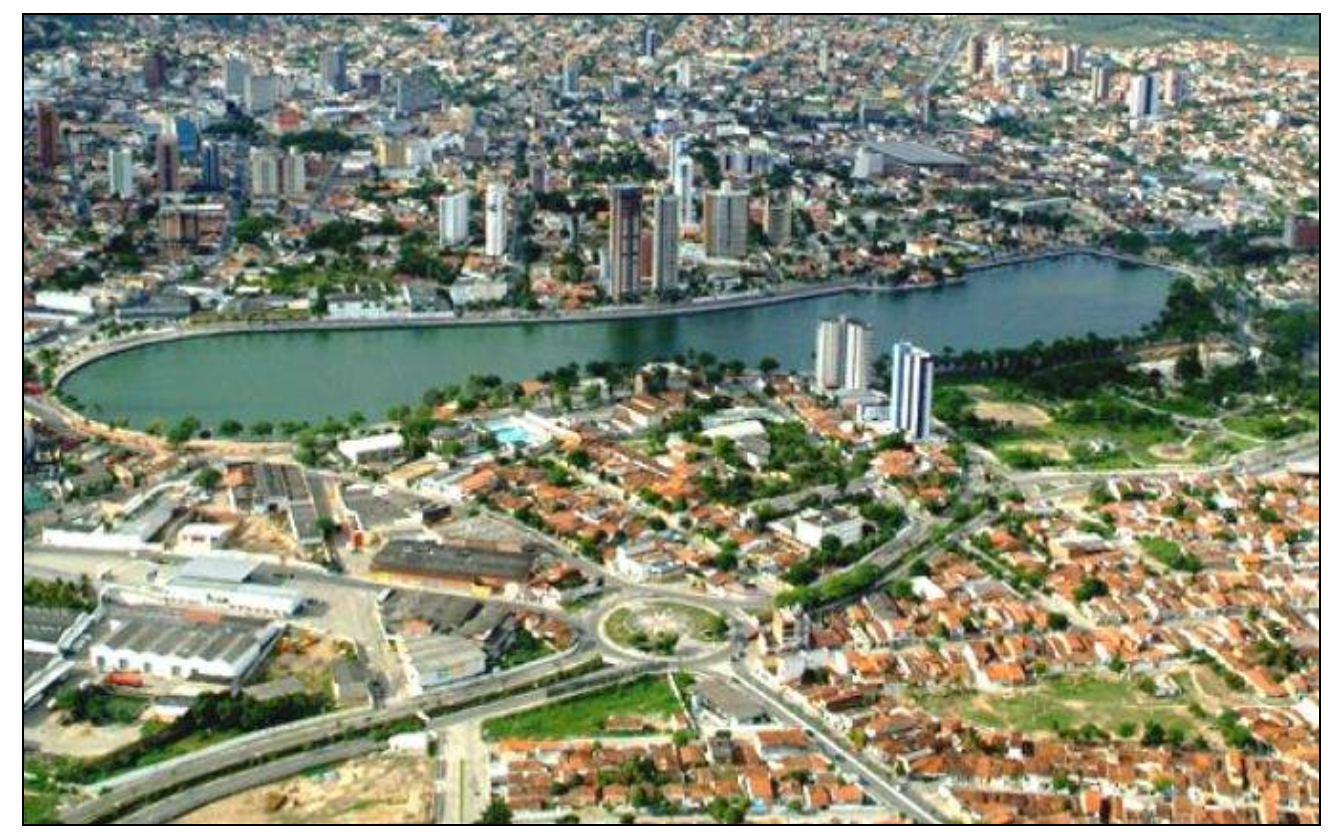

Figura 12: Vista aérea 1 de Campina Grande, Paraíba, Brasil.

Fonte: http://melhorespontosturisticos.com.br/pontos-turisticos-de-campina-grande-paraiba/.

Também possui o segundo maior PIB entre os municípios paraibanos, representando $15,63 \%$ do total das riquezas produzidas na Paraíba. Uma evidência do desenvolvimento da cidade nos últimos tempos é o ranking da revista Você S/A, no qual Campina Grande aparece como uma das 100 melhores cidades para se trabalhar e fazer carreira do Brasil, única cidade do interior entre as capitais escolhidas no país. O município é ainda considerado a cidade mais dinâmica do Nordeste e a $6^{\text {a }}$ mais dinâmica do Brasil segundo "A Gazeta Mercantil" e foi apontada como uma das 20 metrópoles brasileiras do futuro. 


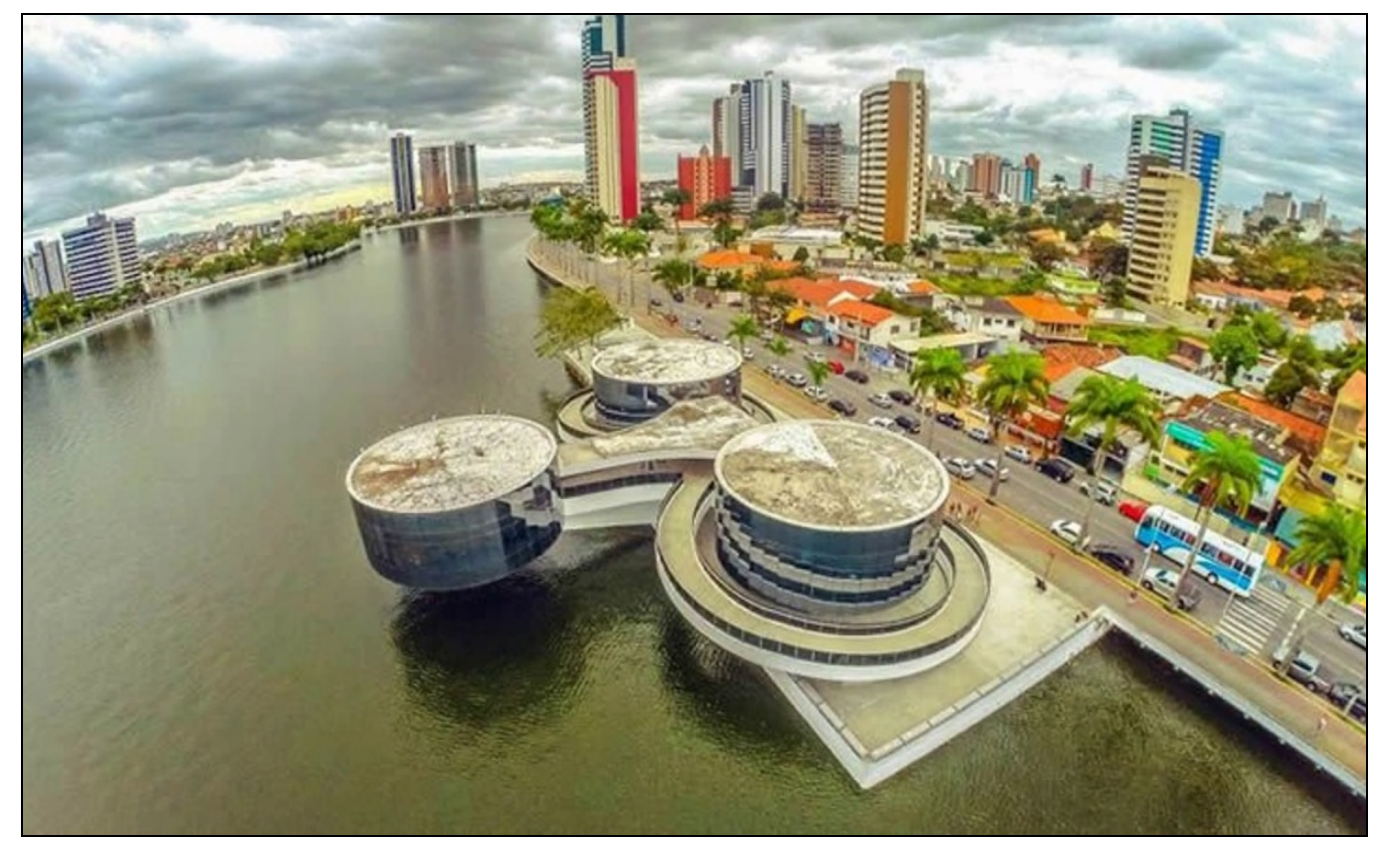

Figura 13: Vista aérea 2 de Campina Grande, Paraíba, Brasil.

Fonte: http://pmcg.org.br/campina-grande-tem-o-melhor-idh-do-semiarido-brasileiro/

O município sedia ainda variados eventos culturais, destacando-se os festejos de São João, que acontecem durante todo o mês de junho (chamado de "O Maior São João do Mundo"), encontros religiosos como o Encontro da Nova Consciência (ecumênico) e o Encontro para a Consciência Cristã (cristão), realizados durante o carnaval, além do Festival de Inverno e outros 20 eventos.

\subsubsection{A Instituição Escolar}

A pesquisa foi aplicada em duas escolas municipais de Campina Grande, cidade do estado da Paraíba: Escola Lafayete Cavalcante e Manoel da Costa Cirne, na cidade de Campina Grande, Paraíba, Brasil. 


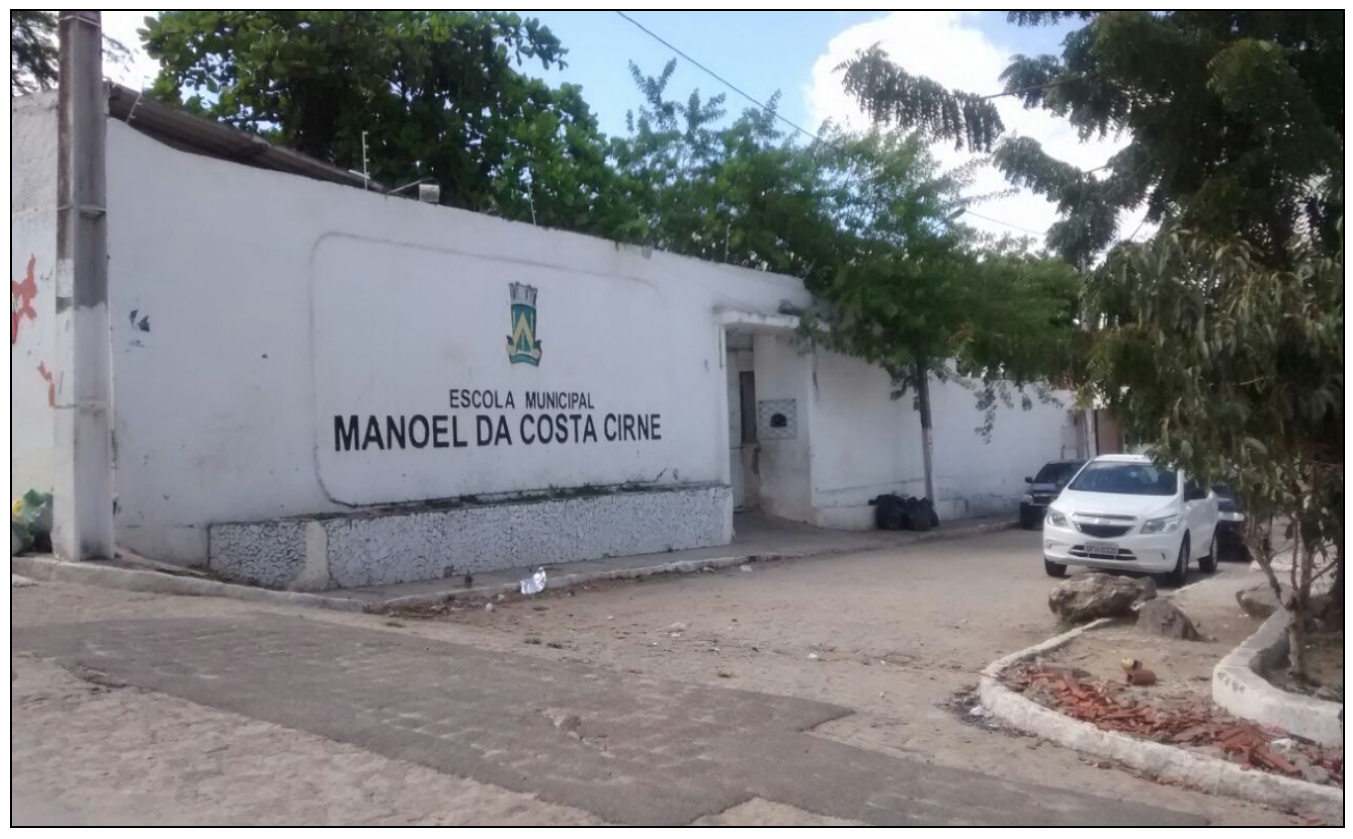

Figura 14: Faixada da Escola Municipal Manoel da Costa Cirne Fonte: elaboração própria.

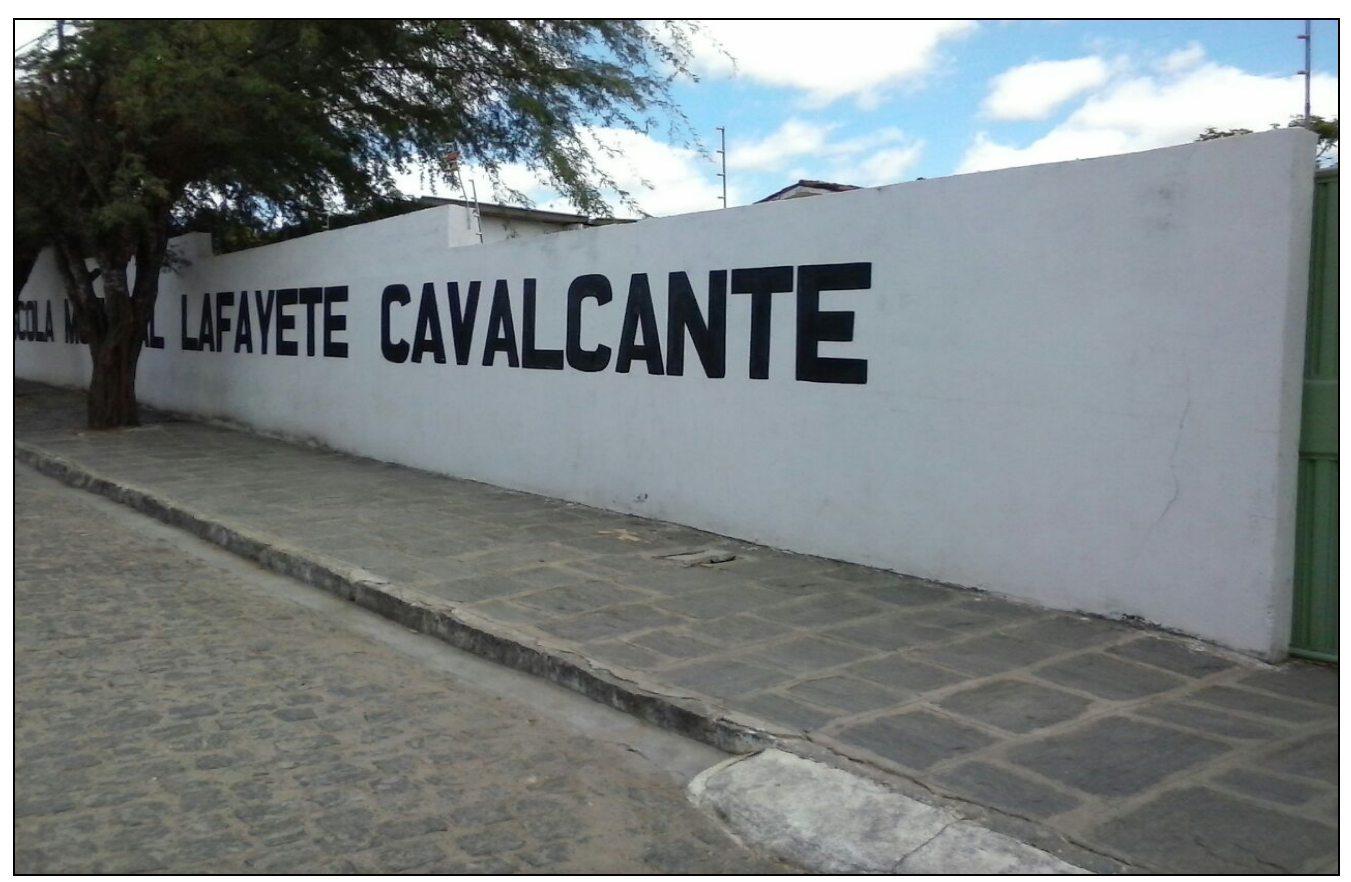

Figura 15: Faixada da Escola Municipal Lafayete Cavalcante. Fonte: elaboração própria. 


\subsection{Tipos de Investigação}

Do Tipo Descritiva: Segundo (Maia, 2010) porque o seu alcance é descrever especificamente quando e onde as propriedades, características e razões do fenômeno (acima citado) ocorrem. Segundo Kauark, Manhães e Souza (2010) "a pesquisa descritiva visa descrever as características de uma determinada população ou fenômeno ou o estabelecimento de relações entre variáveis".

Segundo Barros e Lehfeld (2010) a pesquisa descritiva permite chegar à elaboração de perfis, senários, etc. Os estudos descritivos procuram especificar as propriedades, as características e os perfis importantes de pessoas, grupos, comunidades ou qualquer outro fenômeno que se submeta a análise. Segundo Hernandez Sampieri (2010) eles medem, avaliam ou coletam dados sobre diversos aspectos, dimensões ou componentes do fenômeno a ser pesquisados.

A ênfase metodológica é quantitativa, de acordo com a pesquisa quantitativa contribui para resolver um problema em especial, os objetivos devem expressar-se com clareza para evitar possíveis desvios no processo da pesquisa quantitativa e ser susceptíveis de alcançar (Hernandez Sampieri, 2010). Isto será realizado por meio dos instrumentos: grupo de discussão, e questionário fechado baseado na escala de Likert.

Segundo Richardson (1999), caracteriza-se pelo emprego de quantificação tanto nas modalidades de coleta de informações, quanto no tratamento delas por meio de técnicas estatísticas, desde as mais simples as mais complexas como percentual. $\mathrm{O}$ pensamento Diehl (2004) também considera a pesquisa quantitativa pelo uso da quantificação, tanto na coleta de dados quanto no tratamento das informações, utilizandose técnicas estatísticas, objetivando resultados que não haja possíveis distorções de análise e interpretação, possibilitando uma maior margem de segurança.

O desenho não experimental: se realiza sem manipular deliberadamente variáveis, ou seja, se trata de estudos onde não fazemos variar em forma intencional as variáveis independentes para ver seu efeito sobre outras variáveis. De acordo com Hernandez 
Sampieri (2010) o que fazemos na pesquisa não experimental é observar fenômenos tal como se dão em seu contexto natural, para posteriormente analisá-los.

De acordo com Kerlinger (2002) apud Hernández Sampieri (2010) na investigação não experimental não é possível manipular as variáveis ou indicar aleatoriamente aos participantes ou tratamentos. De fato, não há condições ou estímulos para expor os indivíduos do estudo, eles são observados em seu ambiente natural.

\subsection{População e Amostra}

A população é a totalidade de elementos sob o estudo que apresentam uma ou mais características em comum; a amostra é uma parte da população, que tem o objetivo de tirar conclusões para o universo de onde foi retirada. A população é de 15 (quinze) professores e de 325 alunos, sendo alunos das escolas: Escolas Municipais Lafayete Cavalcante e Manoel da Costa Cirne, situadas no município de Campina Grande, Paraíba, Brasil.

Assim, os atores investigados nesse processo fazem parte de uma amostra formada por 195 (cento e noventa e cinco) alunos do Ensino Fundamental maior das escolas: Escolas Municipais Lafayete Cavalcante e Manoel da Costa Cirne, situadas no município de Campina Grande, Paraíba, Brasil.

Tabela 02: População e amostra dos alunos que participarão da pesquisa.

\begin{tabular}{lc|c}
\multicolumn{2}{c}{ População e amostra dos alunos que participarão da pesquisa. } \\
\hline População & 15 professores & 325 alunos \\
\hline Amostra & 9 professores & 195 alunos \\
\hline Total & 204 \\
\hline
\end{tabular}

Fonte: elaboração própria. 
No caso dos professores das escolas: Escolas Municipais Lafayete Cavalcante e Manoel da Costa Cirne. Trata-se de uma amostra não probabilística, pois como indica Hernandez Sampieri et al. (2010), neste tipo de amostra "a escolha dos indivíduos não depende que todos tenham a mesma probabilidade de ser escolhidos, mas da decisão de um pesquisador ou grupo de pesquisadores. Foi feito os esclarecimentos sobre a investigação durante mediante um grupo de discursão, onde o professor investigador ministrou um minicursos sobre Tecnologias Educativas, afim de esclarecer aos professores participantes questões relevantes as perguntas da entrevista e do questionário que foi aplicado.

\subsection{Instrumentos e Coleta de Dados}

Os instrumentos utilizados para a coleta de dados foram 2 (dois) questionários fechados:

1- Questionário para os alunos contando de 10 (dez)

2- Questionário fechado aplicado aos professores do ensino fundamental maior da Escolas Municipais Lafayete Cavalcante e Manoel da Costa Cirne, situadas no município de Campina Grande, Paraíba, Brasil. Um questionário consiste em um conjunto de perguntas a respeito de uma ou mais variáveis a medir (Hernandez Sampieri, 2010).

Portanto, esses instrumentos têm como objetivo fazer a caracterização do universo pesquisado, descrevendo as opiniões dos entrevistados sobre o tema específico abordado que no caso é: analisar as Contribuições das TIC à aprendizagem de matemática dos alunos das escolas municipais de Campina Grande, Paraíba, Brasil.

A Variável 1: A importância do uso das TIC nas aulas de matemática. Seus indicadores foram analisar as Contribuições das TIC à aprendizagem de matemática dos alunos das escolas municipais de Campina Grande, Paraíba, Brasil. O compartilhar de conhecimentos por meio das TIC, o desempenho do aprendizado dos conteúdos matemáticos por meio do uso das TIC. 
$A$ Variável 2: As TIC como agente motivador no aprendizado de matemática. No que corresponde a seus indicadores foram: a motivação a inovação da pratica de ensino pelos professores de matemática, a motivação no EA de matemática pelos professores e alunos das escolas citadas, o interesses por parte dos professores em usar as TIC como recursos auxiliares no EA de matemáticas.

Os instrumentos foram validados em três momentos, no primeiro pelo professor Doutor Orientador da Pesquisa; segundo momento por 5 (cinco) professores doutores especialistas na área da Educação e, no terceiro momento por uma prova piloto. No primeiro o Orientador da pesquisa fez um analise e considerações sobre os instrumentos; no segundo momento foi a aprovação dos instrumentos pelo Orientador e finalmente no quarto momento foi a validação pelos 5 (cinco) professores doutores especialistas na área da Educação, que são professores do Curso de Pós-Graduação nas modalidades Mestrado e Doutorado em Ciências da Educação ou cursos correspondentes. No Terceiro momento apresentamos para alguns alunos e professores para verificar a coesão e clareza das questões do questionário ver se estavam coerentes e de fácil entendimento para serem respondidas pelos demais professores e alunos que participaram da pesquisa.

As Técnicas e fontes de coleta de dados e parâmetros de qualidade que responde aos objetivos geral da pesquisa: Determinar a forma como melhorou o desempenho dos alunos das Escolas Municipais Lafayete Cavalcante e Manoel da Costa Cirne que estudam matemática utilizando as TIC.

Tabela 03: Tabela da Primeira Variável

\begin{tabular}{|c|c|c|c|c|}
\hline CRITÉRIOS & INDICADORES & FONTES & TECNICAS & $\begin{array}{c}\text { INSTRUME } \\
\text { NTOS }\end{array}$ \\
\hline $\begin{array}{l}\text { A contribuição dos } \\
\text { recursos tecnológicos } \\
\text { para a qualidade do } \\
\text { ensino-aprendizado de } \\
\text { matemática. }\end{array}$ & $\begin{array}{ll}\text { - } & \begin{array}{l}\text { Disponibilizam de } \\
\text { atividades }\end{array} \\
\text { motivadoras. } & \\
\text { - } & \text { Incentiva } \\
\text { interação entre os } \\
\text { alunos. } & \\
\text { - } & \text { Aplica o uso dos } \\
\text { recursos } & \\
\text { tecnológicos } & \text { na } \\
\text { realização } & \text { de } \\
\text { atividades } & \\
\text { dinâmicas. } & \end{array}$ & $\begin{array}{l}\text { Dados de } \\
\text { arquivos. }\end{array}$ & $\begin{array}{l}\text { Analises de } \\
\text { documentos } \\
\text {. }\end{array}$ & $\begin{array}{l}\text { Question } \\
\text { ário } \\
\text { fechado. }\end{array}$ \\
\hline
\end{tabular}




\begin{tabular}{|c|c|c|c|c|}
\hline $\begin{array}{l}\text { Potencialidade das TIC } \\
\text { no ensino de matemática }\end{array}$ & $\begin{array}{llr}\text { - } & \begin{array}{l}\text { Contribui para } \\
\text { desempenho }\end{array} & \text { do } \\
& \text { aprendizado } & \text { de } \\
\text { matemática. } & \\
\text { - } & \text { Aumenta } & \text { a } \\
\text { competência } & \\
\text { comunicativa } & \\
\text { interacional. } & \\
\text { - } & \text { Demonstrar } & \\
& \text { habilidade no uso } \\
& \text { dos recursos } \\
\text { tecnológicos. }\end{array}$ & $\begin{array}{l}\text { Dados de } \\
\text { arquivos. }\end{array}$ & $\begin{array}{l}\text { Analises de } \\
\text { documentos }\end{array}$ & $\begin{array}{l}\text { Questio } \\
\text { nário } \\
\text { fechado }\end{array}$ \\
\hline $\begin{array}{l}\text { O desempenho do } \\
\text { ensino-aprendizado de } \\
\text { matemática por meio das } \\
\text { TIC. }\end{array}$ & $\begin{array}{l}\text { - Motiva os alunos a } \\
\text { tomarem decisões. } \\
\text { - Favorece o raciocínio } \\
\text { lógico dos alunos. } \\
\text { - Impacta no ensino de } \\
\text { matemática. }\end{array}$ & $\begin{array}{l}\text { Dados de } \\
\text { arquivos. }\end{array}$ & $\begin{array}{l}\text { Analises de } \\
\text { documentos } \\
\text {. }\end{array}$ & $\begin{array}{l}\text { Questio } \\
\text { nário } \\
\text { fechado } \\
\text {. }\end{array}$ \\
\hline
\end{tabular}

Fonte: Elaboração própria.

\subsection{Procedimentos para Coletas de Dados}

A pesquisa foi muito bem aceita pela direção e gestão das Escolas. Tanto os diretores das Escolas como as Coordenadoras ficaram muito felizes com a proposta do pesquisador em realizar a pesquisa nas escolas: Escolas Municipais Lafayete Cavalcante e Manoel da Costa Cirne, situadas no município de Campina Grande, Paraíba, Brasil.

A direção da escola, a coordenação e professores se dispuseram a ajudar o pesquisador a aplicar os instrumentos da pesquisa. Disponibilizaram de tempo para que a aplicação dos questionários fossem aplicados, embora tivemos alguns contratempos, que é normal acontecer isso. Foi muito gratificante o apoio de todos no desenvolvimento da pesquisa, pois sem a participação dos mesmos a pesquisa não seria concluída e nem tão bem sucedida.

No primeiro momento foi aplicado o questionário na Escola Municipal Lafayete Cavalcante: o questionário fechado foi aplicado primeira semana do mês de março de 2018 para os professores, em seguida para os alunos. Antes de aplicar os questionários o 
pesquisado conscientizou os participantes sobre a importância da pesquisa e sua futura contribuição para o crescimento da escola.

Depois no segundo momento, aplicação do questionário na Escola Manoel da Costa Cirne: o questionário fechado foi aplicado na segunda semana do mês de marco de 2018 seguindo os mesmos procedimentos usados na aplicação na escola anterior.

Aplicado os questionários nas duas escolas e, recolhidos. O pesquisador passou ao analises dos instrumentos seguindo os seguintes passos:

- Foi feito um levantamento geral dos dados dos questionários recolhidos nas escolas;

- O pesquisador passou a fazer os gráficos (por meio do programa Excell2017), referentes a cada pergunta dos questionários (dos professores e alunos), preparando assim os resultados para serem discutidos;

- Depois de realizado cada gráfico com os referidos resultados foram representado em porcentagem, o pesquisador fez a discursão de cada resultado.

Estes foram os procedimentos usados no processo do analises e discussão dos resultados da pesquisa.

O pesquisador se propôs a dar o resultado da pesquisa para os professores participantes da pesquisa, depois que culminar com a defesa do doutorado, e assim que dispor de tempo para apresentar-se nas escolas participantes da pesquisa. 


\section{ANALISES E DISCUSSÃO DOS RESULTADOS}

Passando as analises dos instrumentos aplicados aos sujeitos da pesquisa intitulada: a analisar as Contribuições das TIC à aprendizagem de matemática dos alunos das escolas municipais de Campina Grande, Paraíba, Brasil. A pesquisa foi realizada com alunos e professores das escolas: Escolas Municipais Lafayete Cavalcante e Manoel da Costa Cirne, situadas no município de Campina Grande, Paraíba, Brasil.

Os questionários fechados foram elaborados com a finalidade de responderem aos objetivos específicos da pesquisa. Os objetivos específicos da pesquisa que são: 1) Estimar a diferença no rendimento acadêmico dos alunos que têm acesso às TIC aos que não têm acesso; 2) Verificar se índices de aprovação e reprovação pode ser influenciado pelo uso das TIC nas escolas; 3)Estabelecer se os alunos se sentiram mais estimulados a estudar matemática utilizando as TIC. Resultados do questionário aplicado aos alunos das escolas: Escolas Municipais Lafayete Cavalcante e Manoel da Costa Cirne, situadas no município de Campina Grande, Paraíba, Brasil.

7.1. Dados sobre os participantes (sujeitos) da pesquisa.

Os participantes da pesquisa foram os professores da disciplina de Matemática e os alunos do $6^{\circ}, 7^{\circ}, 8^{\circ}$ e $9^{\circ}$ ano do Ensino Fundamental das Escolas Municipais Lafayete Cavalcante e Manoel da Costa Cirne, situadas no município de Campina Grande, Paraíba, Brasil.

Buscamos aqui demonstrar o perfil dos professores de matemática que atuam no Ensino Fundamental Maior (do $6^{\circ}$ ao $9^{\circ}$ ano) da Escola A - Escolas Municipais Lafayete Cavalcante: 
Tabela 04: Perfil dos professores da Escola Municipal Lafayete Cavalcante município de Campina Grande, Paraíba, Brasil..

\begin{tabular}{|c|c|c|c|}
\hline \multicolumn{4}{|c|}{$\begin{array}{r}\text { Dados dos professores da Escola Municipal Lafayete Cav } \\
\text { Paraíba, Brasil. }\end{array}$} \\
\hline Quantidade de professores & 5 professores & & \\
\hline Sexo dos professores & Masculino $=4$ & Feminino $=1$ & Total $=5$ \\
\hline Idade dos professores & $\begin{array}{c}\text { Masculinos }=\text { entre } 35 \\
\text { a } 57 \text { anos }\end{array}$ & $\begin{array}{c}\text { Feminino }=\text { entre } 30 \mathrm{a} \\
50 \text { anos }\end{array}$ & \\
\hline Grau de formação & $\begin{array}{l}\text { Professores }=\text { todos } \\
\quad \text { especialistas }\end{array}$ & $\begin{array}{l}\text { Professoras }=\text { todas } \\
\quad \text { especialistas }\end{array}$ & \\
\hline Tempo de atuação profissional & $\begin{array}{l}\text { Entre } 10 \text { a } 22 \text { anos de } \\
\text { atuação docente }\end{array}$ & & \\
\hline
\end{tabular}

Fonte: elaboração própria.

Os professores da Escola Municipal Lafayete Cavalcante tem um perfil bastante variável. Temos professores com a idade de 35 a 57 anos de idades. Professores do sexo masculino e feminino, jovens e professores que já estão com idade mais avançada e próximos de se aposentarem. É interessante que todos os professores tem uma Especialização.

No Brasil não é comum as mulheres fazerem Licenciatura em Matemática, além de ser considerada uma disciplina muito difícil tanto para aprender nas escolas como para os jovens se formarem (obter um titulo superior em Matemática). Também encontramos relacionado aos cursos de Licenciatura em Matemática uma defasagem muito grande nas salas de aulas das universidades. Turmas de licenciaturas com 4 a 9 alunos e, muitas das vezes não concluem o curso 4 alunos. 
Sobre o perfil dos alunos da Escola Municipal Lafayete Cavalcante município de Campina Grande, Paraíba, Brasil temos:

Tabela 05: Perfil dos alunos da Escola Municipal Lafayete Cavalcante município de Campina Grande, Paraíba, Brasil..

\begin{tabular}{|c|c|c|c|c|}
\hline \multicolumn{5}{|c|}{$\begin{array}{l}\text { Perfil dos alunos da Escola Municipal Lafayete Cavalca } \\
\text { Paraíba, Brasil. }\end{array}$} \\
\hline Dados & $6^{\circ}$ ano & $7^{\circ}$ ano & $8^{\circ}$ ano & $9^{\circ}$ ano \\
\hline Quantidade & 25 & 24 & 24 & 25 \\
\hline Idade & $\begin{array}{c}\text { Alunos de } 12 \text { a } 13 \\
\text { anos de idade }\end{array}$ & $\begin{array}{c}\text { Alunos de } 13 \text { a } 14 \\
\text { anos de idade }\end{array}$ & $\begin{array}{l}\text { Alunos de } 14 \text { a } 15 \\
\text { anos de idade }\end{array}$ & $\begin{array}{l}\text { Alunos de } 15 \text { a } 16 \\
\text { anos de idade }\end{array}$ \\
\hline Sexo & $\begin{array}{l}\text { Masculino }=20 \% \\
\text { Feminino }=80 \%\end{array}$ & $\begin{array}{l}\text { Masculino }=18 \% \\
\text { Feminino }=82 \%\end{array}$ & $\begin{array}{c}\text { Masculinos }=25 \% \\
\text { Feminino }=75 \%\end{array}$ & $\begin{array}{c}\text { Masculino }=18 \% \\
\text { Feminino }=82 \%\end{array}$ \\
\hline
\end{tabular}

Fonte: Elaboração própria.

O perfil dos alunos Escola Municipal Lafayete Cavalcante do Ensino Fundamental Maior, relacionados à disciplina de Matemática. Participaram da pesquisa alunos do $6^{\circ}$ ano ao $9^{\circ}$ ano do Ensino Fundamental Maior e, alunos com idade entre 12 de idade a 16 anos de idade. Em relação ao sexo dos alunos temos uma maior porcentagem de alunos do sexo feminino e menor do sexo masculino. Nas escolas Municipais da relativa cidade onde foi aplicada a pesquisa temos um número limitado de vagas para alunos. As escolas não recebem alunos acima da cota estabelecida pelo Município. Sobre a faixa etária dos alunos é importante relatar que a idade normal para os alunos cursarem os anos: $6^{\circ}$ ano é de 12 anos de idade; o $7^{\circ}$ ano é de 13 anos de idade; o $8^{\circ}$ ano é de 14 anos de idade e o $9^{\circ}$ ano é de 16 anos de idades. Como temos os repetentes a faixa etária oscila de acordo o demonstrado na tabela acima. 
Demonstrando o perfil dos professores de matemática do Ensino Fundamental Maior ( $6^{\circ}$ ao $9^{\circ}$ ano) da Escola Municipal Manoel da Costa Cirne, Campina Grande, Paraíba, que participaram da pesquisa temos a tabela seguinte:

Tabela 06: Perfil dos professores da Escola Municipal Manoel da Costa Cirne, Campina Grande, Paraíba, Brasil.

\begin{tabular}{|c|c|}
\hline & Dados dos professores da Escola Municipal Manoel da Costa Cirne, Campina Grande, Paraíba, \\
\hline Quantidade de professores & 4 professores \\
\hline Sexo dos professores & Todos masculinos \\
\hline Idade dos professores & Entre 40 a 59 anos de idade \\
\hline Grau de formação & Todos tem especialização \\
\hline Tempo de atuação profissional & Entre 10 anos a 20 anos de atuação docente \\
\hline
\end{tabular}

Fonte: elaboração própria.

A escola Municipal é uma escola pequena onde recebe poucos alunos e consequentemente tem um menor numero de professores. Os professores são todos do sexo masculino, todos tem uma Especialização e estão na faixa etária de 40 anos de idade a 59 anos. É importante ressaltar o tempo de experiência de docência sendo que todos tem um grau de experiência relativamente muito bom. 
Passando ao perfil dos alunos da Escola Municipal Manoel da Costa Cirne, Campina Grande, Paraíba temos que:

Tabela 07: Perfil dos alunos da Escola Municipal Manoel da Costa Cirne, Campina Grande, Paraíba, Brasil.

\begin{tabular}{|c|c|c|c|c|}
\hline \multicolumn{5}{|c|}{ Perfil dos alunos da Escola Municipal Manoel da Costa Cirne, Campina Grande, Paraíba, Brasil. } \\
\hline Dados & $6^{\circ}$ ano & $7^{\circ}$ ano & $8^{\circ}$ ano & $9^{\circ}$ ano \\
\hline Quantidade & 25 & 24 & 24 & 24 \\
\hline Idade & $\begin{array}{l}\text { Alunos de } 12 \text { a } 13 \\
\text { anos de idade }\end{array}$ & $\begin{array}{c}\text { Alunos de } 13 \text { a } 14 \\
\text { anos de idade }\end{array}$ & $\begin{array}{c}\text { Alunos de } 14 \text { a } 15 \\
\text { anos de idade }\end{array}$ & $\begin{array}{c}\text { Alunos de } 15 \text { a } 16 \\
\text { anos de idade }\end{array}$ \\
\hline Sexo & $\begin{array}{l}\text { Masculino }=20 \% \\
\text { Feminino }=80 \%\end{array}$ & $\begin{array}{l}\text { Masculino }=18 \% \\
\text { Feminino }=82 \%\end{array}$ & $\begin{array}{c}\text { Masculinos }=25 \% \\
\text { Feminino }=75 \%\end{array}$ & $\begin{array}{c}\text { Masculino }=18 \% \% \\
\text { Feminino }=82 \%\end{array}$ \\
\hline
\end{tabular}

Fonte: Elaboração própria.

Como podemos ver o perfil dos alunos da Escola Municipal Manoel da Costa Cirne temos que: participaram da pesquisa 97 alunos; a faixa etária dos alunos está entre os 12 anos de idade ao 16 anos; na maioria os alunos que participaram foram do sexo feminino e a minoria do sexo masculino.

Estes foram os perfis dos professores e alunos do Ensino Fundamental Maior da Escola Municipal Manoel da Costa Cirne, Campina Grande, Paraíba, Brasil. 
7.2. Analises do questionário fechado aplicado aos alunos

O questionário fechado aplicado aos alunos buscou responder o terceiro objetivo especifico da pesquisa que é: Estabelecer se os alunos se sentiram mais estimulados a estudar matemática utilizando as TIC. Resultados do questionário aplicado aos alunos das escolas: Escolas Municipais Lafayete Cavalcante e Manoel da Costa Cirne, situadas no município de Campina Grande, Paraíba, Brasil.

Gráfico 01: Como você se sente quando o professor usa as TIC nas aulas de matemática?

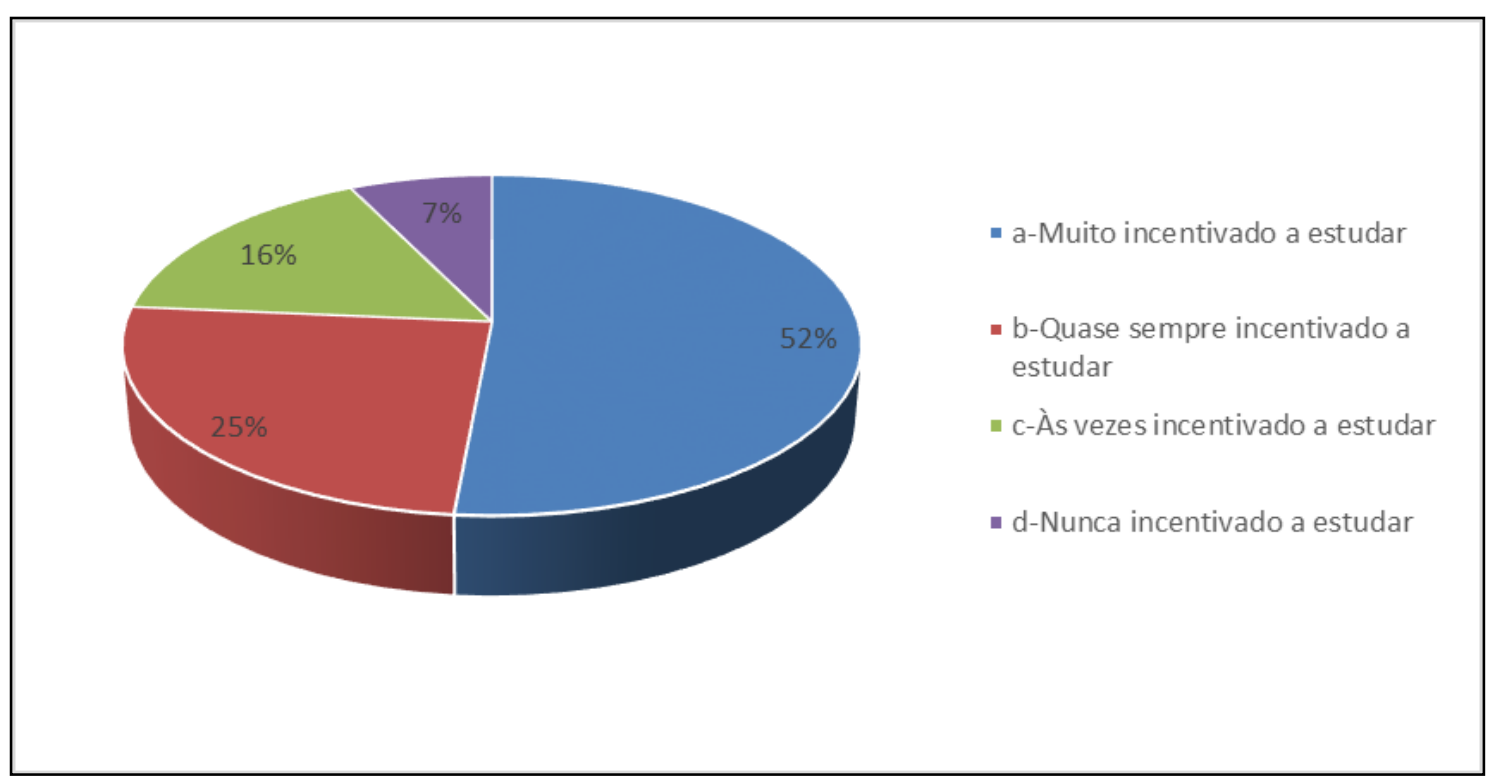

Fonte: dados da pesquisa.

Analisando a primeira pergunta do questionário aplicado aos alunos. Obtivemos as seguintes respostas: $52 \%$ dos alunos entrevistados responderam que se sentem muito incentivados a estudar, e somente 7\% dos alunos responderam que nunca se sentem incentivados a estudar. Como podemos observar as respostas acima se conclui que as TIC incentivam muito os alunos a estudarem os conteúdos de matemática. 
Gráfico 02: Como você ver as aulas de matemática quando o professor usa os recursos tecnológicos para ensinar os conteúdos?

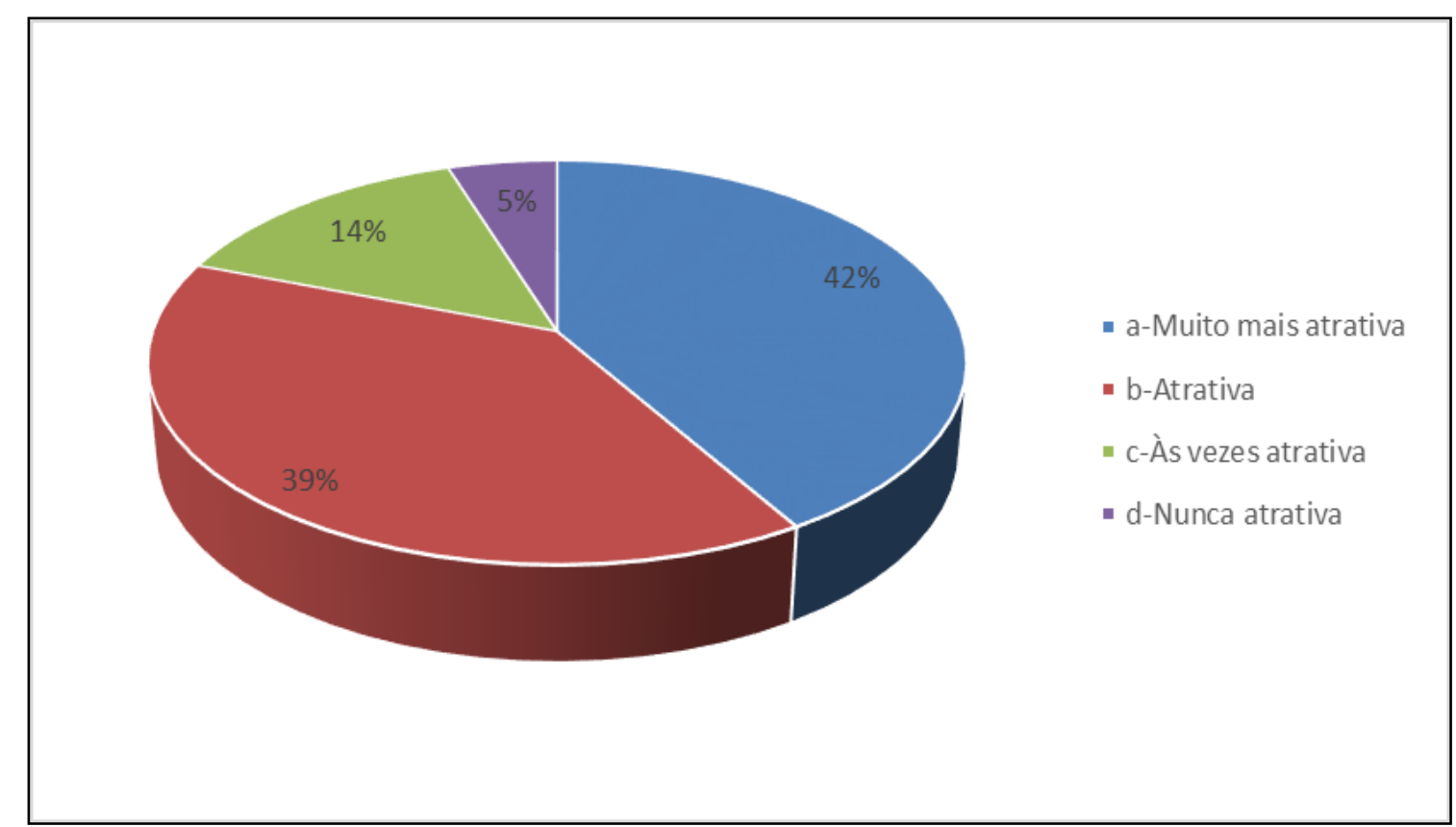

Fonte: dados da pesquisa.

Passando a analisar a segunda pergunta do questionário temos que: $42 \%$ dos alunos responderam que as aulas de matemática ficam muito mais atrativas com o uso dos recursos tecnológicos, e somente 5\% dos alunos responderam que não ficam nunca ficam atrativas as aulas de matemáticas com os usos dos recursos tecnológicos. Aqui vemos que os recursos tecnológicos usados pelos professores tem grande respaldo nas aulas de matemática, os mesmo, favorecem mais atração das atividades aplicadas aos alunos. Hoje tudo aquilo que se pode usar para favorecer o desenvolvimento da pratica pedagógica é de grande importância para o crescimento do aprendizado dos alunos e também para o trabalho do professor em sala de aula.

Segundo Borba et all (2014) tentamos ver a tecnologia como uma marca do nosso tempo, que constrói e é construída pelo ser humano. A noção de seres-humanos-com-mídia tenta enfatizar que vivemos sempre em conjunto de humanos e que somos frutos de um momento histórico, que tem as tecnologias historicamente definidas como copartícipes dessa busca pela educação. As tecnologias digitais são parte do processo de educação do ser humano, e também partes constituintes da incompletude e da superação dessa incompletude ontológica do ser humano. 
Com as TIC e seus benefícios os professores têm hoje de criar novos contextos de aprendizagem em sala de aula. Os alunos do século XXI estão estafados da velha prática onde o professor só trabalha conteúdos na base de livros e textos monótonos, agora os alunos têm diversas opções para aprender por meio das TIC.

Gráfico 03: O professor tem usado muito as TIC para ensinar os conteúdos em sala de aula?

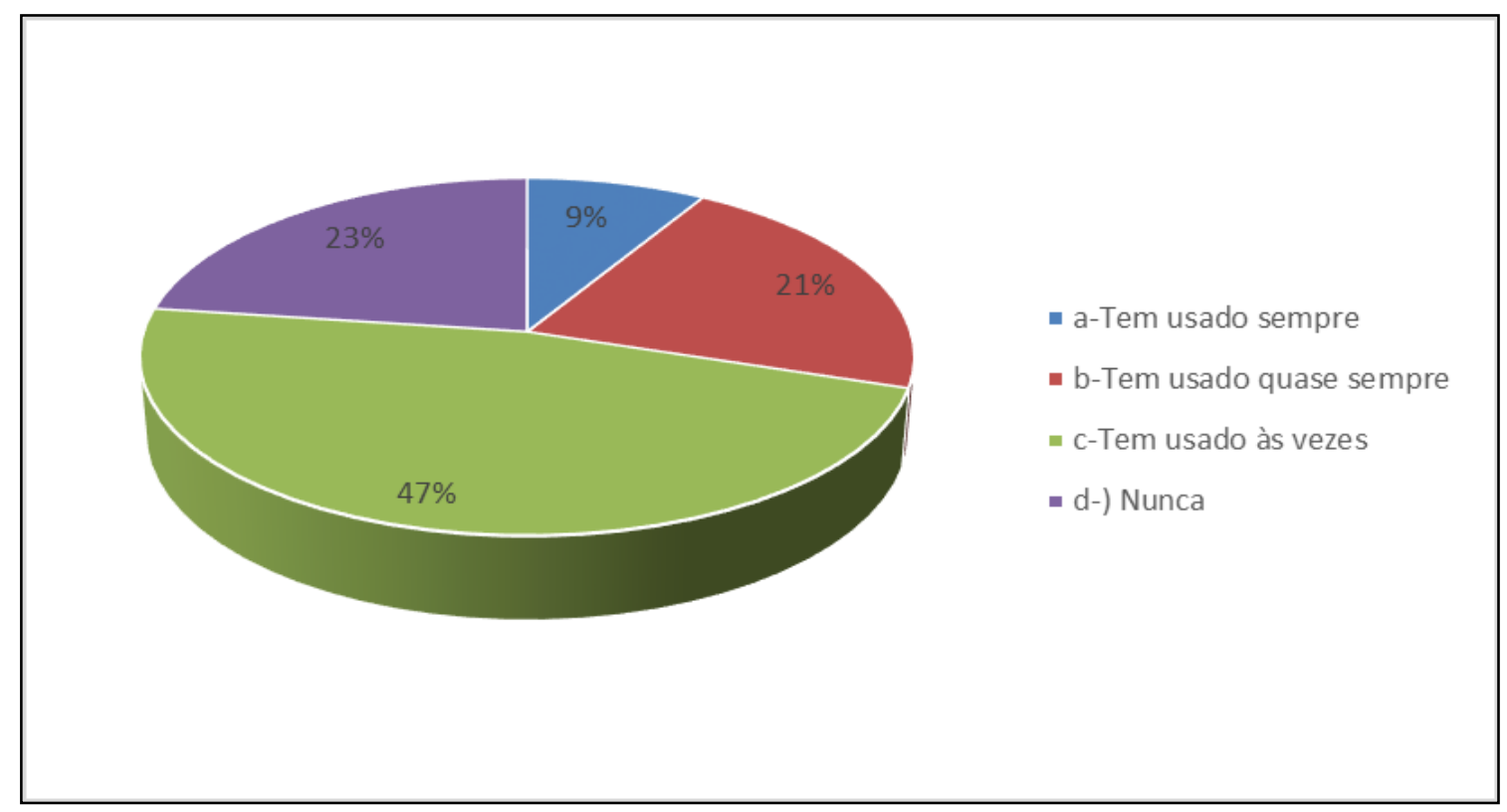

Fonte: estudo da pesquisa.

Analisando a terceira pergunta do questionário, gráfico 03, aplicado aos alunos temos que: $47 \%$ dos alunos responderam que têm usados às vezes as TIC para ensinar os conteúdos em sala de aulas de matemática, e somente $9 \%$ dos alunos responderam que tem usado sempre as TIC para ensinar os conteúdos em sala de aulas de matemática. Como se pode observar as respostas dadas pelos alunos, vemos que a situação é crítica diante da realidade que vivemos hoje com o desenvolvimentos das TIC. Somente $9 \%$ dos alunos confirmam que os professores usam as TIC nas suas aulas.

Analisando as respostas da quarta pergunta, gráfico 04, direcionada aos alunos temos que: $33 \%$ dos alunos responderam que sempre as aulas de matemática se tornaram mais interessantes com o uso dos recursos tecnológicos pelo seus professor e, somente $5 \%$ dos alunos responderam que nunca as aulas de matemática se tornaram mais interessantes com o uso dos recursos tecnológicos. 
Gráfico 04: As aulas de matemática se tornaram mais interessantes com o uso dos recursos tecnológicos pelo seus professor?

Fonte: dados da pesquisa.

Observando as respostas do gráfico acima, uma porcentagem significante confirma que os recursos tecnológicos tornam as aulas de matemática mais interessantes, mas para que isso aconteça o professor tem que ter conhecimento não somente destes recursos como também das suas funcionalidades que possibilitará o melhor uso dos mesmo recursos e, com isso levar aos alunos a importância de se aprender os conteúdos matemático com o auxílios dos recursos tecnológicos.

Segundo Borba (2014) nesse sentido o uso de recursos tecnológicos nas aulas de Matemática, em especial no ensino da geometria, pode promover alterações na estrutura da sala de aula e também na maneira de ensinar e de aprender os conteúdos. Portanto, os professores precisam conhecer as possibilidades e também os limites das tecnologias, estando preparados para utilizá-las como apoio ao processo de ensino e aprendizagem. 
Gráfico 05: As atividades de matemática ministradas por meios dos Recursos Tecnológicos têm melhorado seu desempenho no aprendizado dos conteúdos?

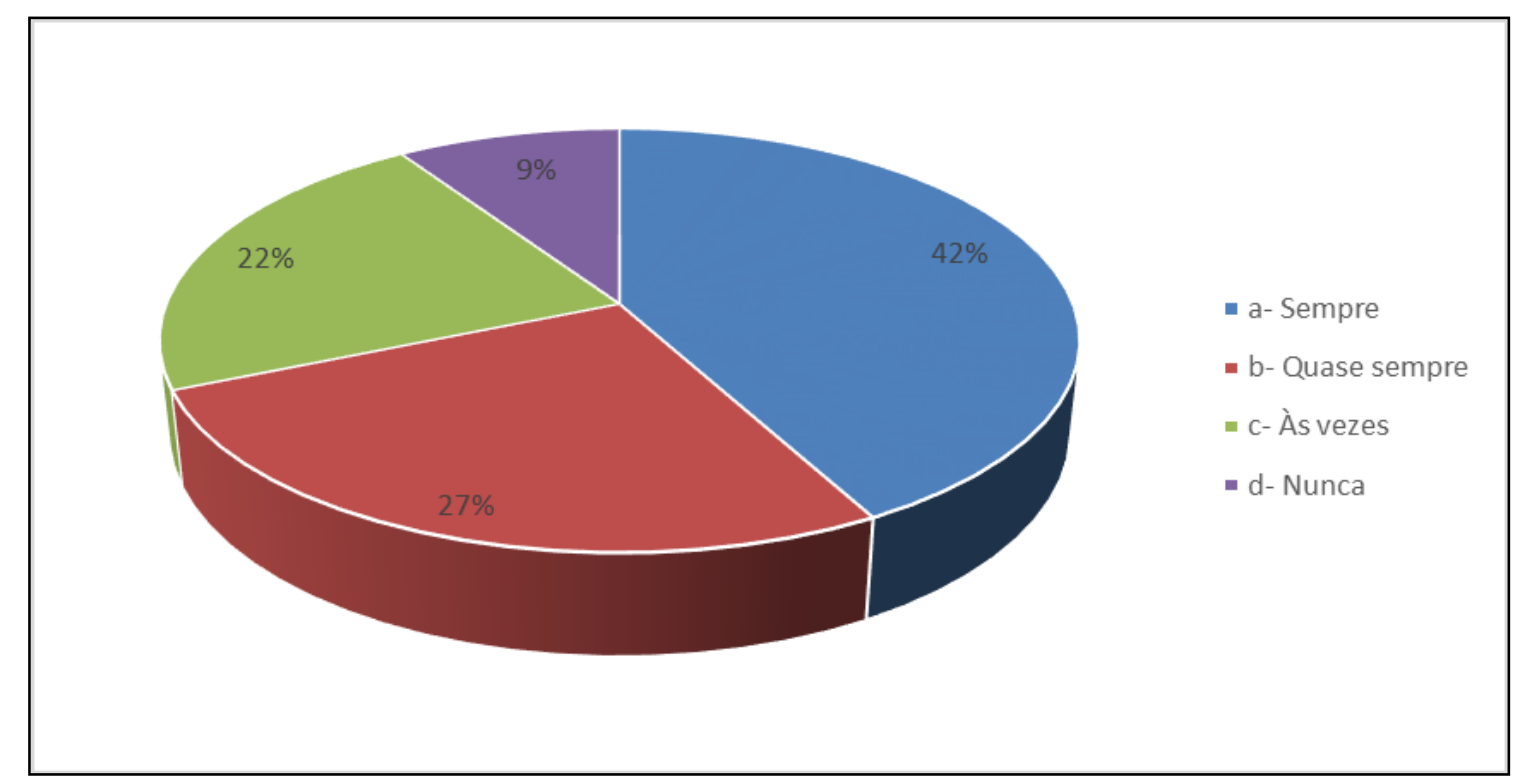

Fonte: dados da pesquisa.

Passando a analisar as respostas da quinta pergunta do questionário, gráfico 05 , aplicado aos alunos temos que: $42 \%$ dos alunos entrevistados responderam que sempre as atividades de matemática ministradas por meios dos Recursos Tecnológicos têm melhorado seu desempenho no aprendizado dos conteúdos e somente $9 \%$ dos alunos entrevistados responderam que nunca as atividades de matemática ministradas por meios dos Recursos Tecnológicos têm melhorado seu desempenho no aprendizado dos conteúdos. Como podemos perceber as atividades de matemáticas ministradas por meio de recursos tecnológicos ganham potencialidade, os alunos passam a aprender mais, o professor obtém êxito na aplicação das atividades.

Analisando a sexta pergunta do questionário, gráfico 06, dada pelos resultados do gráfico 6 temos que: dos alunos entrevistados 43\% responderam que sempre se sentem mais estimulado com o uso dos recursos tecnológicos no auxílio das atividades de matemática e apenas $6 \%$ responderam que nunca se sentem mais estimulado com o uso dos recursos tecnológicos no auxílio das atividades de matemática. Sobre a referida questão é bom ressaltar que o professor tem que se empenhar a trabalhar mais com os recursos 
tecnológicos e demonstrar para os alunos o valor da utilização dos mesmo para o melhor aprendizado dos conteúdos ministrados.

Gráfico 06: Você se sente mais estimulado com o uso dos recursos tecnológicos no auxílio das atividades de matemática?

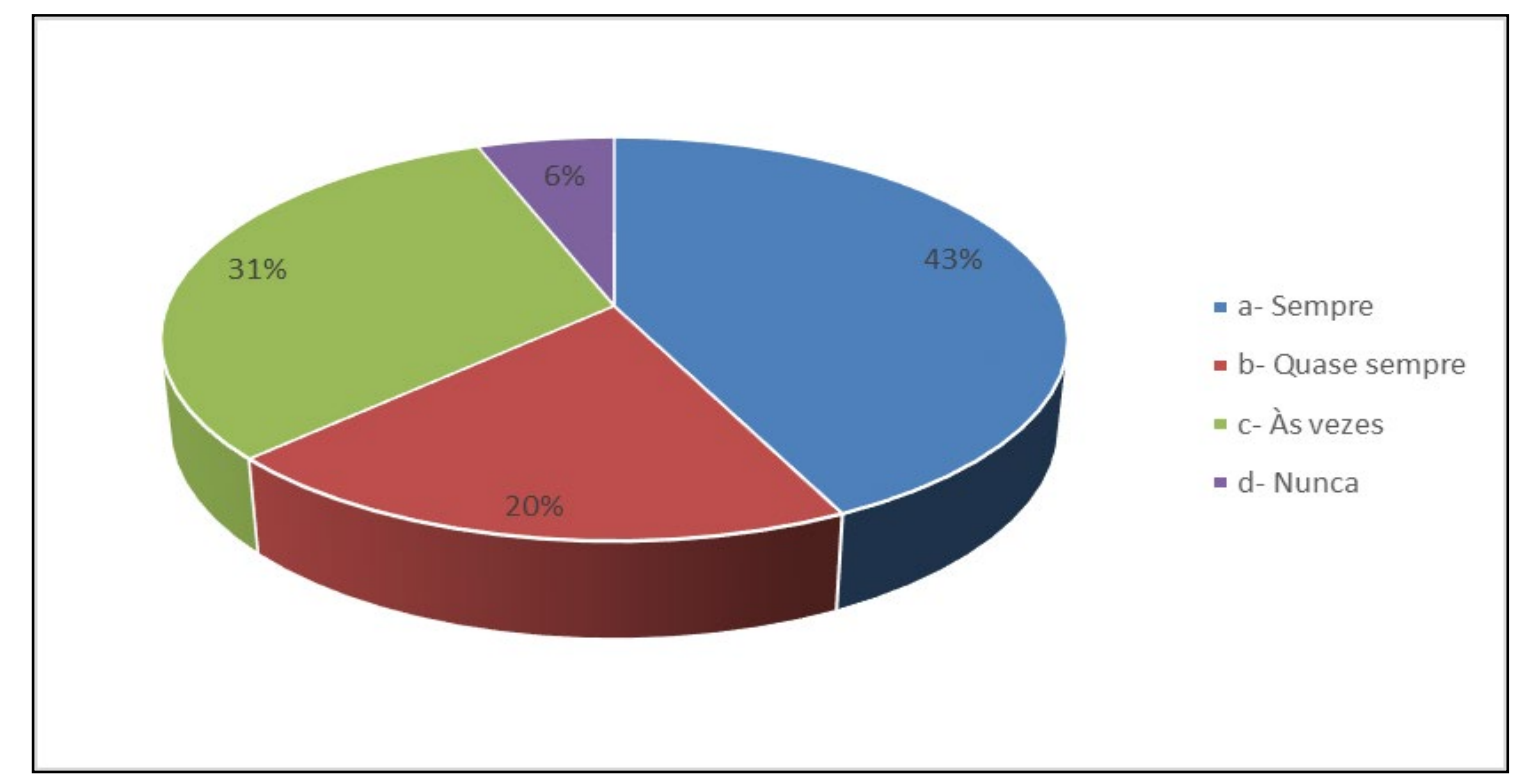

Fonte: dados da pesquisa.

Para Kenski (2007) com o intuito de viabilizar a comunicação, o homem durante sua história e evolução produziu um tipo especial de tecnologia, chamada por alguns autores de "tecnologia de inteligência". Baseada na existência, não como máquina, mas como linguagem e considerada imaterial. Para disseminar essa inteligência em diferentes tempos e espaços, foram sendo desenvolvidos aleatoriamente inúmeros processos e produtos.

Como citado acima as TIC é essa "tecnologia de inteligência" que favorece o desenvolvimento do ensino-aprendizado de matemática. Dando aos professores novos recursos para dinamizar suas aulas e repassar os conteúdos com mais eficácia para os alunos. 
Gráfico 07: Com a inclusão do uso da TIC nas aulas de matemáticas você tem percebido avanço no aprendizado?

Fonte: dados da pesquisa.

Analisando o gráfico 7 que se refere a sétima questão do questionário aplicado aos alunos temos que: $44 \%$ dos alunos entrevistados responderam que sempre têm percebido a inclusão do uso da TIC nas aulas de matemáticas avanço no aprendizado e, somente 2\% responderam que nunca têm percebido a inclusão do uso da TIC nas aulas de matemáticas avanço no aprendizado.

Segundo Siemens (2004) a inclusão da tecnologia e, a identificação de conexões como atividades de aprendizagem, começa a mover as teorias de aprendizagem por volta da idade digital. Já não é possível experimentar e adquirir pessoalmente a aprendizagem que necessitamos para atuar.

Passando a analisar a oitava pergunta, referente aos resultados do gráfico 8 temos que: $51 \%$ dos alunos entrevistados responderam que as aulas de matemática ficam muito mais atraentes com o uso dos recursos tecnológico pelo seu professor e, apenas 6\% dos alunos responderam que nunca as aulas de matemática ficam atraentes com o uso dos recursos tecnológico pelo seu professor. Como podemos ver a maioria dos alunos confirmam que as aulas de matemática ficam mais atraentes quando o professor usa os recursos tecnológicos. 
Gráfico 08: As aulas de matemática ficaram mais atraentes com o uso dos recursos tecnológico pelo seu professor (a)?

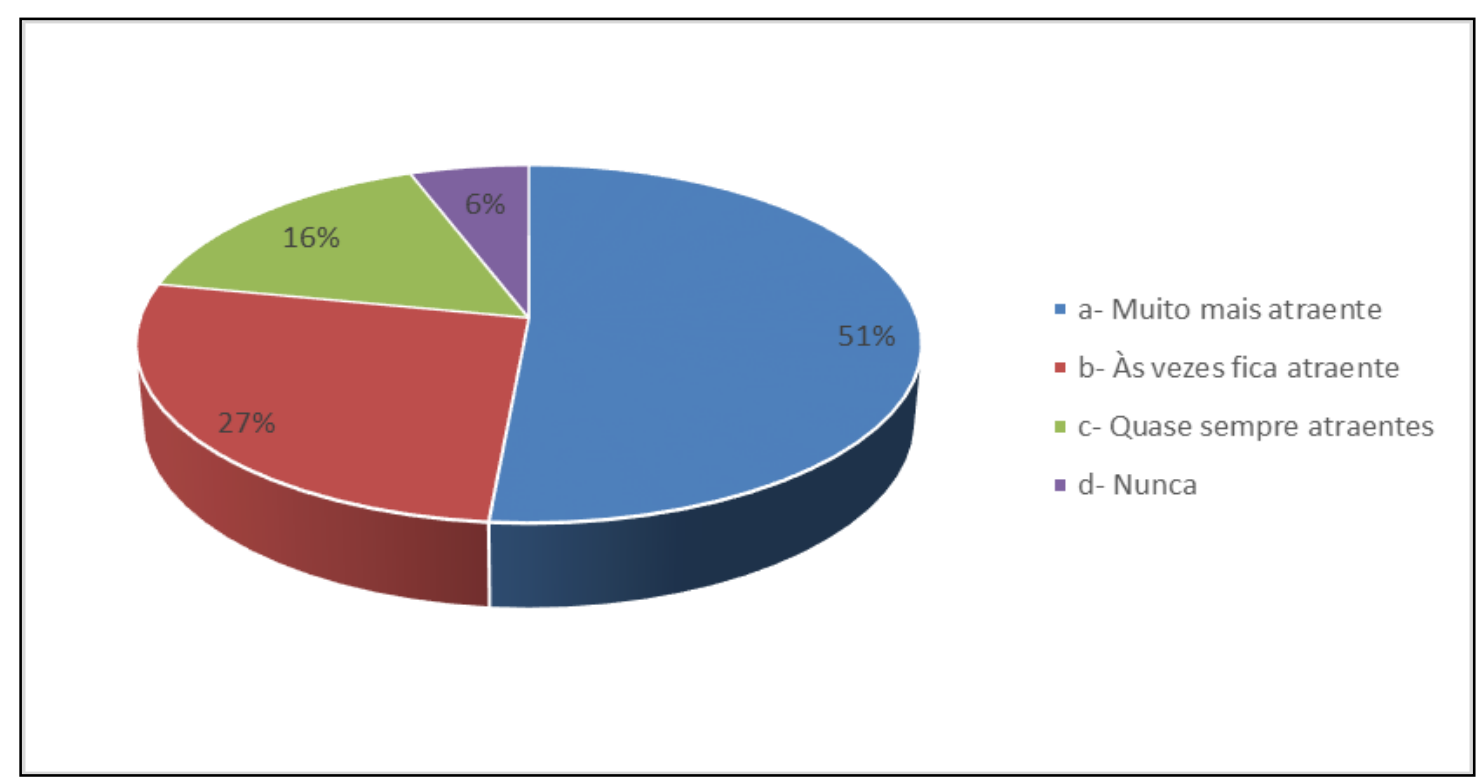

Fonte: dados da pesquisa.

Para Kenski (2007) as tecnologias invadem nossas vidas, ampliam a nossa memória, garantem novas possibilidades de bem-estar e fragilizam as capacidades naturais do ser humano. Somos muito diferentes dos nossos antepassados e nos acostumamos com alguns confortos tecnológicos- água encanada, luz elétrica, fogão, sapatos, telefone - que nem podemos imaginar como seria viver sem eles.

Passando a analisar a nona pergunta, referente aos resultados do gráfico 9 temos que: $37 \%$ dos alunos entrevistados responderam que os professores incentivam muito a usar mais as TIC para melhorar o aprendizado dos conteúdos de matemática e somente $7 \%$ dos alunos responderam que nunca os professores incentivam a usar mais as TIC para melhorar o aprendizado dos conteúdos de matemática. Como se pode comprovar segundo as respostas dos alunos os professores precisam incentivar mais os alunos ao uso dos recursos tecnológicos com a finalidade de realizarem as atividades matemáticas. 
Gráfico 09: O professor sempre incentiva a classe usar mais as TIC para melhorar o aprendizado dos conteúdos de matemática?

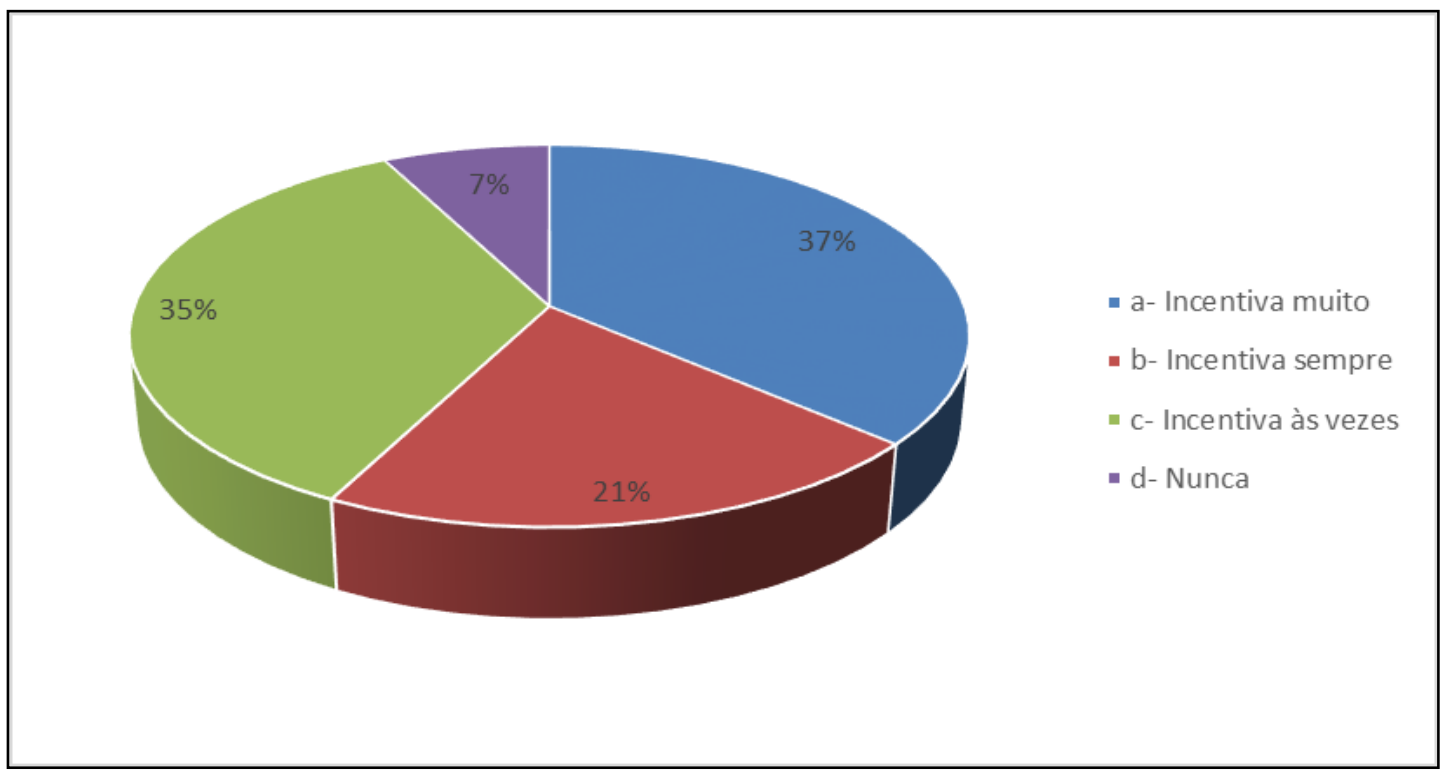

Fonte: dados da pesquisa.

Chaves (1998) considera que a escola precisa mudar, se quiser sobreviver como instituição educacionalmente relevante. Ela precisa se voltar para a criação de ambientes virtuais ricos em possibilidades de aprendizagem, nos quais as pessoas possam desenvolver as habilidades e competências que lhes permitam dominar os processos por meio dos quais possam ser capazes de aprendizagem permanente e constante.

Passando a analisar decima pergunta, dos resultados do gráfico 10 temos que: $42 \%$ dos alunos entrevistados responderam que o uso das TIC mudou muito o seu interesse pelo aprendizado da disciplina de matemática e somente 13\% dos alunos responderam que o uso das TIC nunca mudou o seu interesse pelo aprendizado da disciplina de matemática.

Como podemos ver, o uso das TIC em sala de aula enriquece o ensino-aprendizado de matemática. Ativa o interesse dos alunos a realizarem as atividades aplicadas pelos professores. Esse é um dos benefícios que as TIC favorecem aos alunos. 
Gráfico 10: O uso das TIC tem mudado seu interesse pelo aprendizado da disciplina de matemática?

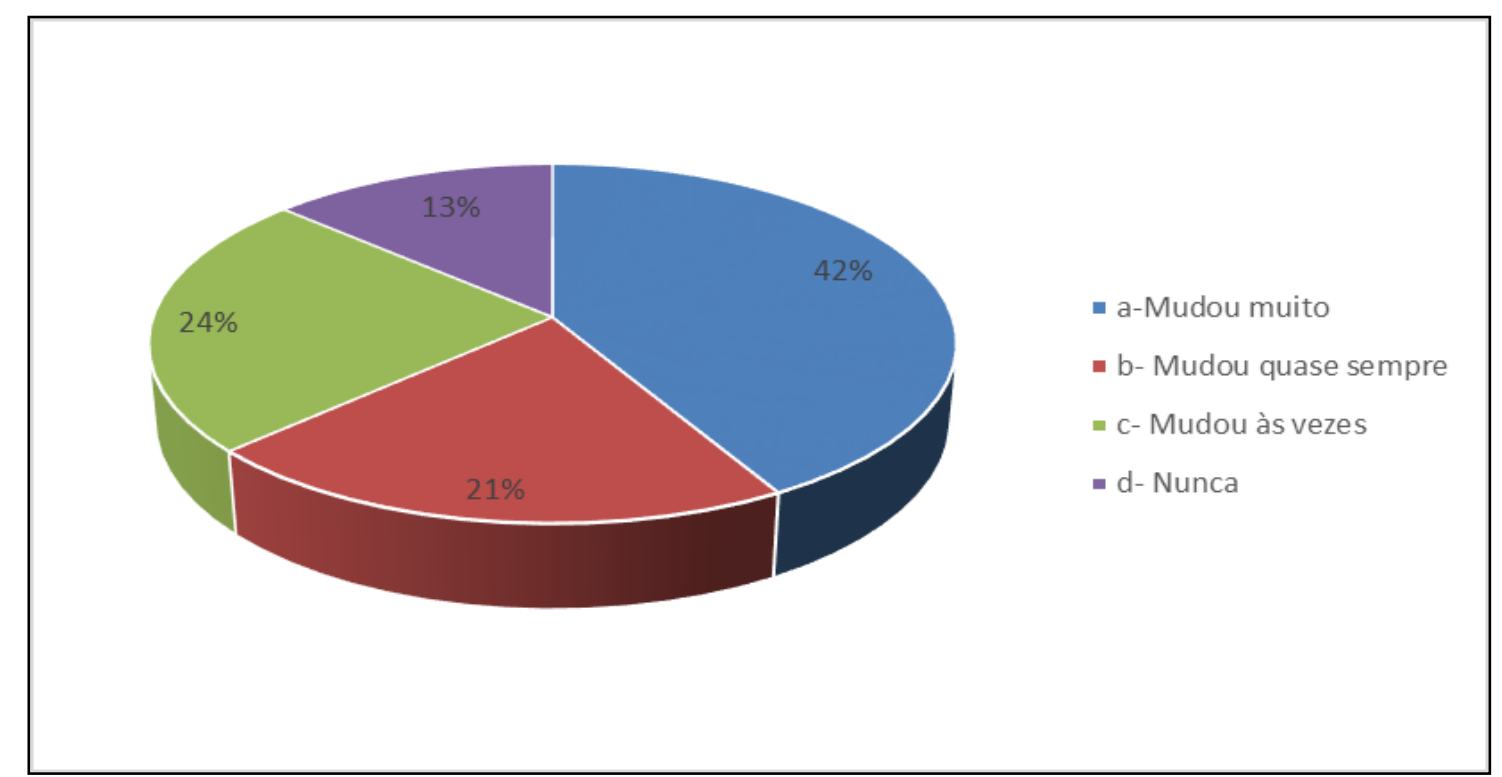

Fonte: dados da pesquisa.

Logo a seguir passamos a analisar os resultados do questionário fechado aplicados aos professores das escolas: Escolas Municipais Lafayete Cavalcante e Manoel da Costa Cirne, situadas no município de Campina Grande, Paraíba, Brasil. 
7.3. Analises dos resultados do questionário aplicado aos professores

O questionário fechado aplicado aos professores respondem ao objetivo específicos 1 e 2 da pesquisa: 1) Estimar a diferença no rendimento acadêmico dos alunos que têm acesso às TIC aos que não têm acesso; 2) Verificar se indices de aprovação e reprovação pode ser influenciado pelo uso das TIC nas escolas.

Gráfico 11: Você tem conhecimento da potencialidade do uso das TIC no ensino dos conteúdos de matemática?

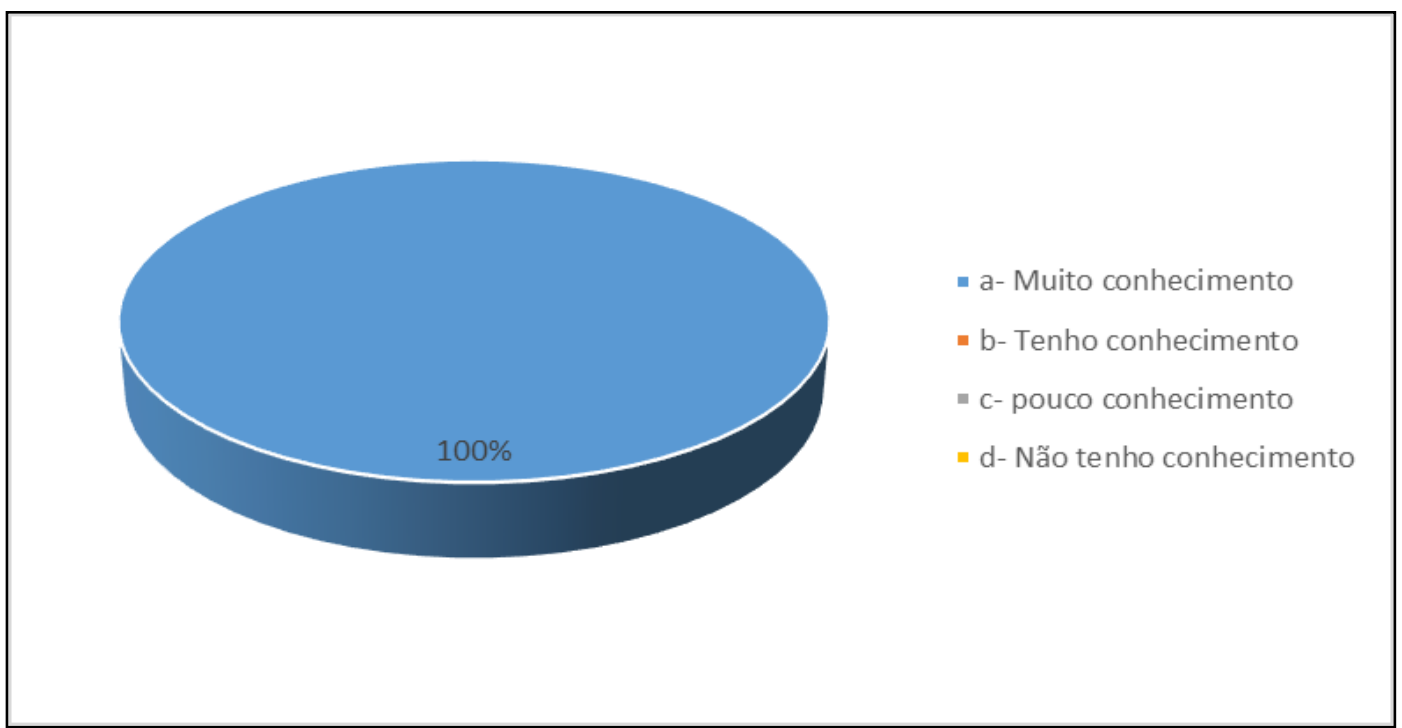

Fonte: dados da pesquisa.

Passando a analisar a primeira pergunta do questionário aplicado aos professores temos que: $100 \%$ dos professores responderam que tem muito conhecimento da potencialidade do uso das TIC no ensino dos conteúdos de matemática. Então, como respondem os professores que tem conhecimento da potencialidade do uso das TIC para o ensino dos conteúdos, os professores deveriam aliar esta potencialidade das TIC com a sua prática pedagógica dando novos impulsos ao ensino-aprendizado.

Segundo Siemens (2004) o cognitivismo frequentemente toma um modelo computacional de processamento da informação. A aprendizagem é vista como um 
processo de entradas, administradas na memoria de curto prazo, e codificadas para sua recuperação em longo prazo.

Gráfico 12: As TIC possibilita potencialidade a pratica pedagógica no ensino-aprendizado de matemática favorecendo o rendimento acadêmico dos seus alunos?

Fonte: dados da pesquisa.

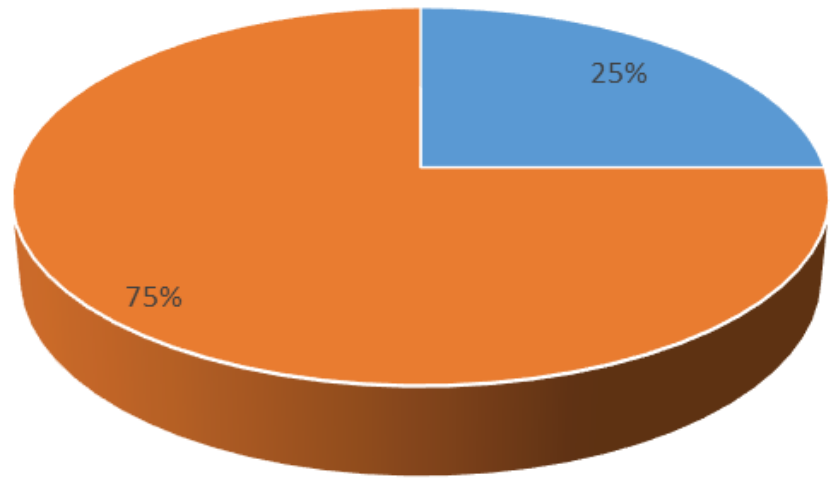

- a- Possibilita muito

- b- Possibilita

= C- Possibilita pouco

" d- Não possibilita

Analisando as respostas da segunda pergunta do questionário aplicado aos professores temos que: $75 \%$ dos professores responderam que possibilita as TIC potencialidade à pratica pedagógica no ensino-aprendizado de matemática favorecendo o rendimento acadêmico dos seus alunos e, somente $25 \%$ dos professores responderam que possibilita muito potencialidade à pratica pedagógica no ensino-aprendizado de matemática favorecendo o rendimento acadêmico dos seus alunos. Como percebemos nas respostas dos professores as TIC possibilita potencialidade a pratica pedagógica. Com a inserção das TIC na educação o contexto ensino-aprendizado mudou para melhor. Tanto os professores como os alunos foram beneficiados com novos recursos que favorecem a busca de conhecimentos imediatos e potencialidade em seus estudos e trabalhos.

Passando a analisar a terceira pergunta do questionário, gráfico 13, aplicado aos professores temos que: $50 \%$ dos professores responderam que têm usado muito os recursos tecnológicos como apoio ao ensino-aprendizado nas aulas de matemática e, 25\% dos professores responderam que têm usados os recursos tecnológicos como apoio ao ensino- 
aprendizado nas aulas de matemática. Como podemos ver muitos professores usam pouco os recursos tecnológicos em suas aulas, os professores de matemática tem que serem motivados a usarem as TIC em suas aulas, a coordenação das escolas investigadas tem que conscientizar estes professores do valor das TIC para a potencialidade da pratica pedagógica em sala de aula.

Gráfico 13: Tem usado os recursos tecnológicos como apoio ao ensino-aprendizado nas aulas de matemática?

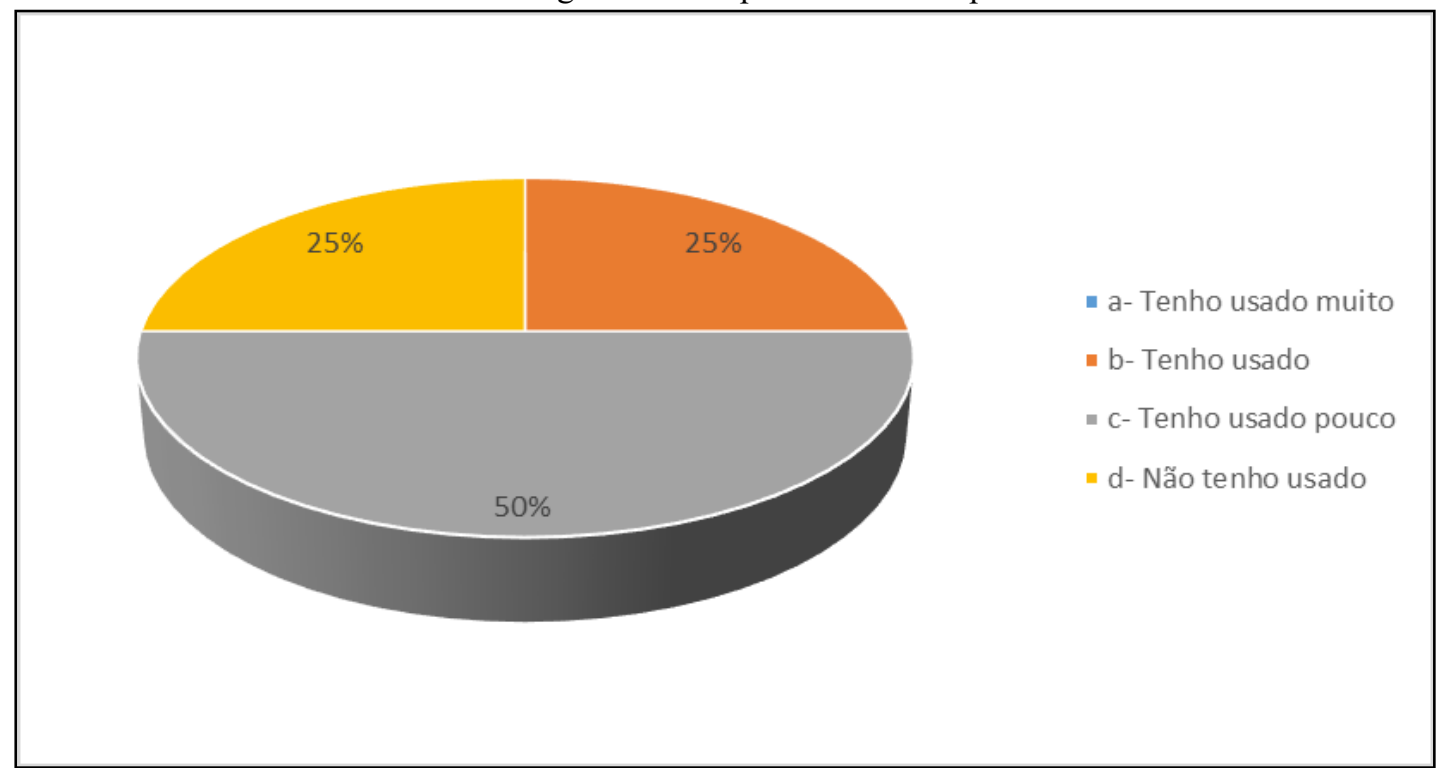

Fonte: dados da pesquisa.

Analisando a quarta pergunta do questionário, gráfico 14, aplicado aos professores, temos que: $75 \%$ dos professores responderam que quase sempre melhora $o$ rendimento acadêmico dos seus alunos quando usa as TIC como apoio ao ensinoaprendizado dos conteúdos de matemática em sala de aula e, somente $25 \%$ dos professores responderam que às vezes notam um melhor rendimento acadêmico dos seus alunos quando usa as TIC como apoio ao ensino-aprendizado dos conteúdos de matemática em sala de aula. 
Gráfico 14: Tem notado a diferença no rendimento acadêmico dos seus alunos quando usa as TIC como apoio ao ensino-aprendizado dos conteúdos de matemática em sala de aula?

Fonte: dados da pesquisa.

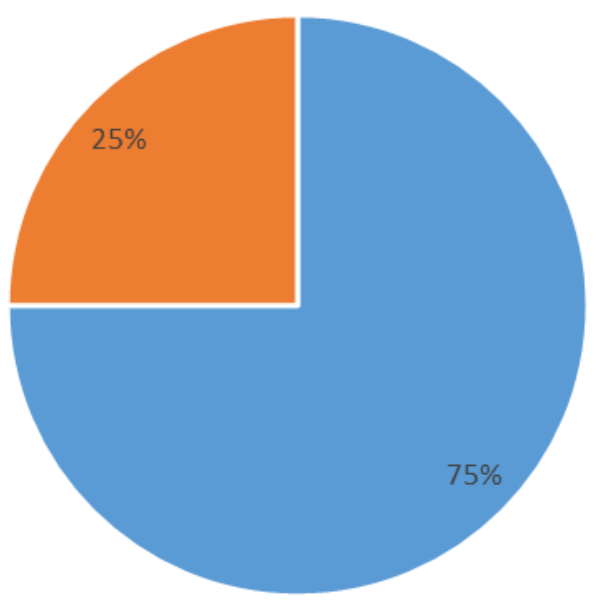

- b- Quase sempre melhora o rendimento

- c- Às vezes noto um melhor rendimento

- d- Nunca noto diferença no rendimento

Como já vimos na questão anterior que poucos professores usam os recursos tecnológicos em sala de aula, os resultados desta questão é uma consequência da questão anterior. Para que o rendimento de aprendizado aumente em sala de aula os professores tem que se atualizar e passar a usar as TIC em sala de aula, mas para isso os professores precisam se capacitar, ter cursos de formação continuada relacionados ao uso das TIC em sala de aula.

Analisando a quinta pergunta, gráfico 15, do questionário aplicado aos professores temos que: $50 \%$ dos professores responderam que a escola em que trabalha tem disponibilizado muito de laboratório de informática para você com seus alunos realizarem atividades usando os recursos tecnológicos e, 50\% dos professores responderam que a escola em que trabalha não tem disponibilizado de laboratório de informática para você com seus alunos realizarem atividades usando os recursos tecnológicos.

Uma questão muito critica na Educação brasileira, em pleno século XXI ainda encontramos escolas em cidades destacadas como Campina Grande sem laboratórios de informática. Infelizmente está é uma questão que envolve a gestão escolar e politica do município. 
Gráfico 15: A escola em que trabalha tem disponibilizado de laboratório de informática para você com seus alunos realizarem atividades usando os recursos tecnológicos?

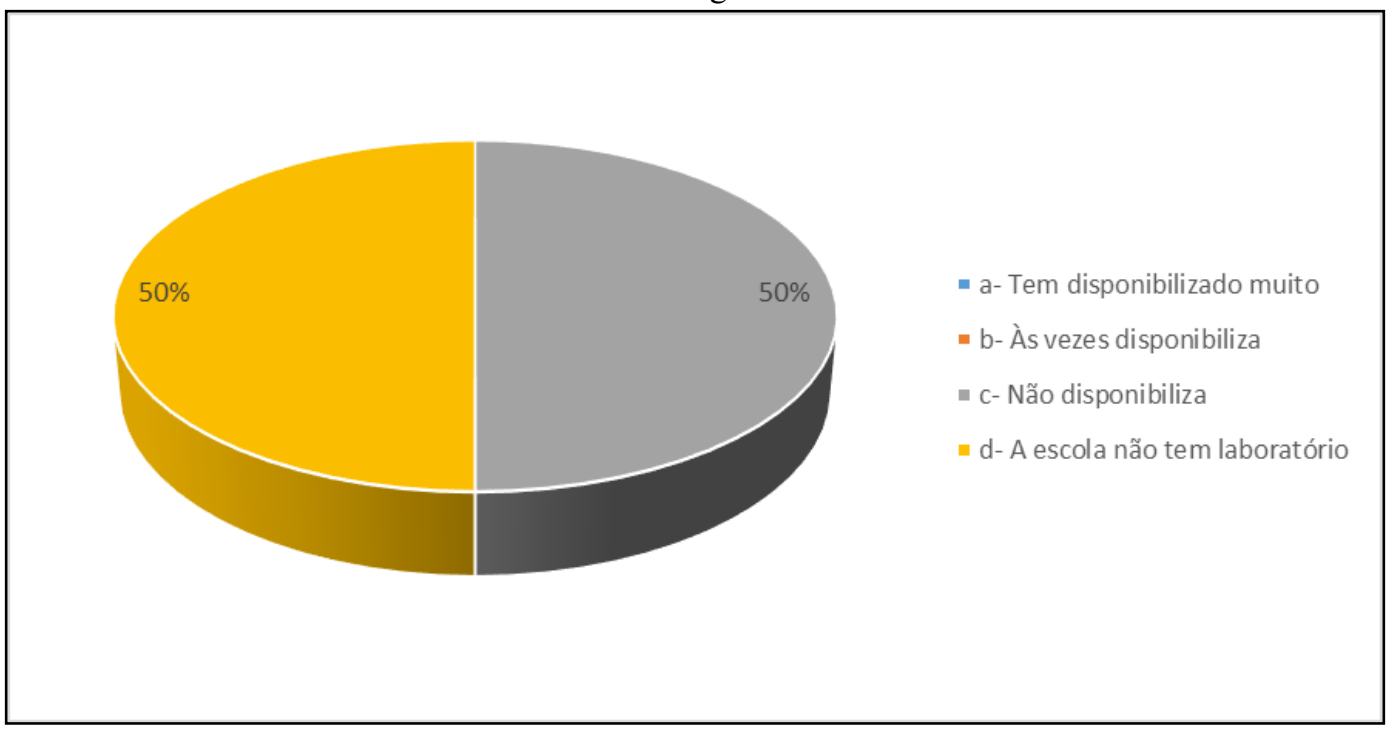

Fonte: dados da pesquisa.

Gráfico 16: O uso de aplicativos como jogos virtuais interativos como: Desafio Matemático, Matemática para Crianças, Perguntas de Matemática, Caça Palavras Matemática etc. Nas aulas de matemática motivam os alunos a socializar conhecimentos entre si durante as aulas?

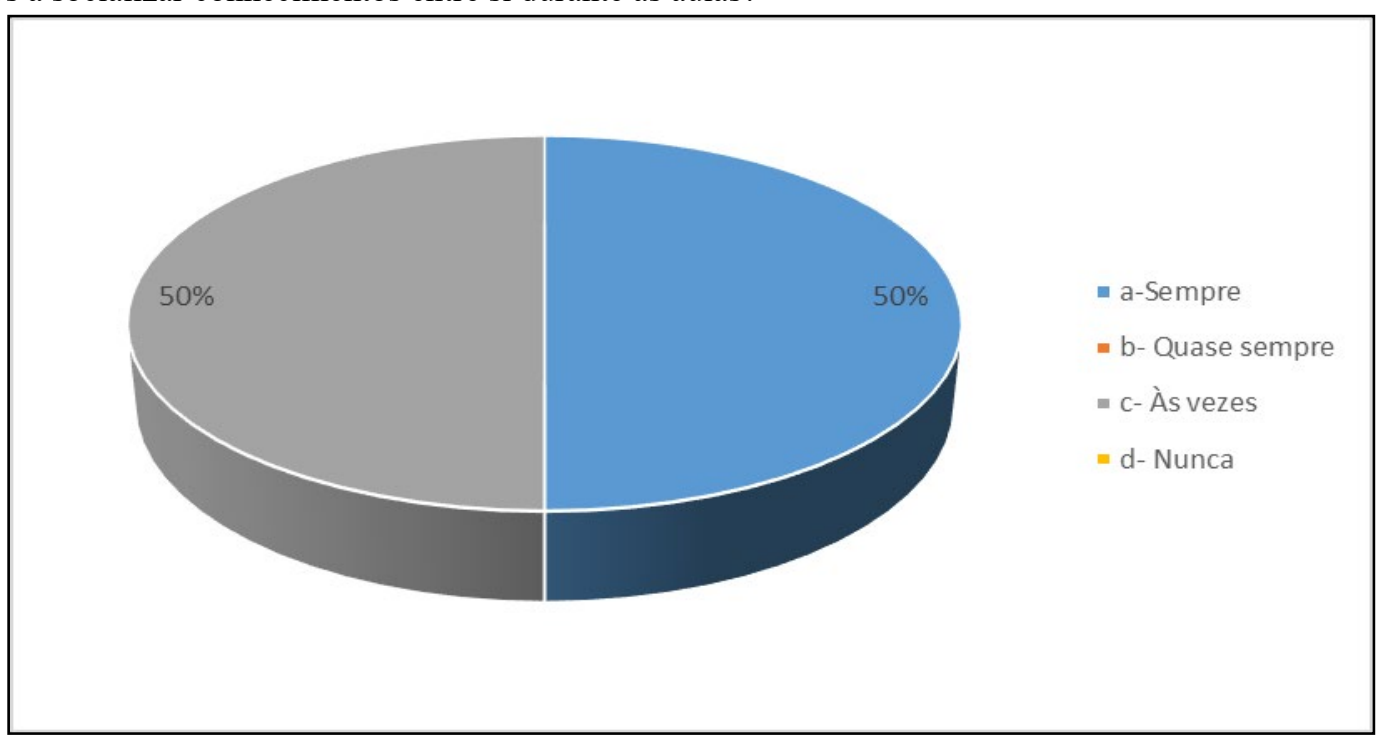

Fonte: dados da pesquisa.

Passando a analisar a sexta pergunta, gráfico 16, do questionário aplicado aos professores temos que: $50 \%$ dos professores responderam que sempre o uso de aplicativos como jogos virtuais interativos como: caça palavras, palavra cruzada, forca etc. Nas 
aulas de matemática motivam os alunos a socializar conhecimentos entre si durante as aulas e, os outros 50\% dos professores responderam que às vezes o uso de aplicativos como jogos virtuais interativos como: caça palavras, palavra cruzada, forca etc. Nas aulas de matemática motivam os alunos a socializar conhecimentos entre si durante as aulas. Como podemos ver os professores usam aplicativos em sala de aula juntamente com seus alunos motivando os alunos a socializar conhecimentos entre si durante as aulas.

Gráfico 17: Com o uso das TIC reforçando o aprendizado de matemática. Seus alunos tem melhorado o índice de aprovação na disciplina?

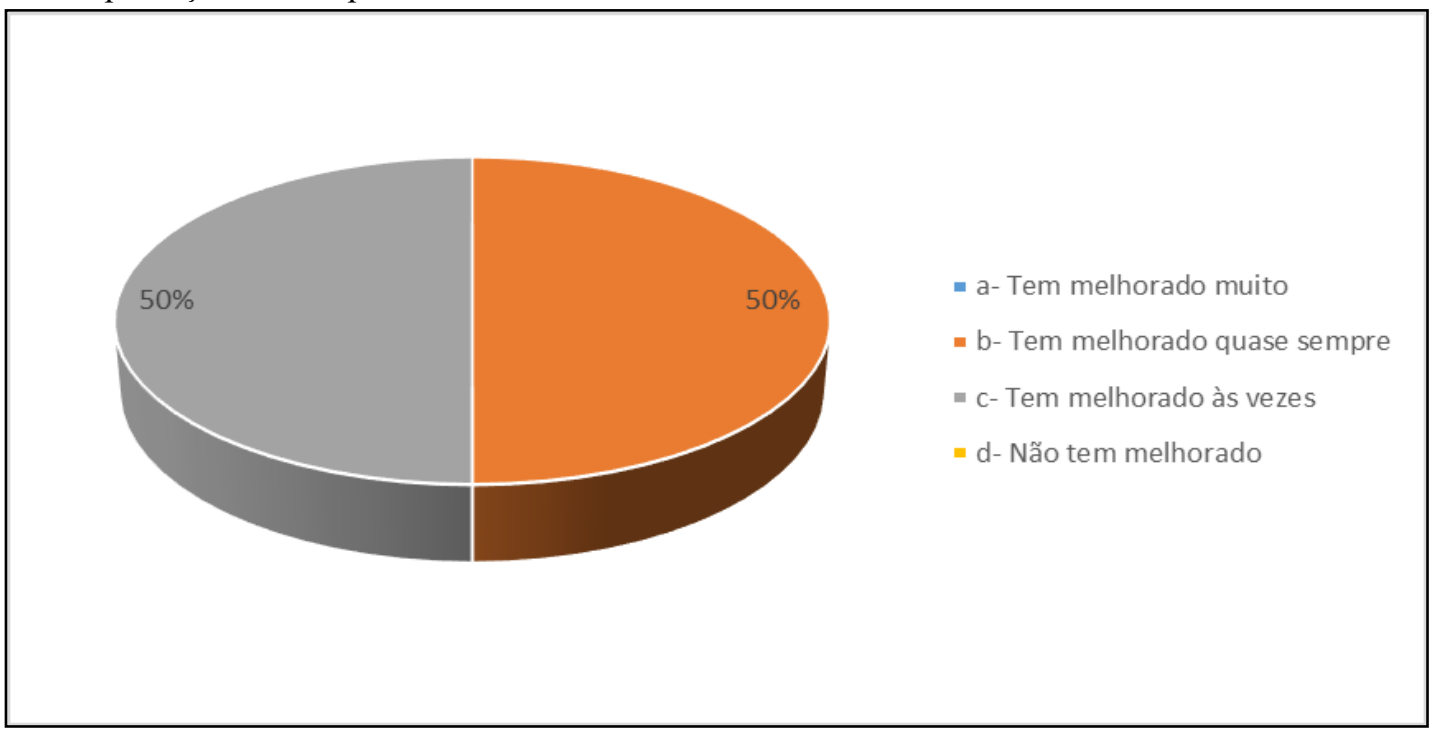

Fonte: dados da pesquisa.

Passando a analisar a sétima pergunta do questionário aplicado aos professores temos que: $50 \%$ dos professores responderam que o uso das TIC tem melhorado quase sempre o aprendizado de matemática. Seus alunos tem melhorado o índice de aprovação na disciplina e, os outros $50 \%$ dos professores responderam que com o uso das TIC tem melhorado às vezes o aprendizado de matemática. Seus alunos tem melhorado o índice de aprovação na disciplina.

Para Siemens (2004) muitos alunos se desempenaram numa variedade de áreas diferentes, e possivelmente sem relação entre si, ao longo de suas vidas. O aprendizado informal é um aspecto significativo de nossa experiência de aprendizagem. A educação formal já não constitui a maior parte de nossa aprendizagem. A aprendizagem acontece 
agora numa variedade de formas, através de comunidades de prática, redes pessoais, e através da realização de tarefas laborais.

Gráfico 18: O uso das TIC tem dado mais dinamicidade as suas aulas tem levado os alunos a se interessarem mais pelo aprendizado dos conteúdos de matemática? .

Fonte: dados da pesquisa.

Analisando a oitava pergunta do questionário aplicado aos professores temos que: $100 \%$ dos professores responderam que o uso das TIC tem levado quase sempre dinamicidade as suas aulas tem levado os alunos a se interessarem mais pelo aprendizado dos conteúdos de matemática.

Acentua Alarcão (2011) que o grande desafio para os professores vai ser ajudar a desenvolver nos alunos, futuros cidadão, a capacidade de trabalho autônomo e colaborativo, más também o espirito crítico.

Com o auxilio das TIC no ensino-aprendizado os professores podem melhor sua pratica pedagógica em sala de aula, dando aos alunos novas propostas de aprendizagem e favorecendo o desempenho dos conhecimentos adquiridos em aula juntamente com seus companheiros. 
Gráfico 19: Você gostaria de ter mais capacitação relacionada ao uso das TIC para melhor desenvolver seu trabalho com os alunos em sala de aula?

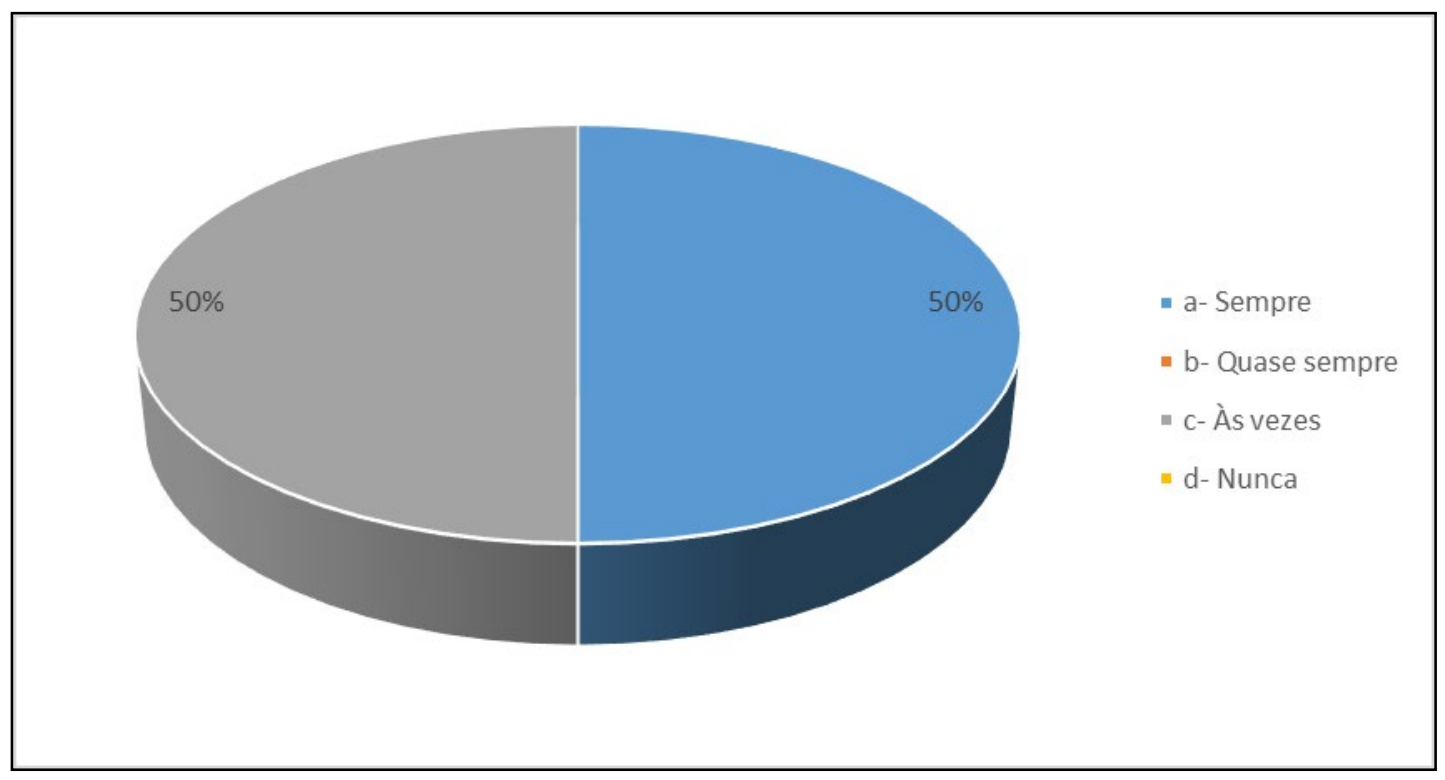

Fonte: dados da pesquisa.

Passando a analisar a nona pergunta do questionário aplicado aos professores temos que: $50 \%$ dos professores responderam que sempre gostaria de ter mais capacitação relacionada ao uso das TIC para melhor desenvolver seu trabalho com os alunos em sala de aula e, os outros 50\% dos professores responderam que às vezes gostaria de ter mais capacitação relacionado ao uso das TIC para melhor desenvolver seu trabalho com os alunos em sala de aula.

Uma das questões mais discutida, hoje, dentro do contexto educacional é como levar o aluno a desenvolver as competências interacionais e sociais. Dentro da modalidade do ensino-aprendizado de matemática, buscamos levar os nossos alunos a desenvolver estas competências por meios dos temas trabalhados em sala de aula não somente com atividades relacionadas a soma, adição, subtração ou multiplicação e sim a usar o raciocínio lógico a resolver problemas mais complexos.

Como ressalta ScienceWeek (2004) o caos é uma nova realidade para os trabalhadores do conhecimento. Para Siemens (2004) o caos é uma forma crítica de ordem. O caos é a interrupção da possibilidade de predizer, evidenciada em configurações 
complexas que inicialmente desafiam a ordem. A diferencia do construtivismo, o qual estabelece que os aprendizes tratam de desenvolver compreensão através de tarefas que geram significado, o caos sinala que o significado existe, e que o objetivo do aprendiz é reconhecer os patrões que parecem estar escondidos. A construção do significado e a formação de conexões entre comunidades especializadas são atividades importantes. 


\subsection{Discussão dos resultados da pesquisa}

Passando a discutir os resultados da pesquisa fazendo uma comparação com as respostas dadas pelos alunos e professores participantes através dos questionários. $\mathrm{Na}$ primeira discussão relacionada entre as respostas comparando-as, respostas dos alunos e professores, fazendo assim uma interrelação entre as respostas dos sujeitos da pesquisa. Considerando os objetivos específicos da pesquisa o questionário fechado aplicados aos professores respondem aos objetivos específicos 1 e 2 da pesquisa: 1) Estimar a diferença no rendimento acadêmico dos alunos que têm acesso às TIC aos que não têm acesso; 2) Verificar se índices de aprovação e reprovação pode ser influenciado pelo uso das TIC nas escolas; e o questionário fechado aplicado aos alunos responderam o terceiro objetivos especifico da pesquisa que é estabelecer se os alunos se sentiram mais estimulados a estudar matemática utilizando as TIC. Resultados do questionário aplicado aos alunos das escolas: Escolas Municipais Lafayete Cavalcante e Manoel da Costa Cirne, situadas no município de Campina Grande, Paraíba, Brasil.

Então, passando a discussão e a comparar o analises das respostas dadas pelos alunos e professores temos que:

A primeira pergunta do questionário - Como você se sente quando o professor usa as TIC nas aulas de matemática? -. Está relacionada a sexta pergunta do questionário aplicado aos professores - Está relacionada à quarta pergunta do questionário aplicado aos professores - Tem notado a diferença no rendimento acadêmico dos seus alunos quando usa as TIC como apoio ao ensino-aprendizado dos conteúdos de matemática em sala de aula? -. Os alunos responderam que se sentem muito incentivados a estudar quando os professores usam as TIC em sala de aula. Vejamos a resposta dos professores que sempre o uso de aplicativos como jogos virtuais interativos como: caça palavras, palavra cruzada, forca etc. Nas aulas de matemática motivam os alunos a socializar conhecimentos entre si durante as aulas.

Um dos valores do uso das TIC em sala de aula é que as TIC tem esse poder de motivar os alunos interagir entre si, em trocar conhecimentos por meio do uso dos aplicativos que possibilitam o aprendizado dinâmico de atividades especificas. Os alunos, 
nativos digitais, se sentem mais motivados a estudar com o uso dos recursos tecnológicos em sala de aula. Os recursos tecnológicos tem tomado um grau de importância maior do que certas atividades dadas nos livros didáticos. Sabemos que o livro didático tem deixado muito a desejar na elaboração de seus conteúdos e atividades.

A segunda pergunta do questionário - Como você ver as aulas de matemática quando o professor usa os recursos tecnológicos para ensinar os conteúdos?- se relaciona com a primeira pergunta do questionário aplicado aos professores- Você tem conhecimento da potencialidade do uso das TIC no ensino dos conteúdos de matemática?-. Observamos as respostas dos alunos que responderam que as aulas de matemática ficam muito mais atrativas com o uso dos recursos tecnológicos. Agora passamos a observar a resposta dos professores que responderam que tem muito conhecimento da potencialidade do uso das TIC no ensino dos conteúdos de matemática.

O processo de entrada do uso das TIC na Educação, na região nordeste do Brasil, ainda deixa muito a desejar, é muito lento, pois muitas escolas e professores não recebem suporte suficiente para trabalhar com as TIC em sala de aula, temos escolas com situações pregarias que muita das vezes não tem nem energia quando mais a disponibilidade de internet para que os professores possam trabalhar com seus alunos na escola.

A terceira pergunta do questionário - O professor tem usado muito as TIC para ensinar os conteúdos em sala de aula? -. Está relacionada à sexta pergunta do questionário aplicado aos professores - $O$ uso de aplicativos como jogos virtuais interativos como: Desafio Matemático, Matemática para Crianças, Perguntas de Matemática, Caça Palavras Matemática etc. Nas aulas de matemática motivam os alunos a socializar conhecimentos entre si durante as aulas? -. Os alunos responderam que os professores têm usados às vezes as TIC para ensinar os conteúdos em sala de aulas de matemática. Vejamos, os professores responderam que sempre o uso de aplicativos como jogos virtuais interativos como: caça palavras, palavra cruzada, forca etc. Nas aulas de matemática motivam os alunos a socializar conhecimentos entre si durante as aulas.

Sobre a quarta pergunta do questionário - As aulas de matemática se tornaram mais interessantes com o uso dos recursos tecnológicos pelos seus professores? -. Se relaciona a segunda pergunta do questionário fechado aplicado aos professores - As TIC 
possibilita potencialidade a pratica pedagógica no ensino-aprendizado de matemática favorecendo o rendimento acadêmico dos seus alunos? -. Os alunos responderam que sempre as aulas de matemática se tornaram mais interessantes com o uso dos recursos tecnológicos pelo seus professor. Observamos a resposta dada pelos professores que as TIC possibilita potencialidade à pratica pedagógica no ensino-aprendizado de matemática favorecendo o rendimento acadêmico dos seus alunos.

A quinta pergunta do questionário - As atividades de matemática ministradas por meios dos Recursos Tecnológicos têm melhorado seu desempenho no aprendizado dos conteúdos? -. Estar relacionada à terceira pergunta do questionário aplicado aos professores - Tem usado os recursos tecnológicos como apoio ao ensino-aprendizado nas aulas de matemática?-. Observamos que os alunos responderam que sempre as atividades de matemática ministradas por meios dos Recursos Tecnológicos têm melhorado seu desempenho no aprendizado dos conteúdos. Os professores responderam que têm usado muito os recursos tecnológicos como apoio ao ensino-aprendizado nas aulas de matemática.

A sexta pergunta do questionário - Você se sente mais estimulado com o uso dos recursos tecnológicos no auxílio das atividades de matemática? -. Está relacionada à oitava pergunta do questionário aplicado aos professores - O uso das TIC tem dado mais dinamicidade as suas aulas tem levado os alunos a se interessarem mais pelo aprendizado dos conteúdos de matemática? -. Vejamos a resposta dos alunos que responderam que sempre se sentem mais estimulados com o uso dos recursos tecnológicos no auxílio das atividades de matemática. E os professores responderam que o uso das TIC tem levado quase sempre dinamicidade as suas aulas tem levado os alunos a se interessarem mais pelo aprendizado dos conteúdos de matemática.

A sétima pergunta do questionário - Com a inclusão do uso da TIC nas aulas de matemáticas você tem percebido avanço no aprendizado? -. Esta pergunta se relaciona a quarta pergunta do questionário aplicado aos professores - Tem notado a diferença no rendimento acadêmico dos seus alunos quando usa as TIC como apoio ao ensinoaprendizado dos conteúdos de matemática em sala de aula?-. Observamos o que os alunos responderam que sempre têm percebido a inclusão do uso da TIC nas aulas de 
matemáticas avanço no aprendizado. Os professores responderam que quase sempre melhora o rendimento acadêmico dos seus alunos quando usa as TIC como apoio ao ensino-aprendizado dos conteúdos de matemática em sala de aula.

A oitava pergunta do questionário - As aulas de matemática ficaram mais atraentes com o uso dos recursos tecnológico pelo seu professor (a)? -. Está relacionada a sexta pergunta do questionário aplicado aos professores - $O$ uso de aplicativos como jogos virtuais interativos como: Desafio Matemático, Matemática para Crianças, Perguntas de Matemática, Caça Palavras Matemática etc. Nas aulas de matemática motivam os alunos a socializar conhecimentos entre si durante as aulas? -. Vejamos a resposta dos alunos Os alunos responderam que as aulas de matemática ficam muito mais atraentes de matemática com o uso dos recursos tecnológico pelo seu professor. Observamos a resposta dos professores sempre o uso de aplicativos como jogos virtuais interativos como: caça palavras, palavra cruzada, forca etc. Nas aulas de matemática motivam os alunos a socializar conhecimentos entre si durante as aulas.

Os recursos tecnológicos, os aplicativos educativos, com a sua expansão no dia-adia dos adolescentes tem ganhado uma grande influencia no ensino-aprendizado. Sua potencialidade e capacidade de interação que gera nos alunos tem levado os alunos e professores cada dia mais a usarem não somente em sala de aula como em suas vidas fora da sala de aula.

A nona pergunta do questionário - O professor sempre incentiva a classe usar mais as TIC para melhorar o aprendizado dos conteúdos de matemática? -. Está relacionada à quarta pergunta do questionário aplicado aos professores - Tem notado a diferença no rendimento acadêmico dos seus alunos quando usa as TIC como apoio ao ensino-aprendizado dos conteúdos de matemática em sala de aula? -. Vejamos a resposta dos alunos que responderam que os professores incentivam muito a usar mais as TIC para melhorar o aprendizado dos conteúdos de matemática. Vejamos a resposta dos professores que responderam que quase sempre melhora o rendimento acadêmico dos seus alunos quando usa as TIC como apoio ao ensino-aprendizado dos conteúdos de matemática em sala de aula 
A décima pergunta do questionário - $O$ uso das TIC tem mudado seu interesse pelo aprendizado da disciplina de matemática? -. Esta relacionada a quinta pergunta do questionário aplicado aos professores - A escola em que trabalha tem disponibilizado de laboratório de informática para você com seus alunos realizarem atividades usando os recursos tecnológicos? -. Observamos a resposta dos alunos responderam que o uso das TIC mudou muito o seu interesse pelo aprendizado da disciplina de matemática. Os professores responderam que a escola em que trabalha tem disponibilizado muito de laboratório de informática para você com seus alunos realizarem atividades usando os recursos tecnológicos.

Como podemos observar as respostas dos alunos e dos professores tem uma ligação direta, uma complementa a outra, isso é muito interessante pois prova que o objetivo do questionário foi alcançado para a formulação dos resultados e discussão necessárias para a referida pesquisa. A discussão aqui relatada pelo pesquisador é de suma importância para compactar os resultados da pesquisa. Através das relações realizadas entre cada pergunta dos dois questionários, questionários estes que foram elaborados com a finalidade de responder a determinados objetivos específicos, as perguntas dos questionários manter uma correlação dando mais profundidade ao tema investigado e, aos resultados com mais relevância para nosso estudo. 


\section{CONCLUSÃO}

Passando a conclusão da pesquisa intitulada Análise das contribuições das TIC à aprendizagem matemática dos alunos das escolas municipais de Campina Grande-PB. E com o objetivo geral determinar a forma como melhorou o desempenho dos alunos das Escolas Municipais Lafayete Cavalcante e Manoel da Costa Cirne que estudam matemática utilizando às TIC. E os objetivos específico que são: 1) Estimar a diferença no rendimento acadêmico dos alunos que têm acesso às TIC aos que não têm acesso; 2) Verificar se índices de aprovação e reprovação pode ser influenciado pelo uso das TE nas escolas; 3) Estabelecer se os alunos se sentiram mais estimulados a estudar matemática utilizando as TIC.

Passando a conclusão do primeiro objetivo especifico da pesquisa que é: 1) Estimar a diferença no rendimento acadêmico dos alunos que têm acesso às TIC aos que não têm acesso. Temos as seguintes respostas dadas com base nos resultados do questionário fechado aplicado aos professores: Os professores responderam que tem muito conhecimento da potencialidade do uso das TIC no ensino dos conteúdos de matemática. Então, como respondem os professores essa potencialidade favorece novos impulsos ao ensino-aprendizado de matemática; os professores responderam que as TIC possibilitam potencialidade à pratica pedagógica no ensino-aprendizado de matemática favorecendo o rendimento acadêmico dos seus alunos e, uma pequena parte dos professores responderam $(25 \%)$ que possibilita muito potencialidade à pratica pedagógica no ensino-aprendizado de matemática favorecendo o rendimento acadêmico dos seus alunos. Como percebemos nas respostas dos professores as TIC possibilita potencialidade a pratica pedagógica. Com a inserção das TIC na educação o contexto ensino-aprendizado melhorou muito. E ainda tanto os professores como os alunos foram beneficiados com novos recursos que favorecem a busca de conhecimentos imediatos e potencialidade em seus estudos (alunos) e trabalhos (professores); os professores (50\%) responderam que têm usado muito os recursos tecnológicos como apoio ao ensino-aprendizado nas aulas de matemática. Como podemos ver a quantidade de professores que usam os recursos tecnológicos em suas aulas 
não é o suficiente para qualificar o uso das TIC no ensino-aprendizado em sala de aula, os professores de matemática tem que serem motivados a usarem as TIC em suas aulas, a coordenação das escolas investigadas tem que conscientizar estes professores do valor das TIC para a potencialidade da pratica pedagógica em sala de aula; os professores responderam que quase sempre melhora o rendimento acadêmico dos seus alunos quando usa as TIC como apoio ao ensino-aprendizado dos conteúdos de matemática em sala de aula. Como já vimos na questão anterior que poucos professores usam os recursos tecnológicos em sala de aula, os resultados desta questão é uma consequência da questão anterior. Para que o rendimento de aprendizado aumente em sala de aula os professores têm que se atualizar e passar a usar as TIC em sala de aula, mas para isso os professores precisam se capacitar, ter cursos de formação continuada relacionados ao uso das TIC em sala de aula; ainda os professores responderam que a escola em que trabalha não tem disponibilizado de laboratório de informática para você com seus alunos realizarem atividades usando os recursos tecnológicos. Uma questão muito critica na Educação brasileira, em pleno século XXI ainda encontramos escolas em cidades destacadas como Campina Grande sem laboratórios de informática. Infelizmente está é uma questão que envolve a gestão escolar e politica dos municípios brasileiros.

A conclusão do segundo objetivo especifico da pesquisa: 2) Verificar se índices de aprovação e reprovação pode ser influenciado pelo uso das TE nas escolas. Por meio do questionário aplicado aos professores. Temos as seguintes conclusões: os professores responderam que sempre o uso de aplicativos como jogos virtuais interativos. Nas aulas de matemática os aplicativos motivam os alunos a socializar conhecimentos entre si durante as aulas. Como podemos ver os professores usam aplicativos em sala de aula juntamente com seus alunos motivando os alunos a socializar conhecimentos entre si durante as aulas; ainda os professores responderam que o uso das TIC tem melhorado quase sempre o aprendizado de matemática. Seus alunos tem melhorado o índice de aprovação na disciplina; os professores responderam também que o uso das TIC tem levado quase sempre dinamicidade as suas aulas tem levado os alunos a se interessarem mais pelo aprendizado dos conteúdos de matemática.

Encerrando a conclusão do segundo objetivo especifico da pesquisa se concluir que as TIC favorecem o índice de aprovação e reprovação pode ser influenciada pelo uso 
das TIC nas escolas. Pois quando os recursos tecnológicos forem bem associados a pratica pedagógica, e os professores forem conscientizados dos benefícios que o uso das TIC favorece ao desenvolvimento do ensino-aprendizado o índice de aprovação dos alunos na disciplina matemática.

A conclusão do terceiro objetivo especifico da pesquisa que é: Estabelecer se os alunos se sentiram mais estimulados a estudar matemática utilizando as TIC. Com base no questionário aplicado aos alunos. Temos que: os alunos entrevistados responderam que se sentem muito incentivados a estudar. Como podemos observar as respostas acima se conclui que as TIC incentivam muito os alunos a estudarem os conteúdos de matemática; continuando os alunos responderam que as aulas de matemática ficam muito mais atrativas com o uso dos recursos tecnológicos. Aqui vemos que os recursos tecnológicos usados pelos professores têm grande respaldo nas aulas de matemática, os mesmos, favorecem mais atração às atividades aplicadas aos alunos. Hoje tudo aquilo que se pode usar para favorecer o desenvolvimento da pratica pedagógica é de grande importância para o crescimento do aprendizado dos alunos e também para o trabalho do professor em sala de aula; os alunos $(33 \%)$ responderam que sempre as aulas de matemática se tornaram mais interessantes com o uso dos recursos tecnológicos por seus professores; uma quantidade não suficiente de alunos entrevistados responderam que sempre as atividades de matemática ministradas por meios dos Recursos Tecnológicos têm melhorado seu desempenho no aprendizado dos conteúdos. Como podemos perceber as atividades de matemáticas ministradas por meio de recursos tecnológicos ganham potencialidade, os alunos passam a aprender mais, o professor obtém êxito na aplicação das atividades; $43 \%$ responderam que sempre sentem-se mais estimulados com o uso dos recursos tecnológicos no auxílio das atividades de matemática. Sobre a referido objetivo é importante ressaltar que o professor tem que se empenhar a trabalhar mais com os recursos tecnológicos e demonstrar para os alunos o valor da utilização dos mesmos para o melhor aprendizado dos conteúdos ministrados; os alunos entrevistados responderam que sempre têm percebido a inclusão do uso da TIC nas aulas de matemáticas avanço no aprendizado; os alunos entrevistados responderam que muito mais atraente ficam as aluas de matemática com o uso dos recursos tecnológico pelo seu professor. Como podemos ver a maioria dos alunos confirmam que as aulas de matemática ficam mais atraentes quando o professor usa os 
recursos tecnológicos; os alunos responderam que os professores incentivam muito a usar mais as TIC para melhorar o aprendizado dos conteúdos de matemática.

Finalizando a conclusão do terceiro objetivo especifico da pesquisa podemos concluir que uma boa parte dos alunos (50\%) se sentiram mais estimulados a estudar matemática utilizando as TIC. Com base no questionário aplicado aos alunos. Então, como já foi citado anteriormente, nem todos os professores aderiram ao uso das TIC associados a sua pratica pedagógica, muitos ainda não tem o conhecimento necessário para trabalhar com os recursos tecnológicos em sala de aula, poucos fazem uso dos aplicativos educativos que por sua vez estimulam os alunos na realização de atividades de vários níveis de conhecimento dentro do ensino da matemática.

Para finalizar as conclusões desta pesquisa respondendo ao objetivo geral da mesma temos: o desempenho dos alunos nas aulas de matemática tem melhorado com o auxilio do uso das TIC (recursos tecnológicos e aplicativos educativos), mas os professores precisam de influencia para usarem os recursos tecnológicos associando as suas atividades em sala de aula, buscando assim fazer uma ponte entre a realidade dos alunos e os recursos que são oferecidos hoje aos mesmos. Tudo isso também irá depender do apoio da Coordenação e Direção das Escolas em que a pesquisa foi aplicada: Escolas Municipais Lafayete Cavalcante e Manoel da Costa Cirne.

Para que o ensino-aprendizado tenha sucesso ele não depende somente da qualidade e formação profissional dos professores. Ela depende muito mais do apoio dos entes envolvidos no processo educacional, para que tudo saia a contento, todos os sujeitos da educação têm que fazer bem a sua parte. 


\section{RECOMENDAÇÕES}

Depois dos resultados da pesquisa obtidos pelos instrumentos aplicados aos alunos e professores das escolas: Escolas Municipais Lafayete Cavalcante e Manoel da Costa Cirne. Chegamos ao entendimento que as escolas precisam das seguintes recomendações para melhorar o desempenho dos alunos na disciplina de matemática com o auxilio das TIC e os recursos tecnológicos.

Seguem algumas recomendações para os Diretores e Coordenadores das Escolas pesquisadas, as mesmas, darão um novo contexto no ensino-aprendizado da disciplina de matemática:

- Habilitar o Laboratório de Informática, dando aos professores melhores condições de trabalho junto com seus alunos, somente assim os professores poderão trabalhar com as TIC, oportunizar novos ambiente de estudos para seus alunos;

- Investir em formação continuada, como o uso das TIC na Educação, para todos os docentes;

- Promover Semana de Tecnologias e Informação, levando os alunos e professores a apresentarem projetos educativos e dando oportunidades aos alunos a demonstrarem o que aprenderam para toda a comunidade escolar;

- Incentivar os professores a participarem ativamente de Congressos, Seminários, Encontros e Colóquios Nacionais e Internacionais, promovendo o desenvolvimento dos alunos;

- Os coordenadores pedagógicos junto com os professores analisar aplicativos educativos para inseri-los no planejamento da disciplina de matemática etc; 
- Levar os alunos a comunidade para demonstrar o que aprende na escola, compartindo assim com alunos de outros níveis seu aprendizado mediado pelas TIC;

Estas recomendações são essenciais para potencializar o ensino-aprendizado de matemática e suas tecnologias e diminuir o índice de reprovação dos alunos na disciplina. Quando os sujeitos envolvidos na Educação dos jovens aceitarem a conscientização da modernidade, do novo, das mudanças que o mundo em vários ambientes passou. Com certeza a escola, os docentes, os alunos passaram a contemplarem o sucesso sem muitas dificuldades.

Almejamos que com esta pesquisa, a parti da apresentação de seus resultados, não só o contexto educacional das escolas pesquisadas como de nosso Brasil tenham um novo enfoque baseado no ensino-aprendizado de matemática pelos alunos do Ensino Fundamental Maior. Esperamos que novos estudos sobre o uso das TIC sejam realizados para potencializar a Educação brasileira, levando os professores a se capacitar com o uso das TIC para levar a seus alunos novas metodologias de aprendizado valorizando todos os recursos que a evolução tecnológica dispõe a sociedade. 


\section{REFERENCIAS}

Alegre, Laíze M. P. (2005). Utilização das Tecnologias da Informação e da Comunicação, naprática docente, numa Instituição de Ensino tecnológico. Tese de Doutorado, Campinas, UNICAMP.

Amaral, L. H.; Barroqueiro, C. H.; Marques, W. B.; Shitsuka, D. M. (2014). O Uso das Tecnologias da Informação e da Comunicação no Ensino de Ciências e Matemática. http://www.pucrs.br/ciencias/viali/tic_literatura/artigos/tics/ano-1-no1-p-75.pdf. Acessado em 12/03/2018.

Assmann, H. (2005). Redes digitais e metamorfose do aprender. Petrópolis, RJ: Vozes.

Assmann, H. (2000). A metamorfose do aprender na sociedade da informação. http://www.scielo.br/pdf/ci/v29n2/a02v29n2. Acessado em 10/11/2016.

Barreto, R. G. (2009). As Tecnologias na Política Nacional de Formação de Professores a Distância: Entre a Expansão e a Redução. Educ. Soc., Campinas, vol. 29, n. 104 Especial,p. 919-937, out. 2008. http://www.scielo.br/pdf/es/v29n104/a1329104.pdf. Acessado em 02/03/2016.

BRASIL, MEC (1996). Ministério da Educação e da Cultura. Lei de Diretrizes e Bases da Educação Nacional (Lei n 9394/96), Senado federal, Brasília.

Brown, J. S. (2002). Growing Up Digital: How the Web Changes Work, Education, and the Ways People Learn. United States Distance Learning Association. Retrieved on $\begin{array}{llll}\text { December } & 10, & \text { 2004, }\end{array}$ http://www.usdla.org/html/journal/FEB02_Issue/article01.html. Acessado em $22 / 03 / 2017$.

Câmponez, L. G. B.; Ferreira, E. F. P.; \& Scortegagna, L. (2015). Integração das Tecnologias com o Ensino da Matemática: Transformações e Perspectivas no Processo de Ensino e Aprendizagem. 
http://www.ufjf.br/emem/files/2015/10/INTEGRA\%C3\%87\%C3\%83O-DAS. Acessado em 10/10/2016.

Castells, M. A. (2000). A era da informação: economia, sociedade e cultura. São Paulo: Ed. Paz e Terra.

Chaves, E. O. C. (2008). Tecnologia e educação: o futuro da escola na sociedade da informação. Campinas: Mindware Editora, 1998. CRUZ, José M. de O. Processo ensino-aprendizagem na sociedade da informação. Educação \& Sociedade, vol. 29. N. 105, Campinas, set./dez. 2008. DELAUNAY, Geneviève J. Novas tecnologias, novas competências. Educar em Revista, n. 31, Curitiba.

Citelli, A. O.; Costa, M. C. C. (2011). Educomunicação: construindo uma nova área de conhecimento. São Paulo: Paulinas, 2011.

D’ambrósio, U. (1996). Educação matemática: da teoria à prática. Campinas, SP: Papirus, 1996, p. 17-28. Coleção Perspectivas em Educação Matemática.

Demo, Pedro. (2004). Professor do Futuro e reconstrução do conhecimento. 2 ed. Petrópolis-RJ: Vozes.

Diehl, A. A. (2004). Pesquisa em ciências sociais aplicadas: métodos e técnicas. São Paulo: Prentice Hall.

Folha. (2012). Primeiro computador do mundo é religado em museu na Inglaterra. Revista - FOLHA DE SÃO PAULO. http://www1.folha.uol.com.br/tec/1188459-primeirocomputador-do-mundo-e-religado-em-museu-na-inglaterra.shtml. Acessado em $12 / 06 / 2017$.

Freire, P.I.M.; Freire, G.H. (1996). Pedagogia da Autonomia. São Paulo, Ed. Paz e Terra.

Guillemas, R. R. (2006). Las nuevas tecnologías aplicadas a la enseñanza de español como lengua extranjera. (Instituto Cervantes de Varsovia-Cracovia). Acessado em $23 / 04 / 2017$.

Kerlinger, F. N. (2002).Metodologia da pesquisa em ciências sociais: um tratado conceitual. São Paulo: EPU. 
Kleiner, A. (2002). Karen Stephenson's Quantum Theory of Trust. Retrieved December 10, 2004 from http://www.netform.com/html/s+b\%20article.pdf. Acessado em $22 / 03 / 2017$.

Lima, E. B. e Silva, M. G. G. (2012). Educação e professor diante do uso das novas tecnologias. Fórum Internacional d Pedagogia. Campina Grande, REALIZE Editora, http://editorarealize.com.br/revistas/fiped/trabalhos/98b297950041a42470269d562 60243a1.pdf. Acessado em 10/11/2016.

Machado, S. D. A. (2002). Engenharia Didática. In: MACHADO, Silvia Dias A. Educação Matemática: uma introdução. $2^{\mathrm{a}}$ ed. São Paulo: EDUC.

Marconi, M. A.; Lakatos, E. M. (2009). Fundamentos em metodologia científica. 6. ed. 7. Reimpr. São Paulo, Atlas.

Mason, Jennifer. (1996). Qualitative Researching. London: Sage.

Moreira, Marco Antônio. (2012). Teorias de aprendizagem. 2a . ed. São Paulo: E.P.U.

Oliveira, M. M. (2007). Como fazer pesquisa qualitativa. Petrópolis: Vozes.

Oliveira, J.F.; Santos, C.A. (2009). Políticas e gestão da educação básica no Brasil: limites e perspectivas. Educação \& Sociedade, Campinas, v. 28, n. 100, p. 921-946, 2009.

Perrenoud, P. et al. (2000). 10 novas competências para ensinar. Porto Alegre: Artes Médicas Sul.

Perius, A. A. B. (2012). A Tcnologia Aliadao ao Ensino de Matemática. Universidade Federal do Rio Grande do Sul. Especialização em Mídias na Educação. Cerro Largo,

RS. https://www.lume.ufrgs.br/bitstream/handle/10183/95906/000911644.pdf?sequence $=1$. Acessado em 19/10/2016.

Prensky, M. (2008). Digital Natives, Digital Immigrants. From On the Horizon, NCB University Press, Vol. 9, n. 5, October 2001. ROSA, Rosane R. da e VIALI, Lori 
Utilizando recursos computacionais (planilha) na compreensão dos Números Racionais. Revista Bolema, Vol. 31, ano 21, Rio Claro.

Richardson, R. J.(1999) PESQUISA Social|: Método e técnicos. 3 ed. São Paulo: Atlas.

Ribeiro, F. M. \& Paz, M. G. (2013). O ensino da matemática por meio de novas tecnologias.http://facos.edu.br/publicacoes/revistas/modelos/agosto_2013/pdf/o_en sino_da_matematica_por_meio_de_novas_tecnologias.pdf. Acessado em 10/10/2016.

Santos, M. A. (2016). Novas tecnologias no ensino de matemática: possibilidades e Desafios.

http://www.pucrs.br/famat/viali/tic_literatura/artigos/tics/101092011085446.pdf. Acessado em 15/09/2017.

Santos, I. G. D. \& Souza, J. R. (2009). EDUCAÇÃO MATEMÁTICA E MÍDIAS TECNOLÓGICAS: UMA POSSIBILIDADE PARA A AÇÃO EDUCATIVA? $\begin{array}{lllll}\text { Estudo da na } & 6^{\mathrm{a}} \text { serrie. }\end{array}$ http://www.diaadiaeducacao.pr.gov.br/portals/pde/arquivos/1955-8.pdf. Acessado em 10/11/2016.

Silva, F. A. (2015). Novas tecnologias: Contribuições no processo de ensino aprendizagem da matemática. Dissertação Acadêmica de Maestría em Ciências de la Educación. Universidad de la Integración de las Américas, Asuncíón, Paraguay.

Silva, I. S. (2013). O uso das TIC pelos professores e alunos Centro de Estudos Brasileiros (Asunción, Paraguay), dentro do contexto educativo e social como ferramentas complementares no processo ensino-aprendizagem de PLE. Ministério da Educação Universidade Federal dos Vales do Jequitinhonha e Mucuri - UFVJM Minas Gerais - Brasil Revista Vozes dos Vales: Publicações Acadêmicas Reg.: 120.2.095 - 2011 - UFVJM ISSN: 2238-6424 QUALIS/CAPES - LATINDEX Nº. 04 - Ano II - 10/2013 http://www.ufvjm.edu.br/vozes. Acessado em 10/10/2016.

Vaill, P. B., (1996). Learning as a Way of Being. San Francisco, CA, Jossey-Blass Inc. 
Xexéo, G. (2003). O nascimento da Internet. Ciência Hoje, Vol. 33, n. 194, p. 78-79. 


\section{APENDICES}

Apêndices 01: Solicitação de Aplicação da Pesquisa

\section{SOLICITAÇÃO APLICAÇÃO DA PESQUISA.}

Ilmo. Sr.

Venho por meio deste pedi-lhe autorização para a aplicação de minha pesquisa de doutorado juntamente com os professores e alunos do Ensino Fundamental Maior (do $6^{\circ}$ ao $9^{\circ}$ ano) desta instituição meus instrumentos de pesquisa a partir do corrente mês. Gostaria de aplicar grupos de horários e se possível com grupos das professoras que colaboraram com a entrevista que eu apliquei.

Com as professoras na semana passada sobre a aplicação de um questionário com os seus alunos e as mesmas concordaram.

Desde já agradeço a sua colaboração para com a minha pesquisa.

Att.

,03 de de 2018 .

Prof. Flaviano Aguiar Silva 
Apêndices 02: Declaração participação dos professores

\section{DECLARAÇÃO}

Eu Professor (a), , declaro para os

devidos fins que participei da pesquisa intitulada "ANÁLISE DAS CONTRIBUIÇÕES DAS TIC À APRENDIZAGEM MATEMÁTICA DOS ALUNOS DAS ESCOLAS MUNICIPAIS DE CAMPINA GRANDE-PB" como ator do processo de pesquisa, servindo de fonte de informação, de acordo com exigências institucionais, para o trabalho de investigação feito pelo aluno doutorando Flaviano Aguiar Silva, da Universidade Autônoma de Assunção, no período de 02/fevereiro a 30 de abril de 2018.

Por ser verdade firmo de próprio punho esta declaração.

de de 2018. 
Apêndices 03: Declaração participação dos alunos

UNIVERSIDAD AUTONOMA DE ASUNCION -UAA

FACULTAD CIENCIAS JURÍDICAS, POLITICAS Y DE LA COMUNICACIÓN

DOCTORADO EN CIENCIAS DE LA EDUCACION

\section{DECLARAÇÃO}

Eu Aluno (a), declaro para os devidos fins que participei da pesquisa intitulada "ANÁLISE DAS CONTRIBUIÇÕES DAS TIC À APRENDIZAGEM MATEMÁTICA DOS ALUNOS DAS ESCOLAS MUNICIPAIS DE CAMPINA GRANDE-PB" como ator do processo de pesquisa, servindo de fonte de informação, de acordo com exigências institucionais, para o trabalho de investigação feito pelo aluno doutorando Flaviano Aguiar Silva, da Universidade Autônoma de Assunção, no período de 02/fevereiro a 30 de abril de 2018.

Por ser verdade firmo de próprio punho esta declaração.

de de 2018. 
Apêndices 04: Questionário aplicado aos alunos

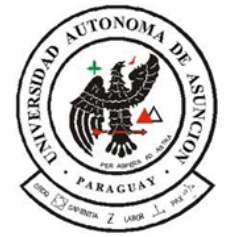

UNIVERSIDAD AUTONOMA DE ASUNCION - UAA

FACULTAD CIENCIAS JURÍDICAS, POLITICAS Y DE LA COMUNICACIÓN

DOCTORADO EN CIENCIAS DE LA EDUCACION

\section{FORMULÁRIO DE VALIDAÇÃO DE QUESTIONÁRIO PRÉ-TÉCNICA}

Prezado(a) Aluno (a) venho pedir a vossa participação na minha pesquisa de doutorado. Tema: ANÁLISE DAS CONTRIBUIÇÕES DAS TIC À APRENDIZAGEM MATEMÁTICA DOS ALUNOS DAS ESCOLAS MUNICIPAIS DE CAMPINA GRANDE-PB. Desde já fico muito agradecido com a vossa colaboração.

\section{QUESTIONÁRIO PARA OS ALUNOS}

1- Como você se sente quando o professor usa as TIC nas aulas de matemática?

a)( ) Muito incentivado a estudar

b)( ) Quase sempre incentivado a estudar

c)( ) Às vezes incentivado a estudar

d)( ) Nunca incentivado a estudar

02- Como você ver as aulas de matemática quando o professor usa os recursos tecnológicos para ensinar os conteúdos?
a)( ) Muito mais atrativa
b)( ) Atrativa
c)( ) Às vezes atrativa
d)( ) Nunca atrativa

03- O professor tem usado muito as TIC para ensinar os conteúdos em sala de aula?
a)( ) Tem usado sempre
b)( ) Tem usado quase sempre
c)( ) Tem usado às vezes
d)( ) Nunca

04- As aulas de matemática se tornaram mais interessantes com o uso dos recursos tecnológicos pelo seu professor?

a)( ) Sempre 

b)( ) Quase sempre
c)( ) Às vezes
d)( ) Nunca
e)( ) Não uso estes recursos

05- As atividades de matemática ministradas por meios dos Recursos Tecnológicos têm melhorado seu desempenho no aprendizado dos conteúdos?
a)( ) Sempre
b)( ) Quase sempre
c)( ) Às vezes
d)( ) Nunca

06- Você se sente mais estimulado com o uso dos recursos tecnológicos no auxilio das atividades de matemática?
a)( ) Sempre
b)( ) Quase sempre
c)( ) Às vezes
d)( ) Nunca

07- Com a inclusão do uso da TIC nas aulas de matemáticas você tem percebido avanço no aprendizado?
a)( ) Sempre
b)( ) Quase sempre
c)( ) Às vezes
d)( ) Nunca

08- As aulas de matemática ficaram mais atraentes com o uso dos recursos tecnológico pelo seu professor (a)?
a)( ) Muito mais atraente
b)( ) Às vezes fica atraente
c)( ) Quase sempre atraentes
d)( ) Nunca

09- O professor sempre incentiva a classe usar mais as TIC para melhorar o aprendizado dos conteúdos de matemática?
a)( ) Incentiva muito.
b)( ) Incentiva sempre 
c)( ) Incentiva às vezes

d)( ) Nunca

10- O uso das TIC tem mudado seu interesse pelo aprendizado da disciplina de matemática?
a)( ) Mudou muito
b)( ) Mudou quase sempre
c)( ) Mudou às vezes
d)( ) Nunca 
Apêndices 05: Questionário aplicado aos professores.

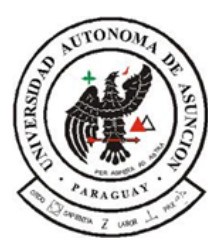

UNIVERSIDAD AUTONOMA DE ASUNCION - UAA

FACULTAD CIENCIAS JURÍDICAS, POLITICAS Y DE LA COMUNICACIÓN

DOCTORADO EN CIENCIAS DE LA EDUCACION

Prezado(a) Professor(a) venho pedir a vossa participação na minha pesquisa de doutorado. Tema: ANÁLISE DAS CONTRIBUIÇÕES DAS TIC À APRENDIZAGEM MATEMÁTICA DOS ALUNOS DAS ESCOLAS MUNICIPAIS DE CAMPINA

GRANDE-PB. Desde já agradeço a vossa participação.

\section{QUESTIONARIO PARA OS PROFESSORES}

1- Você tem conhecimento da potencialidade do uso das TIC no ensino dos conteúdos de matemática?
a)( ) Muito conhecimento.
b)( ) tenho conhecimento.
c)( ) Pouco conhecimento.
d)( ) Não tenho conhecimento.

2- $\quad$ As TIC possibilita potencialidade à pratica pedagógica no ensino-aprendizado de matemática favorecendo o rendimento acadêmico dos seus alunos?
a)( ) Possibilita muito
b)( ) Possibilita
c)( ) Possibilita pouco
d)( ) Não possibilita

3- Tem usado os recursos tecnológicos como apoio ao ensino-aprendizado nas aulas de matemática?
a) ( ) Tenho usado muito
b) ( ) Tenho usado
c) ( ) Tenho usado pouco
d) ( ) Não tenho usado

5- $\quad$ Tem notado a diferença no rendimento acadêmico dos seus alunos quando usa as TIC como apoio ao ensino-aprendizado dos conteúdos de matemática em sala de aula? 

a)( ) Melhora muito o rendimento
b)( ) Quase sempre melhora o rendimento
c)( ) Às vezes noto um melhor rendimento
d)( ) Nunca noto diferença no rendimento

6- $\quad$ A escola em que trabalha tem disponibilizado de laboratório de informática para você com seus alunos realizarem atividades usando os recursos tecnológicos?
a)( ) Tem disponibilizado muito
b)( ) Às vezes disponibiliza
c)( ) Não disponibiliza
d)( ) A escola não tem laboratório

7- $\quad$ O uso de aplicativos como jogos virtuais interativos: Desafio Matemático, Matemática para Crianças, Perguntas de Matemática, Caça Palavras Matemática etc. Nas aulas de matemática motivam os alunos a socializar conhecimentos entre si durante as aulas?
a)( ) Sempre
b)( ) Quase sempre
c)( ) Às vezes
d)( ) Nunca

8- $\quad$ Com o uso das TIC reforçando o aprendizado de matemática. Seus alunos tem melhorado o índice de aprovação na disciplina?
a)( ) Tem melhorado muito
b)( ) Tem melhorado quase sempre
c)( ) Tem melhorado às vezes
d)( ) Não tem melhorado

9- $\quad$ O uso das TIC tem dado mais dinamicidade as suas aulas tem levado os alunos a se interessarem mais pelo aprendizado dos conteúdos de matemática?
a)( ) Tem levado muito
b)( ) Tem levado quase sempre
c)( ) Tem levado às vezes
d)( ) Nunca

10- Você gostaria de ter mais capacitação relacionado ao uso das TIC para melhor desenvolver seu trabalho com os alunos em sala de aula? 

a)( ) Sempre
b)( ) Quase sempre
c)( ) Às vezes
d)( ) Nunca
e)( ) Não uso estes recursos 
Apêndices 06: Formulário de Validação dos Instrumentos da pesquisa.

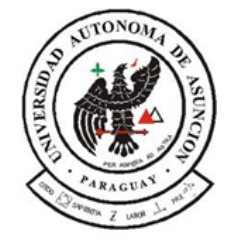

UNIVERSIDAD AUTONOMA DE ASUNCION - UAA

FACULTAD CIENCIAS JURÍDICAS, POLITICAS Y DE LA COMUNICACIÓN

DOCTORADO EN CIENCIAS DE LA EDUCACION

\section{FORMULÁRIO DE VALIDAÇÃo DE QUESTIONÁRIO}

Prezado (a) Professor (a),

Este formulário destina-se a validação do instrumento que será utilizado na coleta de dados da pesquisa de campo cujo tema é: ANÁLISE DAS CONTRIBUIÇÕES DAS TIC À APRENDIZAGEM MATEMÁTICA DOS ALUNOS DAS ESCOLAS MUNICIPAIS DE CAMPINA GRANDE-PB.

\section{FORMULÁRIO DE VALIDAÇÃo DE QUESTIONÁRIO PRÉ-TÉCNICA}

É uma validação dos instrumentos que serão utilizados na coleta de dados da pesquisa de campo;

Solicitamos sua análise no sentido de verificar se há coerência entre as questões formadas e os objetivos referentes a cada uma delas, além da clareza na construção dessas mesmas questões, correções adequadas em termos de conteúdo, relevância, ambiguidade, elaboração e outros aspectos considerados necessários para melhorar a apresentação e o conteúdo do questionário para a coleta de dados.

Com respeito aos enunciados de uma escala tipo LIKERT de 1 a 5 ; com os seguintes valores: 1- MUITO EM DESACORDO 2- EM DESACORDO 3- NEM DE ACORDO NEM EM DESACORDO 4- DE ACORDO 5- MUITO DE ACORDO - que devem ser assinaladas com (X). Sem mais para o momento 
antecipadamente agradeço por sua atenção e presteza em contribuir com o desenvolvimento de minha pesquisa.

Esta análise da adequação dos instrumentos aos objetivos da investigação vai ser validada através do julgamento de Doutores.

\section{VALIDADE DO INSTRUMENTO}

A análise da adequação dos instrumentos aos objetivos da investigação foi validada através do julgamento de __ (cinco) doutores na área de , do _, que atestaram a adequabilidade dos instrumentos para a presente pesquisa.

Esses profissionais tiveram a oportunidade de fazer as correções adequadas em termos de conteúdo, relevância, ambiguidade, elaboração e outros aspectos considerados necessários para melhorar a apresentação e o conteúdo do questionário para a coleta de dados.

A validade do conteúdo do instrumento foi expressa através dos seguintes questionamentos: Estão corretamente escritas as questões? As perguntas são expressões claras? As questões estão diretamente relacionadas com o tema? Será que o tipo e o tamanho da fonte são adequadas? É clara a intenção da aplicação do questionário? Há um número suficiente de itens do questionário em relação aos objetivos da pesquisa? Os itens do questionário são bem sequenciados? Tem instruções claras para responder as perguntas? O formato e a distribuição de itens são agradáveis aos olhos e motivadores para reação dos alunos pesquisados? Será que os itens satisfazem as regras de redação para a formulação de perguntas de um questionário? Apresenta várias opções de respostas ao item? Se evita abreviaturas, frases incompletas?

Marcando este procedimento, as observações e sugestões dos especialistas, sugeriram a adequabilidade dos instrumentos propostos.

$$
\text { Assunção (PY), __ de ___ de } 2018 .
$$




\section{Observações da Entrevista:}

\section{1- DADOS DO AVALIADOR}

Nome Completo:

Formação:

Instituição de Ensino:

Assinatura do Avaliador: 


\section{ANEXOS}

Foto 01: Laboratório de informática Escola Municipal Lafayete Cavalcante

Fonte: Elaboração própria.

Foto 02: Laboratório de informática Escola Municipal Lafayete Cavalcante.

Fonte: Elaboração própria. 
Foto 03: Sala de leitura Escola Municipal Lafayete Cavalcante.

Fonte: Elaboração própria.

Foto 04: Sala de leitura Escola Municipal Lafayete Cavalcante.

Fonte: Elaboração própria. 
Foto 05: Secretaria da Escola Manoel da Costa Cirne

Fonte: Elaboração própria.

Foto 06: Secretaria da Escola Manoel da Costa Cirne.

Fonte: Elaboração própria. 


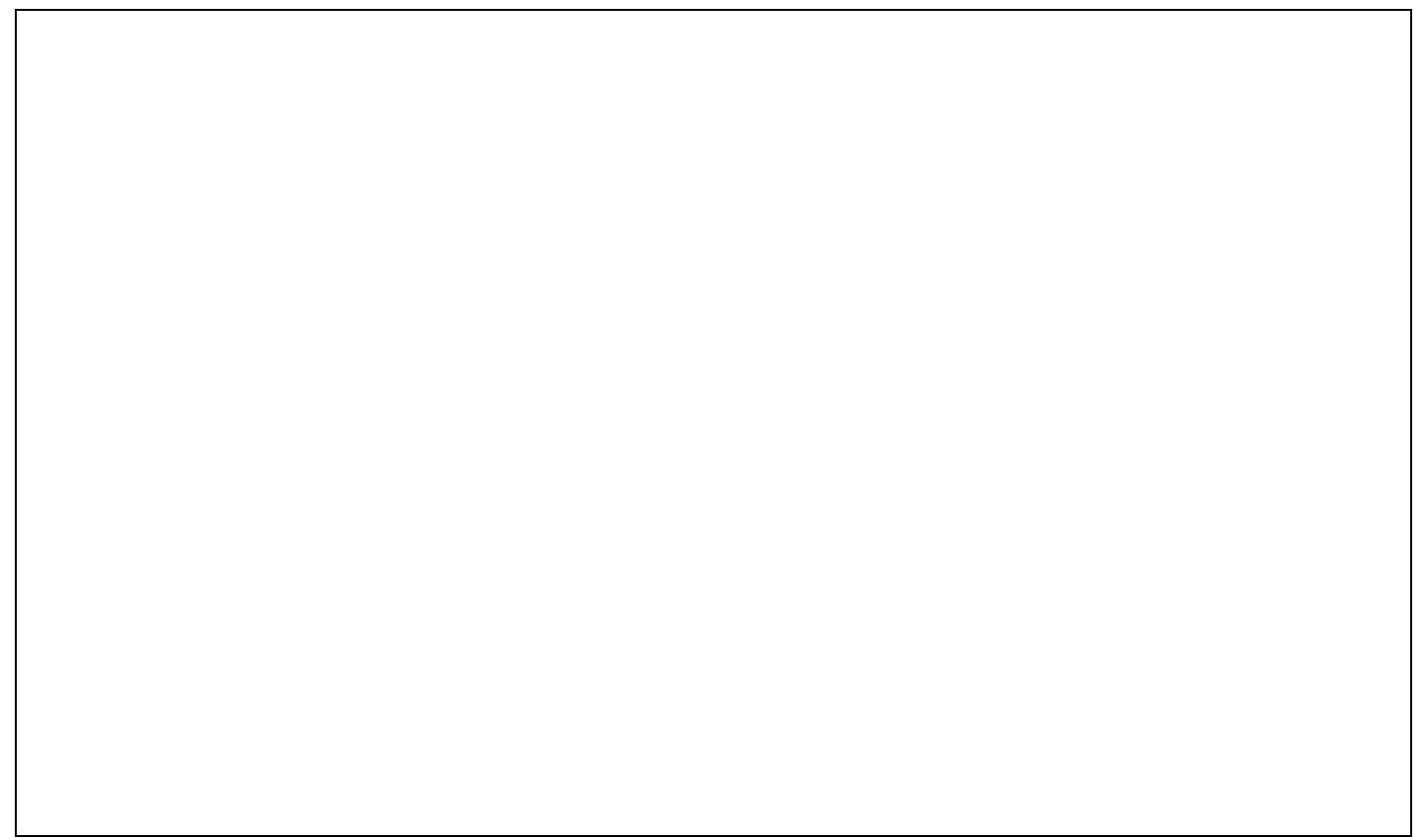

Foto 07: Sala de leitura Escola Municipal Manoel da Costa Cirne.

Fonte: Elaboração própria.

Foto 08: Sala de leitura Escola Municipal Manoel da Costa Cirne.

Fonte: Elaboração própria. 